UNIVERSIDADE DE SÃO PAULO

FACULDADE DE ECONOMIA, ADMINISTRAÇÃO E CONTABILIDADE DEPARTAMENTO DE ADMINISTRAÇÃO

PROGRAMA DE PÓS-GRADUAÇÃO EM ADMINISTRAÇÃO

Gestão do Capital Intelectual dos Programadores nas Indústrias de Software do Brasil e do Canadá

Heitor Siller Perez

Orientadora: Profa. Dra. Marisa Pereira Eboli

São Paulo 
Prof. Dr. João Grandino Rodas

Reitor da Universidade de São Paulo

Prof. Dr. Reinaldo Guerreiro

Diretor da Faculdade de Economia, Administração e Contabilidade

Prof. Dr. Adalberto Américo Fischmann

Chefe do Departamento de Administração

Prof. Dr. Lindolfo Galvão de Albuquerque

Coordenador do Programa de Pós-Graduação em Administração 
HEITOR SILLER PEREZ

\section{GESTÃO DO CAPITAL INTELECTUAL DOS PROGRAMADORES NAS INDÚSTRIAS DE SOFTWARE DO BRASIL E DO CANADÁ}

Dissertação apresentada ao Departamento de Administração da Universidade de São Paulo como requisito para a obtenção do título de Mestre em Administração

Orientadora: Profa. Dra. Marisa Pereira Eboli

\section{Versão Original}

SÃO PAULO 
FICHA CATALOGRÁFICA

Elaborada pela Seção de Processamento Técnico do SBD/FEA/USP

Perez, Heitor Siller
Gestão do capital intelectual dos programadores nas indústrias de
software do Brasil e do Canadá / Heitor Siller Perez. - São Paulo, 2011.
$192 \mathrm{p.}$
Dissertação (Mestrado) - Universidade de São Paulo, 2012.
Orientador: Marisa Pereira Eboli.
1. Capital intelectual 2. Softwares 3. Programadores I. Universidade
de São Paulo. Faculdade de Economia, Administração e Contabilidade.
II. Título.
CDD - 658.4038




\section{RESUMO}

Este estudo procura identificar, medir e avaliar as práticas dos empregadores do Brasil e do Canadá em relação à gestão do capital intelectual de seus desenvolvedores de software, comumente chamados de programadores.

O trabalho condensa, através da revisão e análise dos principais autores do assunto, os pressupostos básicos da boa gestão do capital intelectual. Tais pressupostos foram determinados especificamente para os desenvolvedores de software, que são agentes nucleares na indústria da tecnologia da informação, tecnologia essa que é onipresente em todas as instituições modernas.

A partir desses pressupostos básicos, foram definidos 13 Índices de Capital Intelectual, que possibilitaram a criação de um questionário eletrônico disponibilizado na internet, no qual profissionais do Brasil e do Canadá responderam após serem convidados através do disparo em massa de mensagens de e-mail, gerando assim os dados primários.

Os 13 Índices de Capital Intelectual propostos são: Índice de Instrução, Índice de Treinamento, Índice do Sistema de Conhecimento Organizacional, Índice Ocupacional, Índice de Satisfação, Índice Motivacional, Índice Vocacional, Índice de Coleguismo, Índice do Poder de Decisão (empowerment), Índice de Contato Direto com Clientes, Índice de Rotatividade, Índice Hierárquico e Índice do Papel Contábil.

Através de uma metodologia original proposta pelo autor, os resultados da pesquisa de campo, fartamente ilustrados com gráficos, mostraram que os respondentes do Canadá obtiveram melhor resultado em 7 índices, enquanto que os brasileiros superaram os canadenses nos demais 6 índices. 


\begin{abstract}
This study aims to identify, measure, and evaluate the practices of employers in Brazil and Canada in relation to the management of intellectual capital of its software developers, commonly called programmers.
\end{abstract}

The study condenses, through the review and analysis of the principal authors of the subject, the basic assumptions of the good management of intellectual capital. These assumptions were determined specifically for software developers, who are nuclear agents in the information technology industry, the technology that is omnipresent in all modern institutions.

From these basic assumptions, were defined 13 Intellectual Capital Indexes, which enabled the creation of an electronic questionnaire available on the Internet, in which professionals from Brazil and Canada responded after being invited through a mass e-mail sending, generating the primary data.

The 13 Intellectual Capital Indexes proposed are: Education Index, Training Index, Organizational Knowledge System Index, Occupational Index, Satisfaction Index, Motivational Index, Vocational Index, Comradeship Index, Empowerment Index, Index of Direct Contact with Customers, Turnover Index, Hierarchical Index, and Accounting Role Index.

Using an original methodology proposed by the author, the results of field research, fully illustrated with charts, showed that respondents in Canada obtained better results in 7 indexes, while the Brazilians beat the Canadians in the other 6 indexes. 
SUMÁRIO

RESUMO

.iii

ABSTRACT.

v

LISTA DE TABELAS

4

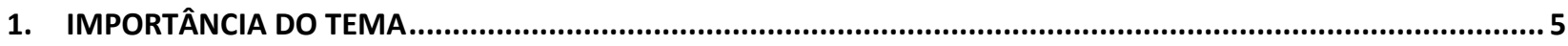

2. PROBLEMA, OBJETIVOS E ASPECTOS METODOLÓGICOS GERAIS DE PESQUISA ..................... 11

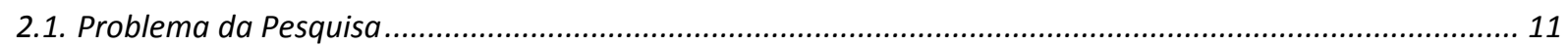

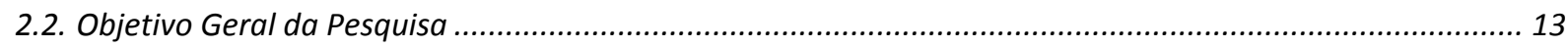

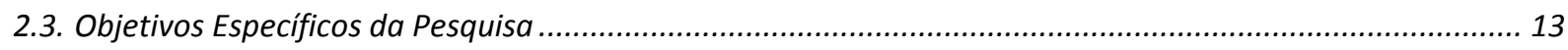

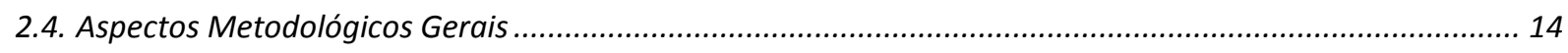

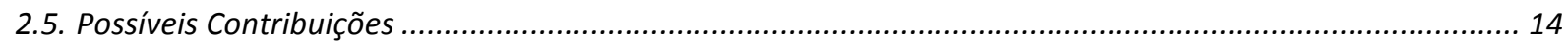

3. O SETOR PRODUTOR DE SOFTWARE DO BRASIL E DO CANADÁ ...................................................15

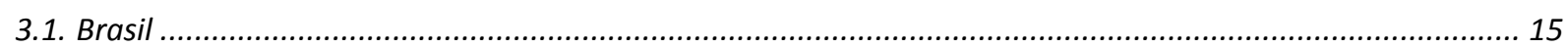

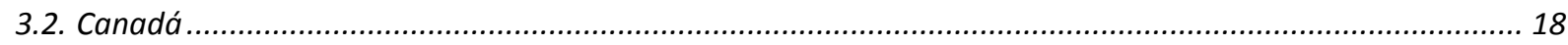

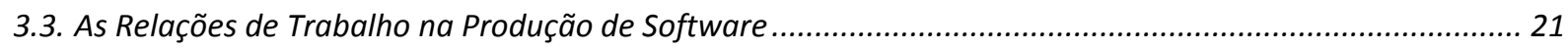

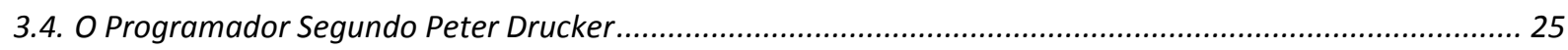

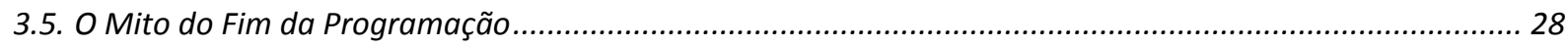

3.6. O Processo Errático Clássico no Desenvolvimento de Softwares ......................................................... 30

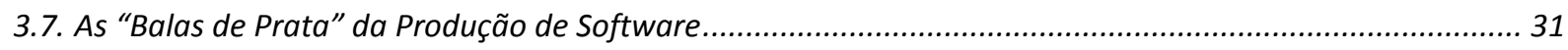

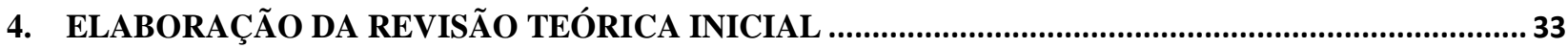

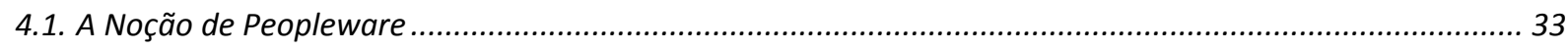

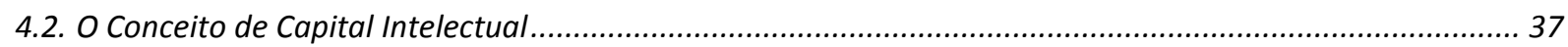

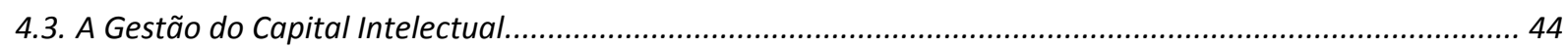

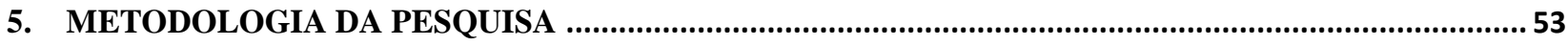

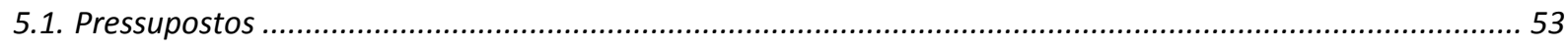




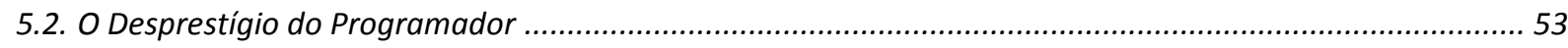

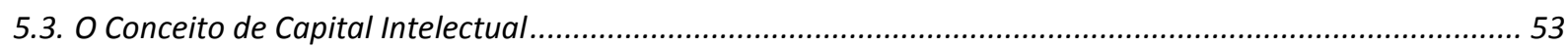

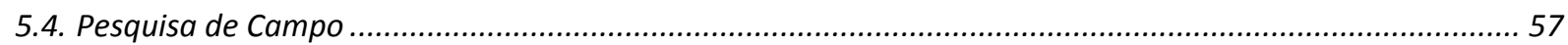

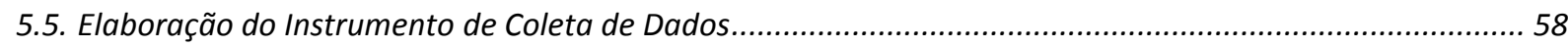

6. APRESENTAÇÃO E ANÁLISE DOS DADOS COLETADOS ..........................................................63

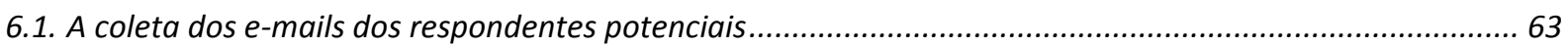

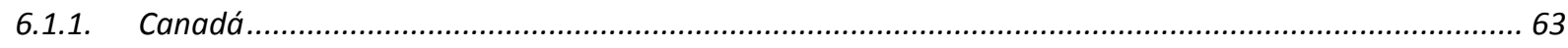

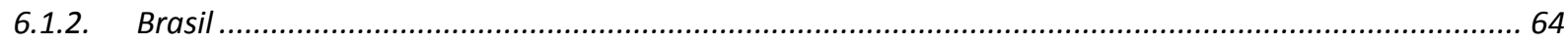

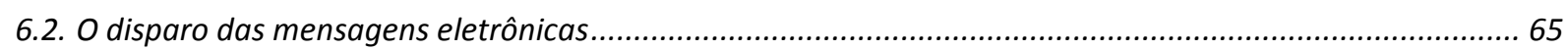

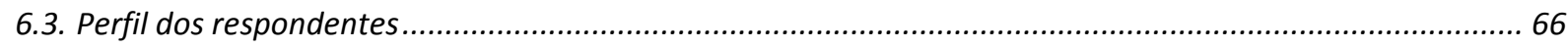

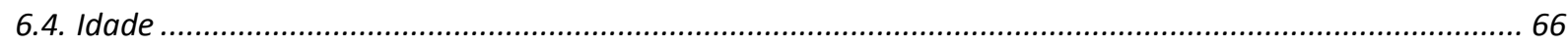

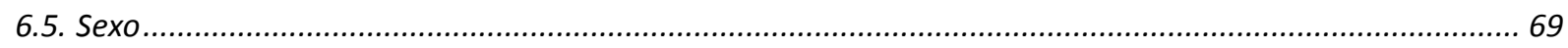

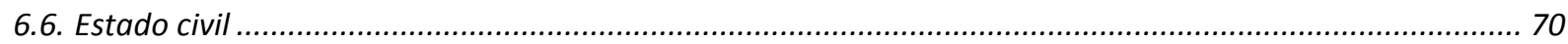

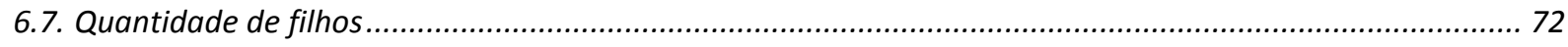

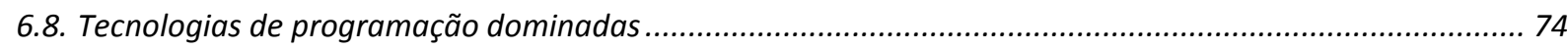

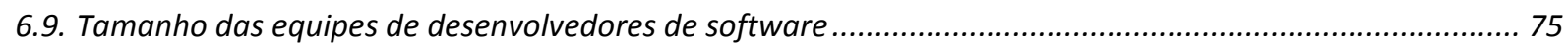

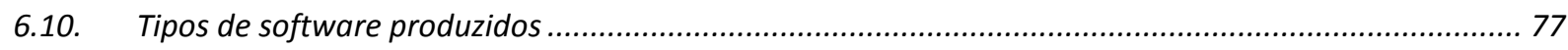

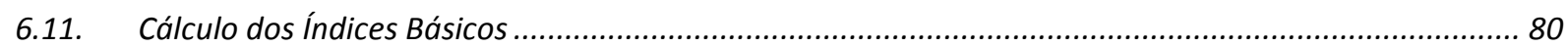

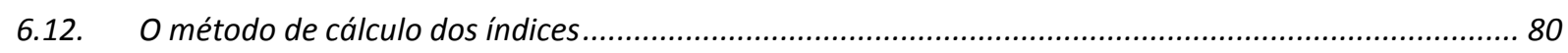

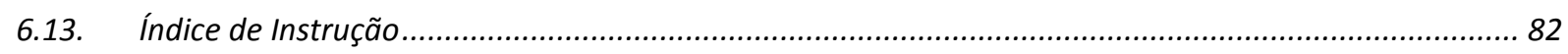

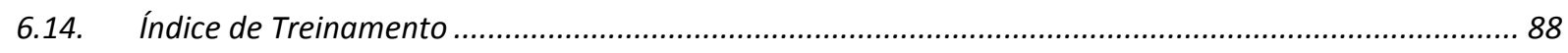

6.15. Índice do Sistema de Conhecimento Organizacional ....................................................................... 93

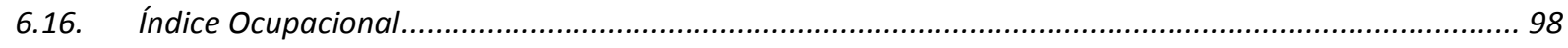

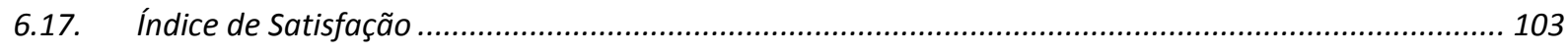

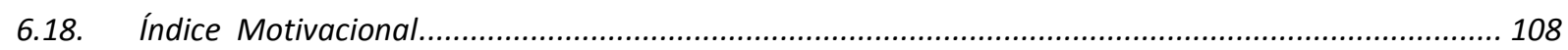

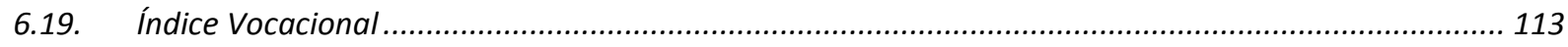

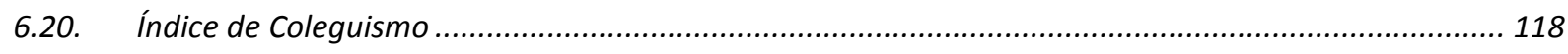


6.21. Índice de Poder de Decisão (empowerment) ....................................................................... 123

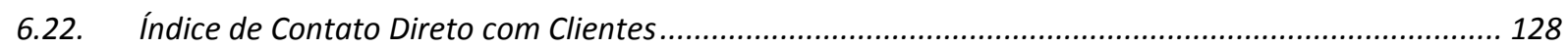

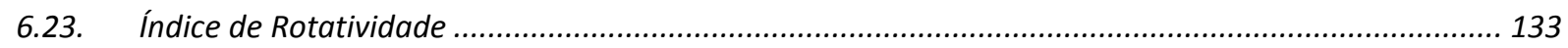

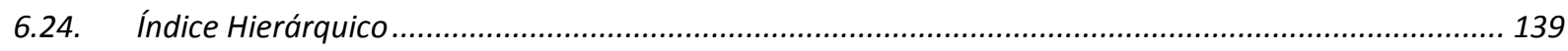

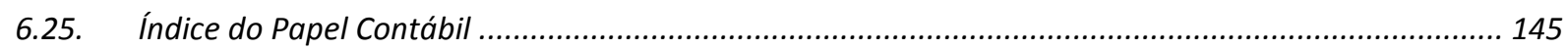

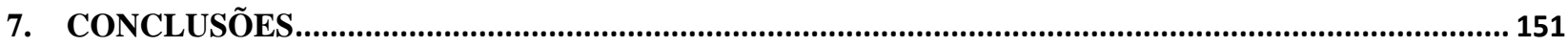

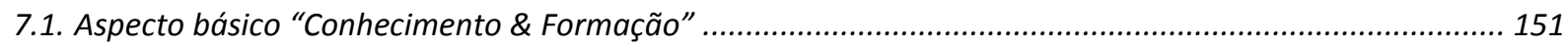

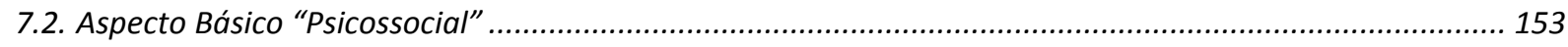

7.3. Aspecto Básico "Relações de Trabalho \& Poder" ........................................................................................ 155

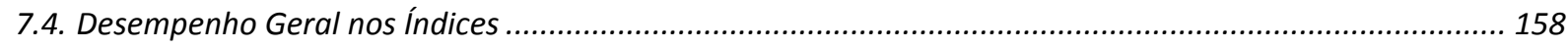

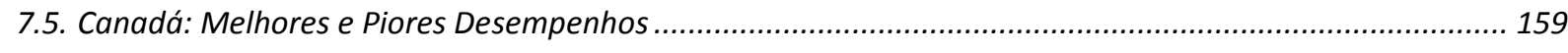

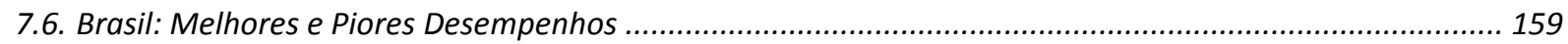

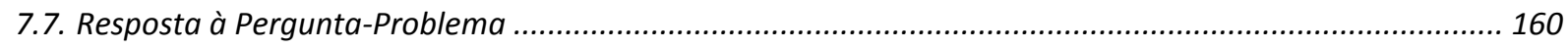

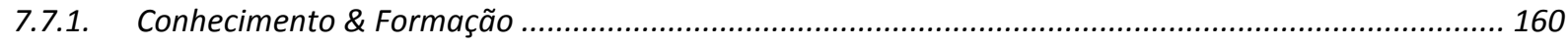

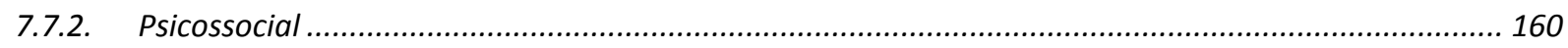

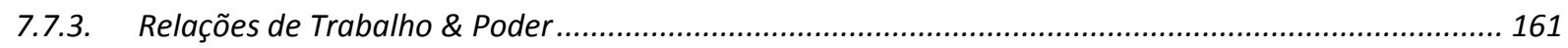

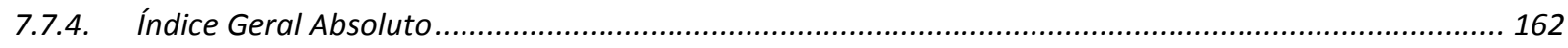

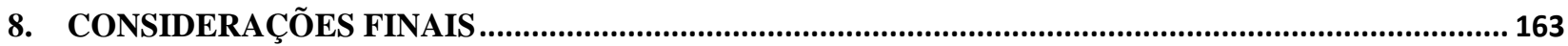

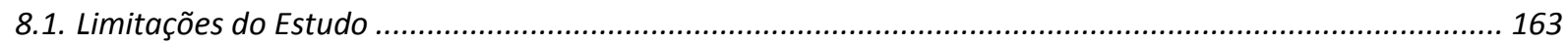

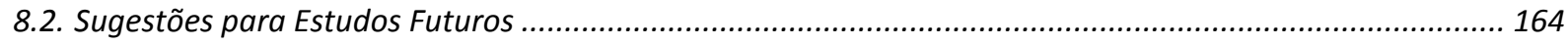

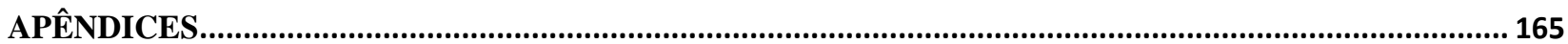

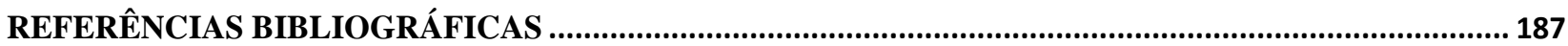




\section{LISTA DE TABELAS}

Tabela 1 - O setor de software brasileiro ............................................................ 17

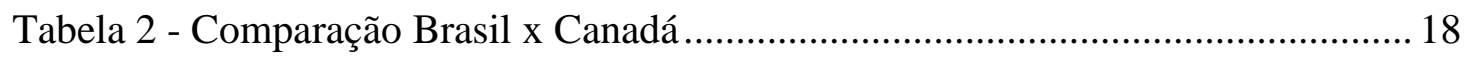

Tabela 3 - O conceito de capital intelectual e seus pressupostos ............................... 51

Tabela 4 - Elaboração do Instrumento de Coleta ...................................................... 59

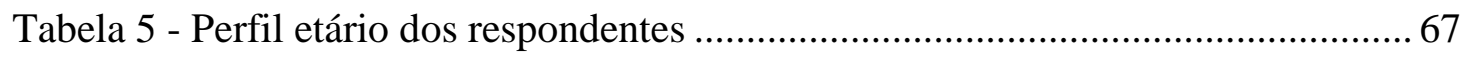

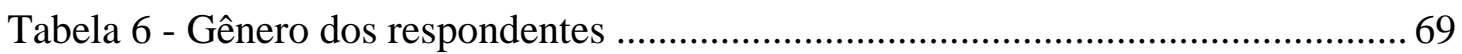

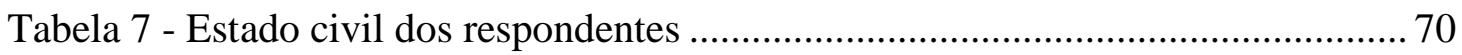

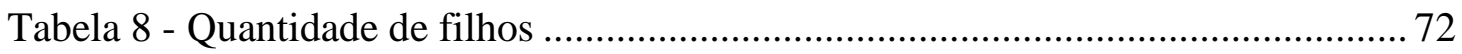

Tabela 9 - Linguagens de programação dominadas .................................................... 74

Tabela 10 - Tamanho das equipes de desenvolvedores de software ........................... 75

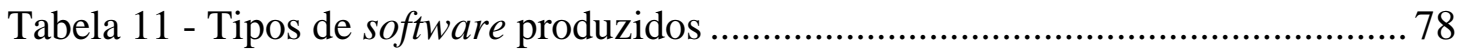

Tabela 12 - Índice de Instrução - primeira questão ................................................... 84

Tabela 13 - Índice de Instrução - segunda questão .................................................... 86

Tabela 14 - Índice de Treinamento - primeira assertiva............................................ 89

Tabela 15 - Índice do Sist. de Conhecimento Organizac. - segunda assertiva............. 96

Tabela 16 - Comparação Geral dos Índices - Conhecimento \& Formação ................ 152

Tabela 17 - Comparação Geral dos Índices - Psicossocial....................................... 154

Tabela 18 - Comparação Geral dos Índices - Relações de Trabalho \& Poder ............ 156

Tabela 19 - Desempenhos superiores nos Índices de Capital Intelectual, por país ... 158 


\section{IMPORTÂNCIA DO TEMA}

A tecnologia da informação (TI) é indiscutivelmente vital na gestão das instituições de todos os tipos, no Brasil e no mundo. Segundo YOURDON (1995), "a tecnologia de informação de uma empresa é seu calcanhar-de-aquiles". Para BROOKING (1997 p.79), a estrutura de tecnologia da informação é a espinha dorsal de uma corporação. O processo de surgimento e disseminação dos microcomputadores pessoais (PCs) a partir da década de 1980, somado ao surgimento e disseminação da Internet a partir da década de 1990, revolucionou o mundo moderno, derrubando paradigmas e expandindo exponencialmente as possibilidades de comunicação e interação humanas ROBBINS (2005).

As instituições e a população brasileiras são muito informatizadas. Segundo a PNAD 2007 (Pesquisa Nacional por Amostra de Domicílio, feita pelo IBGE - Instituto Brasileiro de Geografia e Estatística), 26,5\% das famílias brasileiras têm computador, e os bancos brasileiros estão entre os mais informatizados do mundo. Todos os bancos múltiplos em operação no Brasil possuem websites (Internet banking) nos quais os seus clientes podem executar uma vasta gama de operações bancárias, sem a necessidade de se dirigir ou telefonar a uma agência física.

O comércio eletrônico no Brasil é uma realidade, sendo que seu menor crescimento anual na década 2000-2009 foi de $28 \%$ e o maior, $76 \%$. Em 2009, o faturamento total foi de $\mathrm{R} \$ 10,6$ bilhões E-BIT (2010). Grande parte das redes varejistas de supermercados e eletrodomésticos vendem pela internet, e todos os grandes meios de comunicação estão presentes na grande rede, fornecendo grande variedade de informações na forma escrita, além de muitas imagens e vídeos, inclusive com transmissões ao vivo.

Basicamente há dois tipos de softwares: os softwares proprietários, fornecidos principalmente por grandes multinacionais tais como IBM, SAP e Microsoft, e os softwares sob medida, desenvolvidos especificamente para a própria empresa que os utilizará.

Os softwares proprietários são caracterizados por serem mais genéricos e menos suscetíveis a personalizações, isto é, o mesmo software é usado nos mais variados tipos de instituições. Entre os mais conhecidos e usados nas últimas décadas estão o Microsoft 
Windows e o Microsoft Excel. Já os softwares sob medida são mais especializados, por serem projetados sob medida para determinada instituição

É no entanto fundamental destacar que esses dois tipos básicos de software são conceituais, pois há softwares de sucesso no mercado que mesclam características de ambos os tipos. Pode-se citar como exemplo dessa não-dicotomia os softwares produzidos pela empresa SAP, que são proprietários porém possuem uma grande gama de módulos vendidos separadamente, que acabam por permitir certa medida de personalização de acordo com a instituição que o adquire. Do mesmo modo, há softwares sob medida que, pelo fato de usarem ferramentas de programação proprietárias, acabam tendo sua capacidade de personalização limitada.

É consenso que a internet veio para ficar, assim como vieram para ficar as tecnologias de comunicação em massa como o rádio, o telefone e a televisão. Segundo ROBBINS (2005):

"No início do século $X X$, o telefone reduziu radicalmente a comunicação pessoal face a face. A popularização das copiadoras, no final da década de 1960, foi o tiro de misericórdia no papel-carbono (...). Desde o começo da década de 1980, estamos sendo alvos de novas tecnologias eletrônicas, que vêm remodelando amplamente a forma de comunicação nas organizações".

Os websites, que se confundem com a própria noção de internet, surgiram no início da década de 1990, quando a microcomputação em massa já era realidade e, portanto, a produção de softwares stand-alones, isto é, softwares que são instalados diretamente no computador que o utiliza, já estava razoavelmente amadurecida. Após os primeiros anos da internet, os websites foram se tornando mais poderosos e complexos, e se transformaram de simples páginas estáticas em um novo tipo de software, que são os sistemas para a web. Os sistemas para a web são na verdade websites dinâmicos e complexos, executados de dentro do navegador (browser). Eles não estão instalados no computador que o utiliza, e podem executar as mais diversas tarefas. A diferença fundamental desse novo tipo de software é que eles podem ser acessados de qualquer computador que esteja conectado à internet, derrubando assim as barreiras física e geográfica de um software stand-alone, que está fisicamente preso ao microcomputador em que estiver instalado. 
O programador é o agente central na atividade de produzir softwares. No presente trabalho, o conceito de programador é o profissional que acumula simultaneamente as funções de análise e codificação, cargo que no mercado de trabalho é comumente chamado de "analista programador". É fundamental esclarecer que existe no mercado o cargo chamado “analista de sistemas" e, mais raro, o cargo chamado "programador". No entanto, não é possível se construir um software, por mais simples e trivial que seja, somente com um “analista de sistemas" ou somente com um "programador". Do mesmo modo, não é possível se construir um edifício somente com engenheiros, ou somente com pedreiros. Entretanto, diferentemente de edifícios, a construção de um software exige alta qualificação técnica em ambas as funções (o que não é o caso do cargo de pedreiro, no qual predomina o esforço braçal).

A respeito do papel central do analista programador, STAIR \& REYNOLDS (2009) citam:

"O analista de sistemas é uma peça fundamental na equipe de desenvolvimento e é, com freqüência, a única pessoa que vê o sistema em sua totalidade. (...) [Ele é um] indivíduo que geralmente é considerado um facilitador, moderador, negociador $e$ intérprete das atividades de desenvolvimento."

É notável o fato de que o analista programador, que no presente trabalho é denominado simplesmente como programador, é freqüentemente a única pessoa que pode enxergar o sistema como um todo. Essa perspectiva privilegiada lhe é conferida pelo fato de que o processo natural de desenvolvimento de um software assim o exige, já que um sistema empresarial serve exatamente para controlar e integrar todas as pessoas e divisões integrantes de um determinado processo administrativo. Dessa forma, torna-se automaticamente necessária a comunicação dos programadores com todas as áreas da empresa, conforme ilustrado na figura a seguir: 
Figura 1 - O papel nuclear do programador/analista

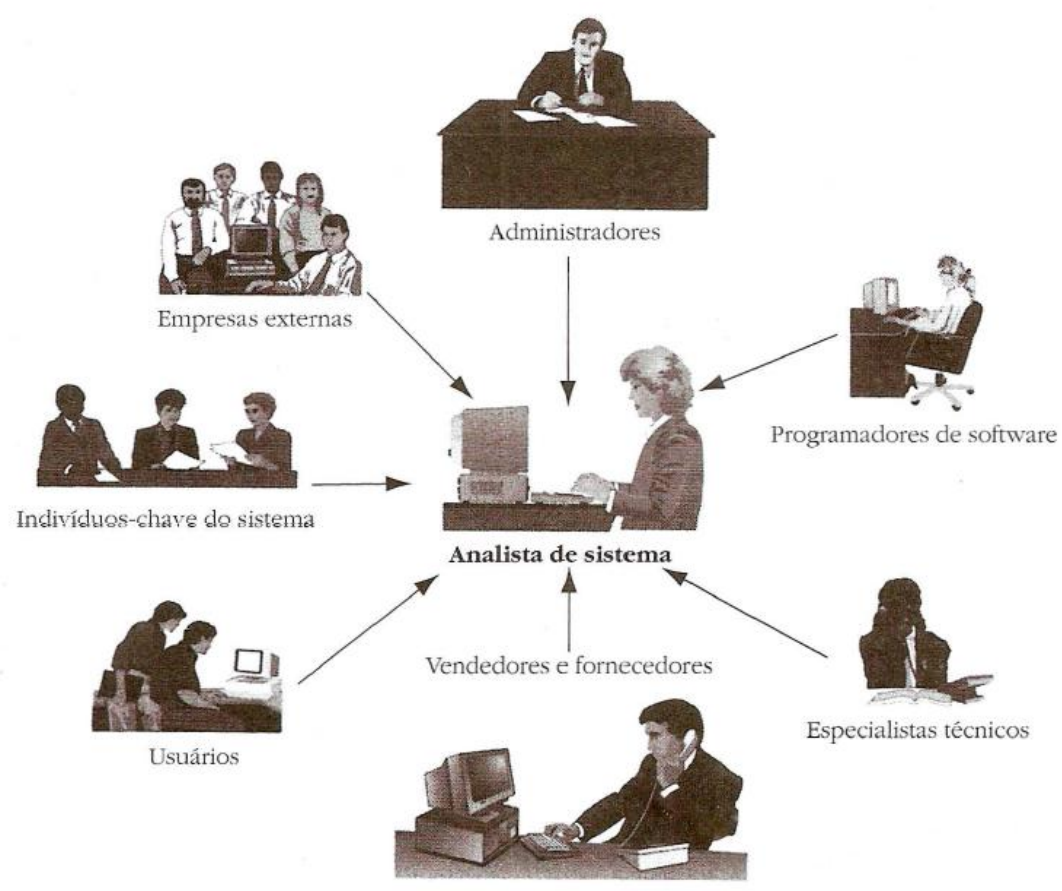

Fonte: STAIR \& REYNOLDS (2009)

A produção de um software é um processo amplo, que sem dúvida demanda profissionais das mais diversas áreas. No entanto, o foco do presente trabalho é no protagonismo do programador, devido ao seu papel claramente nuclear no processo. Conforme YOURDON (1995), “as pessoas que constroem esses sistemas de informação - os programadores, analistas de sistemas, projetistas de bancos de dados, especialistas em telecomunicações e outros - desempenham um papel cada vez mais crucial na saúde fiscal e na própria sobrevivência de seus empregadores”. A grande questão não é em que grau de importância está a função do programador dentro do processo, mas sim se as condições mínimas para que o programador execute um trabalho de excelência existem. Sendo assim, as questões que precisam ser respondidas são:

- Os aspectos humanos dos programadores estão sendo identificados e plenamente considerados nas tomadas de decisões da instituição?

- Existem programadores entre os tomadores de decisões da indústria de software? 
- Existem na instituição condições mínimas para a excelência do programador? Quais são essas condições mínimas? 


\section{PROBLEMA, OBJETIVOS E ASPECTOS METODOLÓGICOS GERAIS DE PESQUISA}

\subsection{Problema da Pesquisa}

A minha trajetória estudantil e profissional como idealizador, projetista, criador, mantenedor e programador de softwares me fez vivenciar amplos aspectos da profissão de programador em geral. Essa experiência, somada à minha outra formação acadêmicoprofissional de administrador, me possibilitou complementar e enriquecer meus pensamentos e reflexões a respeito desse fundamental setor econômico no Brasil e no mundo, o setor da tecnologia da informação (TI).

As grandes inquietações são a fonte motivacional para a pesquisa científica. No meu caso, a inquietação que motivou o presente trabalho surgiu de uma percepção de que agentes nucleares e fundamentais na produção de softwares são marginalizados no mercado de trabalho e dentro das empresas produtoras de software, e acabam sendo tratados como meras peças intercambiáveis e de fácil substituição. Como dito em DE MARCO \& LISTER (1999):

"A maioria de nós gestores é propensa a um erro particular: a tendência de gerir pessoas como se fossem componentes modulares (...). Os módulos que construímos possuem a característica de uma caixa-preta, então suas idiossincrasias internas podem ser seguramente ignoradas. Eles foram desenhados para serem usados com uma interface padrão. Após anos confiando nesses métodos modulares (...) nós procuramos gerir os recursos humanos da mesma forma modular".

Ora, a simples comparação entre as palavras núcleo e margem, de semânticas opostas, expõe de forma simples e contundente a contradição fundamental da inquietação básica que motivou o presente trabalho científico. 
Além disso, há um outro fundamental e contundente aspecto que tornou a minha inquietação ainda maior e extraordinária o suficiente para torná-la o objeto de investigação científica de minha dissertação de mestrado: É inviável pensar que a partir do século XXI seja possível que as instituições, de todos os portes, nacionalidades e setores econômicos, possam manter funcionando seus processos sem o uso freqüente e intensivo da tecnologia da informação.

Ora, se se entende que os agentes centrais, de um setor central da economia moderna, estão tendo seus capitais intelectuais mal administrados, o que pode ser mais importante de ser estudado? O problema da pesquisa então é um problema de suma importância, pois afeta a tudo e a todos que vivem em sociedades civis minimamente organizadas.

No intuito de enriquecer a investigação científica do assunto em questão, decidiu-se realizar uma pesquisa de campo no Brasil e no Canadá. Entende-se que tal internacionalização tem o potencial de trazer relevantes vantagens, pois possibilita uma comparação entre países em estágios de desenvolvimento econômico-social distintos e, em vários aspectos, extremamente opostos. Ao mesmo tempo, há semelhanças entre ambos países, como a idade, o tamanho do território, a abundância de determinados recursos naturais e mesmo uma posição de coadjuvância no mundo globalizado. Somado a isso, a escolha do Canadá como país simultaneamente pesquisado junto com o Brasil foi incentivada pela oportunidade que tive, durante o curso de mestrado, de participar de intercâmbio acadêmico na cidade de Montreal. Apoiado por bolsa do governo canadense, pude ter contato direto com o clima, os idiomas, a economia e a cultura daquele país.

A partir do exposto acima, define-se portanto a pergunta-problema da pesquisa: As práticas atuais de gestão do capital intelectual dos programadores nas indústrias brasileira e canadense de software contribuem para a excelência técnica e para a valorização do profissional programador? 


\subsection{Objetivo Geral da Pesquisa}

Identificar, descrever, analisar e comparar os padrões das práticas de gestão do capital intelectual dos programadores nas indústrias brasileira e canadense de software.

\subsection{Objetivos Específicos da Pesquisa}

- Criar uma metodologia de medição, identificação e análise do capital intelectual nas instituições, através da definição e do cálculo de índices baseados diretamente no referencial teórico consultado e revisado.

- Construir instrumento de coleta de dados e verificar sua efetividade em captar os padrões das práticas de gestão do capital intelectual dos programadores nas indústrias brasileira e canadense de software.

- Comparar diretamente as indústrias brasileira e canadense de software, através de índices específicos ao conceito de capital intelectual.

- Apontar possíveis contradições entre as práticas de gestão do capital intelectual dos programadores, nas indústrias brasileira e canadense de software, e a teoria estudada a respeito de capital intelectual. 


\subsection{Aspectos Metodológicos Gerais}

Para atingir os objetivos propostos neste trabalho, os temas foram organizados da seguinte maneira:

- O setor produtor de software no Brasil e no Canadá

- O que é capital intelectual - conceito, gestão e principais idéias críticas e desafios.

- Definição de índices de capital intelectual

- Elaboração de instrumento de coleta

- Pesquisa de campo no Brasil e no Canadá

- Análise dos dados coletados, a partir da revisão teórica e das idéias discutidas

\subsection{Possíveis Contribuições}

A expectativa principal é que a pesquisa possa contribuir para o progresso dos processos e práticas da indústria brasileira de softwares, no sentido de se alcançar a excelência técnica e potencializar a competitividade global do setor.

Como já dito, o programador é o agente nuclear no processo de produção de softwares, e cada vez mais as instituições, de todos os portes, setores e regiões do planeta dependem da tecnologia da informação para sustentarem seus processos internos e externos.

Esperamos assim colaborar, usando-se uma comparação entre Brasil e Canadá, para o aperfeiçoamento de um setor econômico tão fundamental como a tecnologia da informação, através de um enfoque voltado para os conhecimentos e capacidades intelectuais das pessoas mais diretamente envolvidas no processo de produção de softwares, isto é, os programadores. 


\section{O SETOR PRODUTOR DE SOFTWARE DO BRASIL E DO CANADÁ}

\subsection{Brasil}

Em SOFTEX (2009), temos diversos dados sobre o setor produtor de software no Brasil e no mundo. A publicação divide o setor em dois grandes grupos, um sendo o setor no qual a produção de softwares e de serviços em tecnologia da informação é a atividade principal da empresa, chamado de IBSS, e o outro sendo o conjunto de empresas nas quais a produção em tecnologia da informação é uma atividade secundária e complementar às suas atividadeschave, chamado de NIBSS. O estudo dividiu as empresas em 7 grupos, de acordo com sua atividade principal dentro do setor de tecnologia da informação. Como o presente estudo se foca basicamente em software, os dados selecionados se referem a apenas 5 destes grupos, sejam eles:

1. Desenvolvimento e edição de software pronto para uso: são as empresas que planejam e desenvolvem internamente softwares proprietários, que são vendidos como soluções prontas.

2. Desenvolvimento de software sob encomenda e outras consultorias em software: são empresas que têm como atividade principal desenvolver softwares sob medida, de acordo com as necessidades e exigências de seus clientes.

3. Processamento de dados: são empresas que fornecem serviços computacionais tais como serviços de entrada de dados (escaneamento de documentos), tratamento de dados e gestão e operação de equipamentos de processamento de dados de terceiros.

4. Atividades de banco de dados e distribuição on-line de conteúdo eletrônico: empresas que vendem serviços de banco de dados tais como armazenamento, acesso e edição de banco de dados, além de fornecedores de conteúdo tais como portais, sites de busca, sites de jogos e entretenimento e também livros eletrônicos e afins. 
5. Outras atividades de informática: engloba empresas que fornecem serviços de instalação de softwares e de recuperação de panes informáticas, além de outras atividades relacionadas à informática, não especificadas nos demais grupos utilizados na publicação.

Sendo assim, os 2 grupos remanescentes, "consultoria em hardware" e "manutenção e reparação de máquinas de escritório e de informática" não são considerados, pois não tratam de software. Vejamos, portanto, alguns dados que dão uma visão geral do setor de software brasileiro: 
Tabela 1 - O setor de software brasileiro

\begin{tabular}{|c|c|}
\hline \multicolumn{2}{|c|}{ Brasil - Setor de Software } \\
\hline Número de Empresas: & 43.000 \\
\hline $\begin{array}{l}\text { Número de trabalhadores/empresa } \\
\qquad(2005) \text { : }\end{array}$ & $\begin{array}{l}\text { - Até } 9 \text { trabalhadores: } 92 \% \\
\text { - Dez ou mais trabalhadores: } 8 \%\end{array}$ \\
\hline Origem do capital: & $\begin{array}{l}\text { - Privado: } 99 \% \\
\text { - Público: } 1 \%\end{array}$ \\
\hline Receita Líquida (2005): & $\begin{array}{l}\text { - Total: } \mathrm{R} \$ 25 \text { bilhões } \\
\text { - Advindas do exterior: } \mathrm{R} \$ 0,7 \\
\text { bilhões (3\% do total) }\end{array}$ \\
\hline $\begin{array}{l}\text { Gastos com pessoal (sócios e } \\
\text { assalariados - 2006) }\end{array}$ & $38 \%$ da receita líquida \\
\hline
\end{tabular}

Fonte: o autor, adaptado de SOFTEX (2009)

Um ponto a se destacar é a grande concentração (92\%) de trabalhadores atuando em empresas muito pequenas ( 9 ou menos trabalhadores). 


\subsection{Canadá}

A pesquisa em SOFTEX (2009) faz diversas comparações entre países, baseando-se na tecnologia da informação. Vejamos então alguns dados selecionados de Brasil e Canadá, que comparam os dois países objetos do presente estudo:

Tabela 2 - Comparação Brasil x Canadá

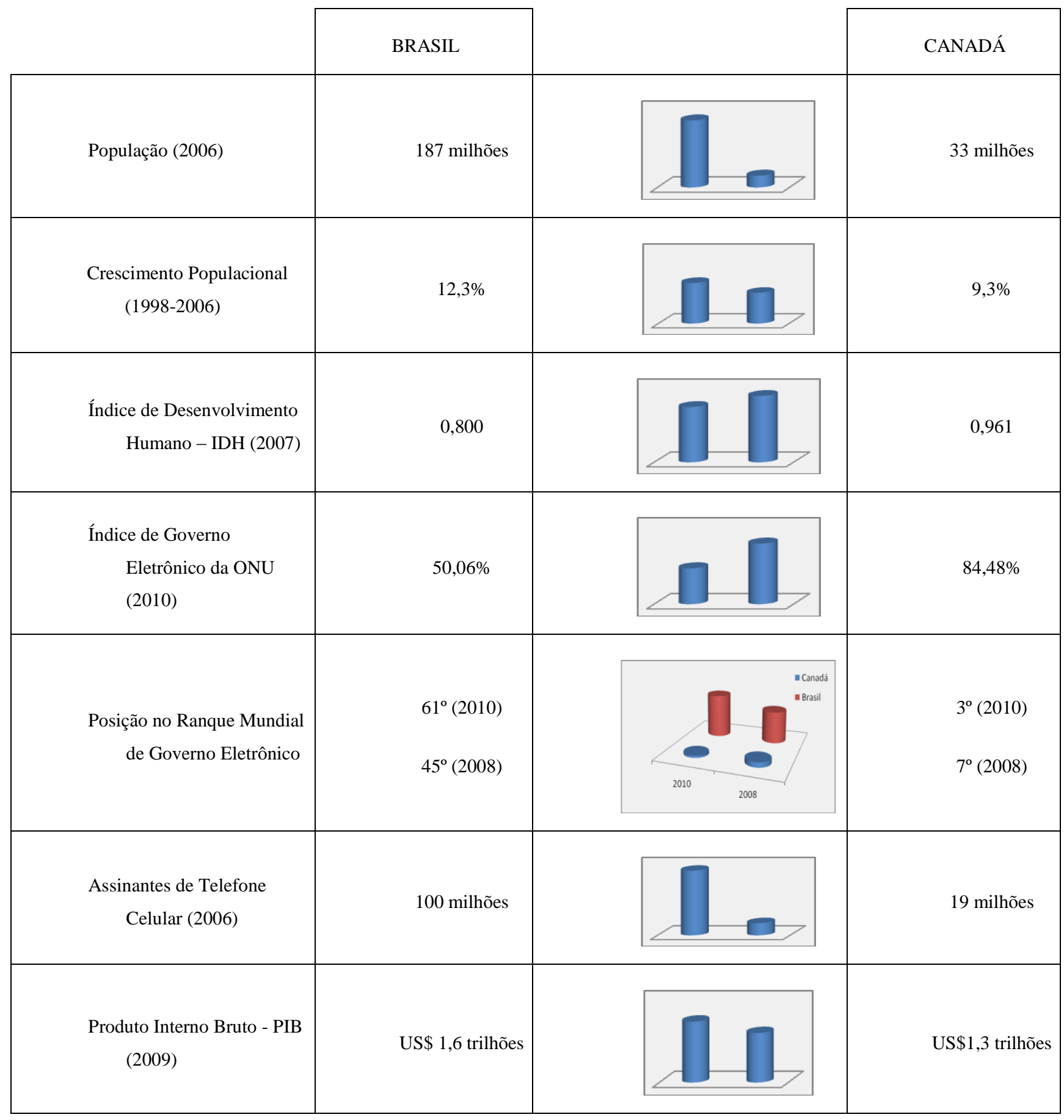




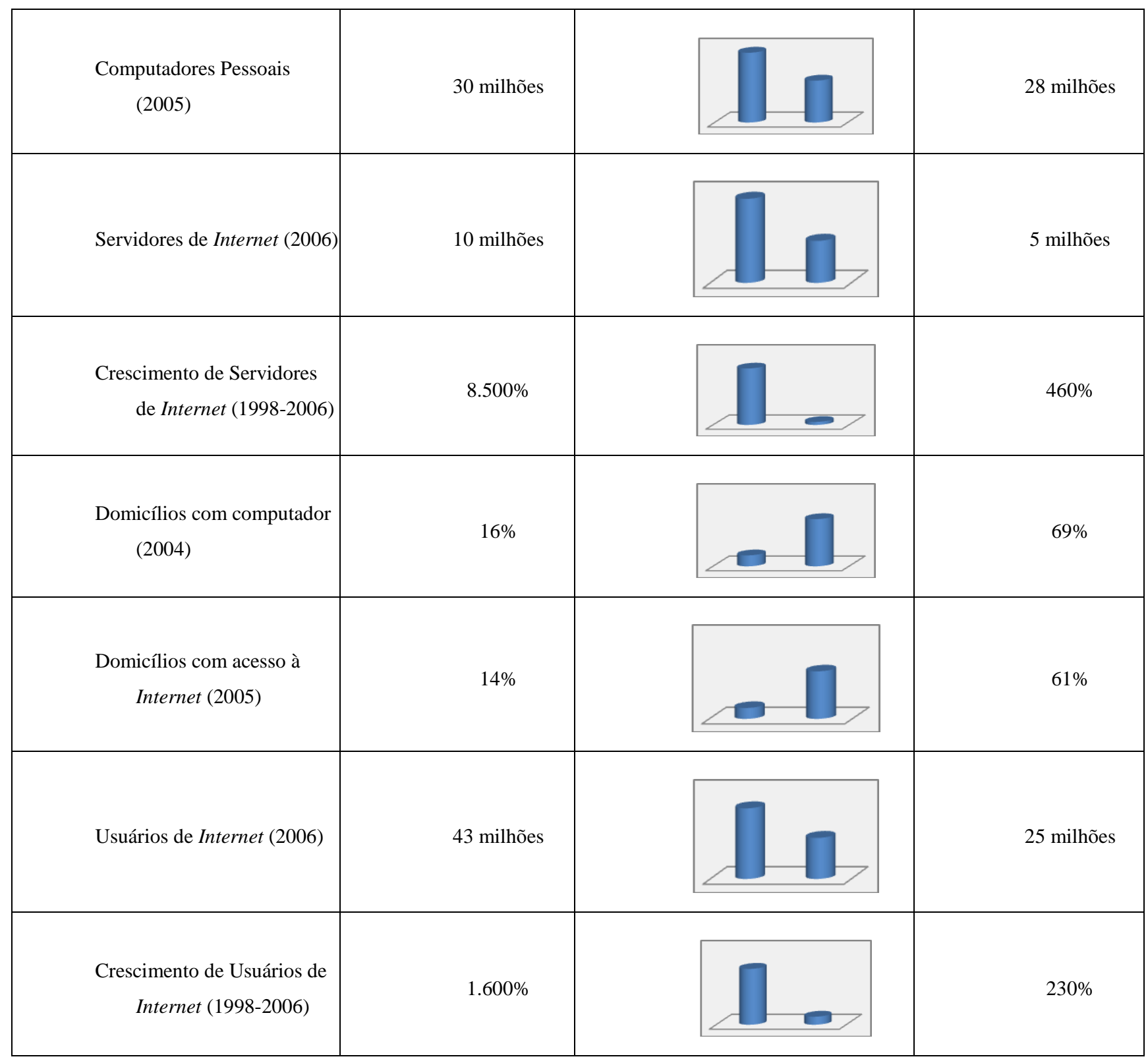

Fonte: o autor, organizado a partir de SOFTEX (2009) e UNPAN (2011)

Com relação ao Índice de Governo Eletrônico (e-Government) e seus respectivos ranques mundiais de nações, UNPAN (2011) define Governo Eletrônico como a capacidade e a disposição do setor público em implantar a tecnologia da informação e da comunicação (TIC) para melhorar o conhecimento e informação ao serviço do cidadão. A metodologia de cálculo dos índices de cada país engloba aspectos básicos como 
capacidade financeira, infraestrutura, capital humano e das capacidades reguladora, administrativa e sistêmica do Estado.

Segundo a publicação, a estrutura conceitual básica do conceito de Governo Eletrônico está associada ao que chamam de paradigma do desenvolvimento humano e social. No entendimento da ONU (Organização das Nações Unidas), que produz tais índices a partir de pesquisa em nível global, o nível de desenvolvimento de Governo Eletrônico de um país é uma função de três fatores fundamentais, sejam eles: os recursos atuais, a infraestrutura de tecnologia da informação e da comunicação disponível e o nível de desenvolvimento dos recursos humanos. Além disso, leva-se em conta se todas as iniciativas de Governo Eletrônico são abrangentes ou se estão disponíveis somente uns poucos privilegiados.

Em síntese, os dados comparativos entre os dois países mostram algumas semelhanças, como o PIB e o número de computadores pessoais, e também grandes disparidades, com destaque para a população mais de 5 vezes maior do Brasil, e para as taxas de crescimento no consumo de produtos da tecnologia da informação, muito maiores no Brasil. Também se destaca a grande superioridade do Canadá em relação ao Índice de Desenvolvimento Humano. 


\subsection{As Relações de Trabalho na Produção de Software}

Os conflitos nas relações de trabalho do programador de softwares é o foco do presente trabalho. Sendo assim, cabe uma discussão mais aprofundada do tema. NOGUEIRA (2008) define as relações de trabalho como:

"As relações de trabalho são entendidas enquanto arranjos coletivos formais $e$ informais entre capital e trabalho, que produzem definições estáveis e instáveis dos salários e da remuneração, da jornada de trabalho, do contrato de trabalho, das condições de trabalho, saúde e de ocupação, das formas de organização do processo de trabalho, das formas de participação $e$ negociação dos trabalhadores e da organização sindical".

Em sua discussão acerca de uma perspectiva de gestão na qual as relações de trabalho são consideradas como estratégicas para a sobrevivência das organizações, o autor propõe uma série de ações a serem executadas, no sentido de se diagnosticar as relações de trabalho. Concernente aos objetivos do presente trabalho de pesquisa, foram selecionados os seguintes:

- Verificar o padrão das condições de trabalho comparativamente ao mercado;

- Comparar salários e benefícios adotados pela empresa em relação ao mercado;

- Verificar indicadores de clima e satisfação no local de trabalho;

- Verificar conflitos, greves e reivindicações ocorridas no local de trabalho;

- Verificar reclamações e processos trabalhistas;

- Organizar sistema de informação amplo, democrático e transparente para todos os trabalhadores e funcionários da organização para comunicar os eventos e as atividades. 
A partir de observações predominantemente empíricas, DE FARIA (2009) identificou cinco modelos básicos de gestão, que acabam por determinar os rumos das relações de trabalho:

1. Heterogestão: os empregados não participam do processo decisório e não possuem qualquer controle sobre os elementos constitutivos da gestão do processo de trabalho;

2. Gestão Participativa: os empregados participam de algo que não construíram e portanto não lhes pertence, e tal participação pode ser ainda bastante restrita. Sendo assim, não constituem uma democracia plena;

3. Cogestão: os empregados gerem a organização conjuntamente com os dirigentes. Tal participação dos empregados pode ser restrita nos conselhos superiores, ou então legalmente formais, como no caso da Alemanha;

4. Autogestão: os empregados são seus próprios gestores, e portanto participam plenamente de todo o processo decisório.

5. Gestão Cooperativa: os empregados são sócios entre si nas atividades produtivas;

Um ponto importante de se frisar é que o autor alerta para a questão política de tais classificações, pois em suas pesquisas muitas organizações se autodeclaravam de determinado modelo de gestão por pura conveniência política, isto é, aparentavam usar um modelo de gestão mais prestigioso, mas na prática real se utilizavam de processos tipicamente pertencentes a outro modelo gestão dentre os cinco apresentados.

Para os fins do presente trabalho foram consideradas, a partir da identificação dos modelos, apenas as modalidades ou formas que têm relação direta com a gestão do capital intelectual dos programadores de software. Dessa forma, os modelos "Autogestão" e "Gestão Cooperativa" não são considerados, pois a intenção não é pesquisar modelos nos quais não haja a separação clara entre quem gere a empresa e quem produz diretamente os softwares. 
Sendo assim, auxiliam na determinação de índices para a pesquisa científica os seguintes modelos e sub-modelos de gestão sintetizados por DE FARIA (2009):

1. Heterogestão

1. Absoluta: os empregados são geridos por uma única pessoa (ditador);

2. Oligárquica: os empregados são geridos por um grupo gestor que possui o comando da estrutura da organização;

3. Burocrática Formal: os empregados são geridos por um sistema formal de regras e normas seguindo uma lógica racional.

2. Gestão Participativa

1. Restrita: os empregados têm participação somente dentro de seu grupo de trabalho;

2. Consultiva Pontual: os empregados só são consultados quando isso convém aos dirigentes;

3. Consultiva Representativa: os empregados são consultados através de um sistema formal de representação;

4. Expandida: todos os empregados são consultados através de um sistema formal de representação;

5. Popular ou Coletiva: os empregados são consultados através de associações de defesa coletiva de seus interesses.

3. Cogestão

1. Relativa: os empregados têm alguma representação nos conselhos superiores;

2. Partilhada: os empregados têm uma representação formal e legal nos conselhos superiores. 
Embora os três modelos de gestão e seus respectivos sub-modelos descritos acima não contribuam de forma direta para a determinação de índices para a investigação a que se propõe o respectivo trabalho, é de se destacar sua importância no sentido de sistematizar práticas geralmente tácitas e difusas do mundo empresarial, auxiliando assim na reflexão e no esclarecimento do autor acerca das relações de trabalho, tanto com relação especificamente à produção de software quanto com as relações de trabalho em sua essência universal. 


\subsection{O Programador Segundo Peter Drucker}

Um dos mais influentes e prestigiosos autores de textos e pesquisas sobre a ciência da administração, Peter Druker certamente orientou e formou a opinião de muitos administradores e gerentes de sua geração, além de ter deixado um legado com suas dezenas de publicações, que certamente continuarão a influenciar, em alguma medida, os gestores e empresários de todo o mundo. Nas palavras de EDERSHEIM (2007):

"Peter Drucker? O homem a que se atribui a invenção da disciplina da gestão? O homem que escreveu 39 livros, traduzidos para diversos idiomas? O homem que, sozinho, aconselhou os presidentes da GM (General Motors) e da Ford, que assessorou o presidente do Banco Mundial e o CEO da GE (General Electric), que, segundo se diz, orientou Margaret Thatcher a privatizar todo o setor de mineração da Inglaterra? $O$ homem que exerceu influência formadora em todas as empresas que Jim Collins e Jerry Porras descreveram em 'Feitas para Durar' - organizações lendárias como Hewlett Packard, Johnson \& Johnson, Merck e Motorola?"

Visionário, Peter Drucker sempre antecipou tendências no mundo empresarial, e por muitas vezes dissertou e previu sobre a fundamental importância dos computadores para potencializar a administração nas empresas, como em EDERSHEIM (2007):

“As afirmações de Drucker resistiram ao tempo. Ele relutava em ser descrito como visionário ou vidente. No entanto, pintou visões do futuro espantosamente exatas, graças à sua capacidade de se antecipar às conseqüencias de fatos já ocorridos."

Com relação aos programadores de software, contudo, Peter Druker os considerava apenas um empecilho para a plena utilização das potencialidades computacionais pelos funcionários e gestores das empresas. Além disso, ele previa que, no momento em que a necessidade de programação de softwares desaparecesse (e por conseguinte todos os programadores), os computadores se tornariam, finalmente, uma ferramenta útil de trabalho.

Em DRUKER (1992), ele considera que a programação de softwares é uma "coisa desajeitada, lenta e cara chamada de programação ou 'tradução"'. No seu entender, a maior limitação do computador atual é que: 
"atualmente, o programador, que é um ser humano, tem de ficar entre o computador e o usuário. Ele tem de traduzir a linguagem comum no código do computador. Se não o fizer, o computador não poderá processar os insumos. E então, é claro, não poderá produzir coisa alguma"

A figura do programador de softwares era de um modo geral desprestigiada por Peter Druker, que também de um modo geral não percebia vantagens nas novas oportunidades de empregos que os computadores trouxeram às empresas. Em DRUKER (1992) ele cita: "até agora o principal impacto do computador foi a criação de inúmeras oportunidades de emprego para pessoal de escritório. Isso não representa grande progresso.". Mais especificamente aos programadores de software, Druker, paradoxalmente, os considerava "elementos semi-especializados", ao mesmo tempo em que os considerava totalmente fundamentais para que os computadores pudessem desempenhar suas capacidades:

“( a programação de softwares) é a maior limitação do computador atual. Ela reduz a velocidade até a velocidade do ser humano (...), e também cria a necessidade de empregar essencialmente pessoas semi-especializadas em grande número. No entanto, a capacidade do computador de desempenhar suas funções depende inteiramente da habilidade e conhecimento desses elementos."

Prevendo a total extinção da necessidade da programação de softwares, algo ainda bastante improvável, haja visto o grande número e a grande demanda desse tipo de profissional em todo o mundo, Peter Druker prevê que os computadores somente serão úteis como ferramentas de trabalho nas instituições quando a programação, e por conseguinte os programadores, desaparecerem:

“Quando chegarmos ao ponto de podermos 'queimar' o estágio de programação, (...) transformaremos o computador numa ferramenta de trabalho."

Neste ponto do presente trabalho científico, chegamos a um ponto potencialmente essencial e fundamental na discussão da gestão do capital intelectual dos programadores de software: seria Peter Druker, talvez o maior influenciador e formador de opinião dos tomadores de decisão do mundo empresarial, um agente fortemente desprestigiador do programador de software? 
Há de se fazer ressalvas. Quando Druker escreveu os excertos acima, no ano de 1992, os softwares para microcomputadores, que são os que de fato são utilizados nos escritórios, ainda estavam em um estágio inicial de desenvolvimento, que somado aos hardwares (processadores e memórias) de menor capacidade, criavam softwares de difícil manipulação por leigos em programação. Também é fato que àquela época a Internet, como largamente é utilizada atualmente, simplesmente não existia. Sendo assim, todas as condições para se utilizar eficientemente um microcomputador no ambiente de trabalho eram mais difíceis. Atualmente, há uma grande quantidade de softwares largamente utilizados que existem desde aquela época, e que hoje já estão em versões acima da décima. Como em cada nova versão várias melhorias e correções são acrescentadas, sua utilização por leigos em programação torna-se extremamente fácil, dispensando totalmente a necessidade de programadores e de "pessoal de escritório", como Drucker chamava o pessoal de suporte técnico nas empresas.

De qualquer forma, é inegável a grande influência e até mesmo um legado do prestigioso autor no sentido de se criar um paradigma mundial de gestão do programador de software, no qual o mesmo tem um papel paradoxalmente fundamental e marginal nas organizações. 


\subsection{O Mito do Fim da Programação}

Um erro recorrente de gestores e tomadores de decisão não-programadores é o de que a tarefa de programar softwares pode um dia simplesmente não ser mais necessária.

Uma possível explicação para essa tendência pode estar no processo de venda, pois, ao tentar convencer o tomador de decisões a comprar o software oferecido, muitas vezes o vendedor dá a entender que, uma vez desenvolvido e "instalado", o software não necessitará mais de programadores. RUHL (1989) cita:

"Muitas vezes os vendedores extrapolam ao garantir para o hesitante executivo que ele não ficará dependente dos programadores. Murmurando termos técnicos impactantes, o vendedor vislumbra um futuro maravilhoso, no qual os computadores vão se auto-programar."

É falso pensar que a atividade de programar softwares um dia terminará, pois um software controla processos que estão em constante mutação, tal qual a economia moderna. Novas demandas, novas tecnologias, novos bens e serviços surgem constantemente nas economias globalizadas, sendo assim é improvável esperar que um software seja uma solução satisfatória de controle no longo prazo. Logo, um software é algo dinâmico e que precisa de atualizações constantes, pois assim são os processos de produção de bens e serviços aos quais espera-se que ele controle. A esse propósito RUHL (1989) diz:

“A má notícia para a alta administração é que um sistema nunca está inteiramente acabado. Quando os seus negócios mudam, seus sistemas computacionais precisam mudar também. Não há uma solução fácil para isso. E mudar um sistema computacional corretamente é um empreendimento caro, que requer pessoal qualificado, especialmente programadores - exatamente os mesmos programadores que o executivo esperava poder eliminar assim que o sistema estivesse instalado." 
Dessa forma, o presente trabalho pressupõe como falsa e mítica a expectativa de que a necessidade de se programar softwares com o auxílio direto ou indireto de pessoas termine. Conclui-se assim que a função de programador de softwares continuará altamente relevante e necessária na economia mundial, e por tempo indeterminado. 


\subsection{O Processo Errático Clássico no Desenvolvimento de Softwares}

Parece haver nas empresas em geral um processo repetitivo e errático na aquisição ou no desenvolvimento interno de softwares sob medida (não-empacotados). O processo é em essência muito similar nas empresas em geral, e exceções são raras ou mesmo inexistentes.

A essência do problema está no fato de que os softwares são primeiramente vendidos por vendedores persuasivos, em seguida são planejados pela alta diretoria, e só então são de fato construídos pelos programadores. Geralmente os programadores não participam nem do processo de venda e nem do planejamento do sistema, além de que os próprios vendedores não possuem nenhum conhecimento ou prática das técnicas e competências necessárias para o planejamento e construção do que acabam de vender, isto é, um software.

Após a venda, a alta diretoria decide, geralmente sem a participação da equipe de programadores, sobre todas as funcionalidades básicas que o novo sistema deverá possuir. Se, após ficar pronto, o software não corresponder a todas as necessidades inicialmente esperadas pelo comprador (algo que ocorre com freqüência), o que se tem é a promessa de que a versão seguinte solucionará todas as pendências. Finalmente, como o projeto inicial e básico do software foi errático no sentido de não se incluir na venda e no planejamento iniciais uma das figuras fundamentais, o programador, produz-se então um impasse que ameaça a eficiência e até mesmo a sobrevivência de uma empresa: uma dependência indesejada, porém necessária, da equipe de desenvolvimento de softwares, composta majoritariamente por programadores. A expectativa de um novo software que melhoraria os processos trazendo grandes reduções de custo, conforme prometido no momento da venda, se torna um caro e desgastante conflito entre comprador-vendedor, ficando o programador como potencial bode expiatório, devido a sua tradicional pouca força política dentro das organizações. 


\subsection{As "Balas de Prata” da Produção de Software}

O termo "bala de prata" foi inicialmente usado no mundo do desenvolvimento de softwares por BROOKS (1987) apud YOURDON (1995). A metáfora que explica o termo se baseia na lenda popular de que o lobisomem, homem comum que se transforma em um lobo assassino, só pode ser morto com um tiro de uma bala de prata. Segundo o autor, o lobisomem representa a produção de um software para um gestor não-técnico, isto é, um gestor encarregado da coordenação e da conclusão efetiva de um software. Já a "bala de prata" seria alguma metodologia ou técnica mirabolante e absoluta, que resolveria de uma só vez todos os problemas de uma produção problemática de um software.

"O projeto de software familiar, pelo menos como é visto pelo gerente não-técnico, tem alguma coisa desse personagem (lobisomem): normalmente inocente e leal, mas é capaz de tornar-se um monstro de prazos não cumpridos, orçamentos estourados $e$ produtos defeituosos. Desse modo, ouvimos clamores desesperados por uma bala de prata (...) mas, (...) não há um único desenvolvimento, em tecnologia ou em técnicas gerenciais, que por si prometa pelo menos uma melhoria de produtividade, confiabilidade e simplicidade de uma ordem de magnitude". 


\section{ELABORAÇÃO DA REVISÃO TEÓRICA INICIAL}

\subsection{A Noção de Peopleware}

O termo peopleware, que ganhou força com a publicação de DE MARCO \& LISTER (1999), é um idéia que complementa os termos software e hardware, ambos largamente usados nos meios acadêmico e empresarial. No mundo da tecnologia da informação e dos computadores em geral, hardware se refere a tudo que é físico, como placas, memórias e processadores, e software se refere a tudo que é essencialmente intangível, como os programas, sistemas e metodologias de programação. Já o termo peopleware se refere, no mundo de TI, ao fator humano no processo de desenvolvimento de softwares.

Apesar de não ser um conceito propriamente dito, o peopleware é uma forma de rotular a administração das pessoas no ambiente de trabalho das empresas que produzem software. Conforme YOURDON (1997):

"Trata-se de uma idéia antiga: bons profissionais produzem software bom. Apesar de as ferramentas e metodologias serem importantes, e apesar de serem importantes os administradores racionais e um ambiente decente de trabalho, o ponto de partida para a empresa de software altamente produtivo são os bons profissionais"

Já HEHN (1999) define peopleware como "a interação das pessoas e seus modelos mentais, valores e crenças coletivas com os diversos elementos estruturais ligados a ela". $\mathrm{O}$ autor define que os elementos estruturais são:

- Políticas e sistemas de recursos humanos (compostos por: recrutamento e seleção, avaliação de desempenho, remuneração, premiação e carreira),

- As responsabilidades e os papéis exercidos,

○ Lógica da estruturação de objetivos e 
○ Estrutura organizacional.

Em sua explicação, o autor diz que os modelos mentais, valores e crenças coletivas são o núcleo de formação do peopleware, que é então fundamentalmente complementado pelo que chama de elementos estruturais, classificados como uma "casca de proteção".

Além de apenas rotular a administração de pessoas nas empresas produtoras de software, o termo peopleware representa um esforço no sentido de promover a importância de se ater à gestão do capital intelectual dos profissionais envolvidos com a tecnologia da informação, da qual os programadores têm papel fundamental.

Contrapondo-se a esse esforço, há uma mentalidade que defende que as pessoas têm muito pouca importância no processo de produção de softwares. Conforme HOARE (1970) apud YOURDON (1995):

"Basicamente todos os problemas são técnicos. Se você souber o que quer fazer e tiver a necessária formação técnica, não há razão para transformar isso num grande problema gerencial. Obviamente, certa quantidade de controle de recursos e trabalho do pessoal terá de entrar em ação, mas isso é tudo"

O interessante na citação acima é que tais orientações, nas quais claramente o fator humano é considerado algo de menor importância, estão descritas na ata de uma conferência da OTAN (Organização do Tratado do Atlântico Norte) sobre engenharia de software, organização de grande influência e que é composta por EUA, Canadá e poderosos países europeus. Dessa forma, é possível afirmar que tal diretriz em relação à administração do capital intelectual é potencialmente paradigmática, e assim representa uma forte influência no sentido de que os gestores se preocupem mais com as técnicas de produção de softwares do que com as pessoas envolvidas no processo.

No intuito de orientar acerca de boas práticas de peopleware, YOURDON (1995) define seis regras básicas:

1. Contratar o melhor pessoal.

2. Engajar-se no contínuo treinamento e educação da equipe existente. 
3. Motivar o pessoal para a obtenção de níveis mais elevados de desempenho.

4. Desenvolver idéias de gerenciamento do desempenho para alinhar as metas pessoais e as metas corporativas.

5. Oferecer um ambiente de trabalho com ênfase em instalações de escritório adequadas.

6. Criar e manter equipes eficazes, que possam trabalhar para criar produtos de software de alta qualidade.

Sendo assim, fica clara a posição do autor no sentido de valorização dos aspectos relativos ao peopleware nas empresas produtoras de software. Apesar de não apresentar exemplos concretos que comprovem, ele afirma, baseado em sua experiência como programador e como pesquisador, que "a atenção às questões de peopleware pode literalmente causar melhorias de produtividade dez vezes maiores, ao passo que os investimentos (...) em metodologias e outras tecnologias raramente causam uma melhoria maior do que 30 a $40 \%$ ".

Já HEHN (1999) alerta para as conseqüências positivas de se enquadrar nas boas práticas de peopleware, descrevendo para tanto as vantagens potenciais que tal noção traz às organizações. São elas:

- Modelo de organização integrado e orientado para processos.

- Segundo o autor, o peopleware bem administrado é fundamental para se adequar às necessidades mais modernas das organizações, que necessitam continuamente cortar custos, têm ciclos de negócios cada vez mais reduzidos e demandam grande flexibilidade.

- Uso de todo o potencial de um sistema integrado.

○ Para o autor, ter na organização um sistema de informática que integre todos os processos e divisões das organizações de nada adianta se as pessoas que o operam não tiveram seus valores e crenças adaptados à nova realidade integrada. 
- Minimização de resistências à mudança e sabotagens

- Estando a organização enquadrada nas boas práticas de peopleware, a tendência, principalmente no processo de implementação de um novo sistema informático integrado, é de minimização de custos, pois a resistência a mudanças e até mesmo sabotagens são comuns quando as pessoas não estão devidamente alinhadas à estratégia da alta direção. 


\subsection{O Conceito de Capital Intelectual}

O conceito de capital intelectual é já bastante conhecido há muitas décadas, e portanto não se constitui em um conceito novo, conforme ANTUNES \& MARTINS (2000), quando afirmam que o capital intelectual é parte integrante do conceito contábil de Goodwill, conceito este já conhecido e estudado há mais de um século. Em uma definição sucinta, os autores definem o capital intelectual como "um conjunto de benefícios intangíveis que agregam valor às empresas”. O mesmo é dito em BROOKING (1997): “o capital intelectual não é novo. Ele está aí desde quando o primeiro vendedor estabeleceu uma boa relação com um cliente. Então ele passou a ser chamado de goodwill".

O intangível está de fato na essência do conceito de capital intelectual. SVEIBY (1997) não usa o termo propriamente dito, porém considera o que chama de competência individual ou de competência do empregado uma das três partes que compõem os bens intangíveis das empresas, também chamada de prêmio do valor da ação, isto é, o valor real da ação de uma empresa no mercado financeiro subtraído de seu valor nos livros contábeis. De forma sistemática, o autor divide os bens intangíveis em:

- Estrutura externa: composta pelas marcas, carteira de clientes e relações com fornecedores;

- Estrutura interna: a organização em geral, o que inclui a gestão em si, a estrutura legal, as normas, as atitudes, a P\&D e os softwares.

- Competência individual (ou competência do empregado): a capacidade do empregado em agir em uma ampla variedade de situações, utilizando-se de sua formação e experiência.

Para EDVINSSON \& MALONE (1997), o termo capital intelectual possui diversos sinônimos. São eles: "capital originário do conhecimento", "ativos não-financeiros", "ativos imateriais", "ativos ocultos", "ativos invisíveis" e "meios para se alcançar metas". Além 
desses 6 sinônimos, é citada uma fórmula que diz que o capital intelectual é igual ao valor de mercado menos o valor contábil de uma empresa:

$$
\mathrm{CI}=\mathrm{VM}-\mathrm{VC}
$$

É descrito um processo da empresa sueca Skandia, que criou uma metodologia para se gerar relatórios de capital intelectual, complementares aos relatórios contábeis-financeiros tradicionais. Nesse processo, chegou-se a três fundamentos essenciais, que na verdade são pressupostos:

- O capital intelectual é uma informação suplementar e não-subordinada às informações financeiras.

- O capital intelectual é um capital não-financeiro, e representa, assim como exposto acima, a diferença entre o valor de mercado e o valor contábil das empresas.

- O capital intelectual é um passivo, e não um ativo, e portanto se constitui em um empréstimo junto aos clientes e funcionários. Nesse ponto chega-se a uma constatação notável, pois há uma clara distinção entre capital intelectual e goodwill. A explicação dada é a de que o goodwill é tradicionalmente considerado pela contabilidade como um ativo desprezível, que deve ser amortizado o mais rápido possível, e que portanto reduz o valor do balanço patrimonial. Por outro lado, a idéia de capital intelectual é exatamente o contrário, isto é, ele é uma riqueza da empresa, que aumenta, e não diminui, seu patrimônio.

Para os autores, o capital intelectual possui três formas básicas:

- Capital Humano: inclui não somente as capacidades, conhecimentos, habilidades e experiências, como também todos os processos envolvidos na dinâmica dessas qualidades individuais dentro da empresa, tais como a criatividade e a inovação organizacionais. 
São citados como exemplos a questão da existência ou não de processos contínuos de treinamento e aprendizagem dos funcionários e gestores, além da transmissão dos conhecimentos dos veteranos aos novatos dentro do processo produtivo em geral.

Dentro da idéia de capital humano também é interessante a indagação se existe ou não fenômenos potencialmente negativos para a instituição, tal como a tendência de monopolização do conhecimento empresarial adquirido, como forma de concentrar poder de influência nas mãos de quem detém o conhecimento e não o compartilha com os colegas de trabalho. Neste exemplo dado, pode-se considerá-lo como um custo de influência.

- Capital Estrutural: é composto por uma grande diversidade de componentes, que resultam em toda a infraestrutura que apóia o capital humano. Para explicar melhor os componentes do capital estrutural, os autores os dividiram em três grupos:

○ Capital Organizacional: são os investimentos da empresa em um sistema abrangente, que possibilita o fluxo de conhecimento tanto internamente na organização quanto externamente, através de toda a cadeia produtiva em que estiver inserida. "Trata-se da competência sistematizada, organizada e codificada da organização e também dos sistemas que alavancam aquela competência”.

- Capital de Inovação: é a capacidade da empresa em inovar, gerando direitos comerciais e ativos de propriedade intelectual através de novos produtos e serviços.

○ Capital de Processos: composto pelos processos, técnicas e programas de aperfeiçoamento de funcionários, que aumentam a eficiência no processo produtivo.

- Capital de Clientes: é basicamente o relacionamento da empresa com seus clientes. $\mathrm{O}$ autor, sem se alongar na reflexão, considera o capital de clientes um sinônimo do conceito contábil de goodwill. 
É feita uma ressalva no sentido de explicar que a idéia de capital de clientes é um desmembramento da idéia inicial de capital organizacional, explicada pelas diferenças básicas entre o relacionamento que uma empresa tem com seus funcionários e fornecedores e o relacionamento com seus clientes.

Entretanto, o autor revela sua desconfiança sobre a possibilidade de o termo capital de clientes ser apenas uma forma oportunista de promoção da empresa junto aos acionistas e investidores em geral.

Em BROOKING (1997) o conceito de capital intelectual possui surpreendentes 40 definições diferentes. Entretanto, ao se analisar com atenção cada um deles, chega-se à conclusão de que na verdade 39 deles não são exatamente definições, mas sim pressupostos e conselhos para se gerir de forma correta o capital intelectual nas instituições. O único que é propriamente uma definição do conceito de capital intelectual é exatamente o primeiro, que é uma fórmula essencialmente idêntica à definição de EDVINSSON \& MALONE (1997):

$$
\text { Empresa }=\text { Ativos Tangíveis }+ \text { Capital Intelectual }
$$

Com uma simples operação algébrica, e considerando-se que "empresa" representa o seu valor de mercado, tem-se que o capital intelectual é igual ao valor de mercado (empresa), subtraído de seus ativos tangíveis.

A autora divide o capital intelectual em 4 componentes básicos:

- Ativos de Mercado: são os bens intangíveis relacionados diretamente com o mercado, tais como as marcas, a lealdade dos clientes, os canais de distribuição e as franquias, entre outros.

- Ativos de Propriedade Intelectual: são os vários tipos de patentes, além de know-how e segredos comerciais que uma organização possui. 
- Ativos Humanos: são compostos por: conhecimento coletivo, capacidade e criatividade em resolver problemas, liderança e habilidade de empreender e de gerir.

- Ativos de Infraestrutura: são as tecnologias, metodologias e processos que permitem o funcionamento da organização. É importante notar que não se trata de ativos tangíveis tais como computadores e máquinas, mas sim do uso que se faz delas.

STEWART (1998) procura definir o conceito de capital intelectual preocupando-se em escolher as palavras certas, no sentido de que a definição seja clara e direta para os funcionários e gestores. Ele faz uma reflexão crítica a respeito de outras definições anteriormente dadas, para em seguida definir capital intelectual como "conhecimento útil em nova embalagem". Em outras palavras, o autor quer dizer que o capital intelectual surge no momento em que a inteligência é organizada e sistematizada de forma coerente, permitindo que a mesma seja "descrita, compartilhada e explorada". Exemplos como um banco de dados ou a descrição de um processo são dados para ilustrar a ideia. São apresentadas também outras definições para o conceito de capital intelectual: "soma do conhecimento de todos em uma empresa, o que lhe proporciona vantagem competitiva", e também “é a matéria intelectual - conhecimento, informação, propriedade intelectual, experiência - que pode ser utilizada para gerar riqueza”. Já em STEWART (2001), o mesmo autor define o capital intelectual como um "conhecimento que transforma matérias-primas, tornando-as mais valiosas".

Para TEECE (2000), os ativos intangíveis são compostos basicamente por conhecimento, competência e propriedade intelectual, além das marcas, reputações e relações com os consumidores, entre outros não citados. Ele faz uma comparação para distinguir ativos intangíveis de ativos tangíveis, sendo os ativos intangíveis (também chamados pelo autor de ativos de conhecimento) a idéia mais próxima, ou possivelmente um sinônimo, para o conceito de capital intelectual. São usados quatro parâmetros básicos para a comparação: 
- Conceito de Bem Público (publicness): com relação ao conceito econômico de bem público, o uso de um ativo intangível não reduz a oferta do ativo para as demais pessoas, ao contrário de um ativo físico (tangível).

- Depreciação: segundo o autor, os ativos intangíveis não se desgastam, porém normalmente se depreciam rapidamente por causa do processo de criação de conhecimento. Já os ativos tangíveis se desgastam e podem se depreciar lenta ou rapidamente.

- Custos de Transferência: nos ativos intangíveis é difícil de serem calibrados devido à natureza tácita do conhecimento, apesar de que as barreiras geográficas para o transporte desse tipo de ativo serem muitas vezes inexistentes. Já os custos de transferência dos ativos tangíveis são mais fáceis de serem calibrados.

- Direitos de Propriedade: para os ativos intangíveis os direitos de propriedade são difusos e limitados (como por exemplo as patentes que expiram e não podem ser renovadas), ao contrário dos ativos tangíveis, aos quais os direitos de propriedade são relativamente mais fáceis de se definir e contém menos brechas legais. Além disso, há a afirmação de que, para os ativos intangíveis, a execução judicial de um direito de propriedade é relativamente mais difícil que no caso de ativos físicos.

De um modo geral, entende-se que o conceito de capital intelectual é algo já há muito tempo percebido e estudado, porém há de se admitir que existe algo de novo no assunto, pois de fato o capital intelectual é um parte menor do conceito contábil de goodwill, parte essa que é vista de forma mais minuciosa e precisa. Conforme SANTIAGO JÚNIOR \& SANTIAGO (2007): “O capital intelectual sempre existiu. O que é novo é o reconhecimento, de forma explícita, com relação à sua importância para o negócio."

Já BROOKING (1997) explica, ao também afirmar que o capital intelectual existe há muito tempo, que nas últimas décadas houve uma "explosão" de áreas técnicas chave, dentre elas as tecnologias da informação e da comunicação. Tais 
novas tecnologias criaram vantagens intangíveis que antes não existiam, e das quais as empresas se tornaram profundamente dependentes. Assim, o controle de tais vantagens intangíveis traz vantagem competitiva. 


\subsection{A Gestão do Capital Intelectual}

A empresa sueca de serviços financeiros Skandia foi a pioneira, a partir da década de 1990, a estabelecer uma governança que prioriza formalmente a gestão do capital intelectual. Liderada por Leif Edvinsson, uma equipe concentrou esforços no sentido de definir o que é capital intelectual e como medi-lo dentro da empresa. Após alguns anos de trabalhos e pesquisas, chegou-se a um instrumento de análise e mensuração não só do capital intelectual, mas como também de todo o valor global da empresa, nomeado Navegador Skandia,

O Navegador Skandia, conforme descrito em EDVINSSON \& MALONE (1997), é constantemente modificado e aperfeiçoado, porém sua estrutura básica se mantém. Essa estrutura é composta por cinco "áreas de foco”. São elas:

- Foco Financeiro: é composto basicamente pelo balanço patrimonial e diversos indicadores financeiros. $\mathrm{Na}$ verdade o foco financeiro, de acordo com a descrição do Navegador Skandia, não faz parte do que é considerado capital intelectual, porém, como dito anteriormente, o navegador serve também como instrumento de medição do valor global da empresa. No que se refere ao capital intelectual dos programadores e aos objetivos do presente trabalho, o foco financeiro não tem aplicação prática e por isso seus indicadores não serão levados em consideração.

- Foco no Cliente: assim como no foco financeiro, chega-se à conclusão de que, apesar de ser um foco que compões o que seus autores consideram como capital intelectual, o chamado foco no cliente não tem aplicação prática direta na investigação científica objetivada pelo presente trabalho. Basicamente o foco no cliente tem seus indicadores divididos entre cinco categorias: tipo de cliente, duração do cliente, papel do cliente, suporte ao cliente e sucesso do cliente.

- Foco no Processo: o foco no processo é fortemente baseado em infraestrutura tecnológica, mais especificamente em tecnologia da informação (TI). São definidas quatro regras básicas para se definir os índices que compõem essa parte do capital intelectual:

- A tecnologia do processo só deve fazer parte do cálculo se a mesma contribuir para o valor da empresa. 
- Os índices devem medir a qualidade do suporte à tecnologia oferecido pelo fornecedor.

○ Os índices devem medir não só a produtividade do processo em si, mas também a produtividade da empresa como um todo.

- Os índices gerados devem ser passíveis de serem comparados a metas prédeterminadas.

Ao se analisar tanto as regras para definição dos índices quanto a lista de 31 índices sugeridas no livro, chega-se também à conclusão de que o foco no processo como descrito não tem aplicação prática na avaliação da gestão do capital intelectual dos programadores, objetivo geral do presente trabalho.

- Foco em Renovação e Desenvolvimento: esse é o extremo oposto do foco financeiro, que se relaciona com o passado. $\mathrm{O}$ foco em renovação e desenvolvimento se concentra portanto no futuro da empresa. Ao contrário dos três primeiros focos analisados, esse de fato contém inegavelmente aplicação prática na investigação da gestão do capital intelectual dos programadores.

O foco em renovação e desenvolvimento está estruturado em 6 dimensões, sejam elas Clientes, Atração no Mercado, Produtos e Serviços, Parceiros Estratégicos, Infra-Estrutura e Empregados. Cada uma das 6 é explicada apenas usando-se de várias perguntas. A parte diretamente aplicável ao objetivo geral do presente trabalho é a dimensão "Empregados". Algumas das perguntas feitas para explicá-lo são:

○ Qual é o nível médio de instrução dos colaboradores da empresa?

○ Quantos possuem MBA?

○ Qual é a quantidade média de treinamento, em horas, de cada empregado por mês?

São ao todo apresentados 79 índices para se medir o foco em renovação e desenvolvimento, sendo 18 em uso na Skandia e os 61 restantes sugestões para uso em 
empresas das mais variadas naturezas. Para o presente trabalho de pesquisa, foram selecionados e adaptados preliminarmente os seguintes índices:

○ Índice de poder de decisão (empowerment) dos programadores.

○ Índice de satisfação dos programadores.

- Índice de treinamento dos programadores.

○ Grau de instrução dos programadores.

- Foco Humano: segundo os autores, "constitui o coração, a inteligência e a alma da organização". Além disso eles dizem que "somente o fator humano interpenetra os outros fatores, atuando como um agente ativo sobre todos os demais". Antes de entrar especificamente nos indicadores para o foco humano, são expostas regras fundamentais para defini-los corretamente: devem ser bem fundamentados, bem estruturados e teleológicos.

De fato, os índices sugeridos do foco humano são os mais aplicáveis no que se diz respeito ao presente trabalho, já que os programadores são afinal seres humanos desempenhando funções específicas e vitais em uma organização. Segue uma seleção de índices que são de grande aplicabilidade na investigação da gestão do capital intelectual dos programadores:

○ Índice Motivacional.

○ Índice de Rotatividade.

○ Índice Hierárquico.

A mesma estrutura básica do Navegador Skandia é usada na análise da gestão do capital intelectual em STEWART (1998). Sendo assim são usados os conceitos de capital humano, capital estrutural e capital de clientes. Apesar de o autor adicionar pouca coisa em termos conceituais ao que foi dito em EDVINSSON \& MALONE (1997), ele faz um interessante resumo de dez princípios de gestão do capital intelectual. Dentre esses princípios surgiram embasamentos para a proposição de 
índices adicionais, de acordo com os objetivos de pesquisa do presente trabalho. Em uma passagem, o autor diz:

"O capital humano e o capital do cliente crescem quando os indivíduos se sentem responsáveis por suas partes na empresa, interagem diretamente com os clientes e sabem quais conhecimentos e habilidades os clientes esperam e valorizam. Um funcionário que não conhece ou não possui essas habilidades diminui o valor tanto do capital humano quanto do capital do cliente".

Da passagem acima pode-se gerar um índice já selecionado anteriormente, o índice de poder de decisão (empowerment), e mais o seguinte:

○ Índice de Contato Direto com Clientes.

De outra passagem, que diz que "uma empresa precisa estimular o trabalho em equipe, comunidades de prática e outras formas sociais de aprendizado", pode-se gerar um índice adicional:

○ Índice de Coleguismo

Como já descrito, BROOKING (1997) analisa a gestão do capital intelectual a partir de quatro componentes básicos. O primeiro deles é o chamado Ativos de Mercado. Sua análise é centrada na importância das marcas e da lealdade dos clientes para se estabelecer estratégias de sucesso no mercado, o que, embora seja de interesse com relação à gestão do capital intelectual em geral, não se aplica aos objetivos do presente trabalho, que é analisar especificamente os programadores de software.

Já o componente chamado Ativos de Propriedade Intelectual também tem baixa aplicação no presente trabalho, pois centra-se a discussão na questão da gestão de patentes e similares. Embora também faça parte desse componente do capital intelectual a questão do know-how, o mesmo somente é discutido pela autora no componente Ativos Humanos. 
No componente Ativos Humanos, a autora ressalta a importância da constante medição e acompanhamento de seus funcionários, no sentido de se maximizar o potencial de cada um dentro da organização, pois isso traz resultados financeiros duradouros. São discutidos os elementos Educação, Vocação, Conhecimentos, Avaliação Ocupacional \& Psicometria e Competências. Desses cinco elementos, podemos sugerir mais dois novos índices, que serão explorados mais adiante no presente trabalho:

○ Índice Vocacional

○ Índice Ocupacional

Os chamados Ativos de Infraestrutura são, segundo a autora, o esqueleto e a liga da organização. Eles possuem os seguintes 6 elementos: Filosofia de Gestão, Cultura Corporativa, Processos de Gestão, Sistemas de Tecnologia da Informação, Sistemas de Rede e Relações Financeiras. No que concerne aos objetivos do presente estudo, pode-se gerar um índice já discutido e selecionado anteriormente, o índice de poder de decisão (empowerment), e mais um outro índice, que verifica a existência de um sistema de conhecimento organizacional que possibilite que o conhecimento fique retido na empresa, podendo ser constantemente consultado e enriquecido:

○ Índice do sistema de conhecimento organizacional.

Outro aspecto interessante para o propósito do presente trabalho é que SVEIBY (1997), em sua discussão sobre a gestão do capital intelectual, define que há, no que ele chama de empresa do conhecimento (knowledge company), quatro principais atores (players): os profissionais, dentre os quais estão os experts, que são "geradores genuínos de receita", os gestores, o pessoal de apoio e os líderes.

Fica evidente que dentre os quatro atores mencionados, aquele mais próximo dos programadores são os profissionais. Não poderia ser gestores, pois mesmo que um programador se torne um, certamente ele deixará ao menos parcialmente de programar e se envolverá com tarefas distintas. Como já dito anteriormente, o programador é o agente central na atividade de produzir 
softwares, portanto também não se pode admitir encaixá-lo como pessoal de apoio. Já o líder, conforme explicado pelo autor, tem o papel de motivar os gestores, no sentido de ajudá-los a lidar com os conflitos destes com os experts.

Concluindo-se então que os programadores estão classificados de acordo com a idéia de profissionais e que o autor conclui que "os profissionais nas organizações do conhecimento são geradores de receitas; a atenção deve estar focada nas receitas que geram, e não nos custos que causam", pode-se assim sugerir o seguinte índice para a pesquisa acerca da gestão do capital intelectual dos programadores, que procura investigar se um programador é considerado um custo ou um investimento por parte do empregador:

○ Índice do Papel Contábil.

Continuando na conclusão do autor acerca dos profissionais, afirma-se que a empresa que faz uma gestão adequada do capital intelectual deve preocupar-se em proporcionar condições para que os profissionais sejam criativos e assim criar valor para os clientes, ao mesmo tempo em que deve criar um sistema de documentação no qual o conhecimento gerado fique retido na empresa, de forma que a mesma não fique dependente dos profissionais e experts. Sendo assim, podese definir um índice que investiga a existência ou não de um sistema de retenção e consulta ao conhecimento organizacional, índice esse já citado anteriormente.

Em TEECE (2000) o indivíduo, o ser humano propriamente dito, não é diretamente discutido no sentido de como se gerir o capital intelectual. De um modo geral, o autor tem como foco principal a discussão estratégica a respeito da administração das inovações, e de como protegê-las contra imitadores. Usando-se de numerosas citações de casos ocorridos em grandes empresas, o autor propõe e discute modelos gerenciais no sentido de proteger as invenções criadas a partir do intelecto e do trabalho de seus funcionários. Levando-se em consideração o foco dado na obra, ao invés de "Gestão do Capital Inicial", talvez o nome mais adequado para o livro fosse "Gestão da Inovação". Sendo assim, devido ao foco fortemente distinto dos demais autores consultados, não se encontrou um caminho para a definição de novos índices a partir da obra consultada. 
Como forma de sistematizar as principais idéias a respeito do conceito de capital intelectual, segue um resumo com as palavras-chave básicas dos autores estudados a respeito do conceito. Na última coluna, à direita, foram selecionados aspectos contidos nas definições do conceito. A seleção se baseia no que se refere diretamente aos programadores de software, no sentido de se identificar fatores que possam ser diretamente investigados pelo presente trabalho: 
Tabela 3 - O conceito de capital intelectual e seus pressupostos

\begin{tabular}{|c|c|c|c|}
\hline Autores & Componentes do C.I. & $\begin{array}{c}\text { Aspectos do C.I. inerentes aos } \\
\text { programadores }\end{array}$ & $\begin{array}{c}\text { Pressupostos do C.I. inerentes ao programador } \\
\text { excelente }\end{array}$ \\
\hline SVEIBY & $\begin{array}{l}\text { - Estrutura Externa } \\
\text { - Estrutura Interna } \\
\text { - Competência } \\
\text { Individual }\end{array}$ & $\begin{array}{l}\text { Capacidade do empregado } \\
\text { em agir em uma ampla } \\
\text { variedade de situações, } \\
\text { utilizando-se de sua } \\
\text { formação e experiência }\end{array}$ & $\begin{array}{l}\text { - Ter boa formação } \\
\text { - Ter boa experiência } \\
\text { - Ter seu C.I. considerado como um passivo } \\
\text { - Ter acesso a um bom sistema de } \\
\text { conhecimento organizacional }\end{array}$ \\
\hline $\begin{array}{l}\text { EDVINSSON } \\
\& \text { MALONE }\end{array}$ & $\begin{array}{l}\text { - Capital Humano } \\
\text { - Capital Estrutural } \\
\text { - Capital de Clientes }\end{array}$ & $\begin{array}{l}\text { Capacidades, } \\
\text { conhecimentos, } \\
\text { habilidades e experiências. } \\
\text { - Processos, técnicas e } \\
\text { programas de } \\
\text { aperfeiçoamento de } \\
\text { funcionários, que } \\
\text { aumentam a eficiência no } \\
\text { processo produtivo. }\end{array}$ & $\begin{array}{l}\text { - Ter boa formação } \\
\text { - Ter boa experiência } \\
\text { - Ter bom treinamento } \\
\text { - Ter seu C.I. considerado como um passivo } \\
\text { - Ter poder de decisão (empowerment) } \\
\text { - Ter satisfação no trabalho } \\
\text { - Ter motivação para o trabalho } \\
\text { - Ter baixa rotatividade }\end{array}$ \\
\hline BROOKING & $\begin{array}{l}\text { - Ativos de Mercado } \\
\text { - Ativos Humanos } \\
\text { - Ativos de } \\
\text { Propriedade } \\
\text { Intelectual } \\
\text { - Ativos de } \\
\text { Infraestrutura }\end{array}$ & $\begin{array}{l}\text { - Educação, vocação, } \\
\text { conhecimento e } \\
\text { competência }\end{array}$ & $\begin{array}{l}\text { - Ter vocação } \\
\text { - Ter boa formação } \\
\text { - Ter boa experiência } \\
\text { - Ter acesso a um bom sistema de avaliação } \\
\text { ocupacional } \\
\text { - Ter acesso a um bom sistema de } \\
\text { conhecimento organizacional } \\
\text { - Ter poder de decisão (empowerment) }\end{array}$ \\
\hline STEWART & $\begin{array}{l}\text { - Conhecimento } \\
\text { - Informação }\end{array}$ & $\begin{array}{l}\text { - Inteligência organizada e } \\
\text { sistematizada de forma } \\
\text { coerente, permitindo que a } \\
\text { mesma seja descrita, }\end{array}$ & $\begin{array}{l}\text { - Ter acesso a um bom sistema de } \\
\text { conhecimento organizacional } \\
\text { - Ter poder de decisão (empowerment) }\end{array}$ \\
\hline
\end{tabular}




\begin{tabular}{|c|c|c|c|}
\hline & $\begin{array}{l}\text { Propriedade } \\
\text { intelectual } \\
\text { - Experiência }\end{array}$ & $\begin{array}{l}\text { compartilhada e } \\
\text { explorada. }\end{array}$ & $\begin{array}{l}\text { - Ter contato direto com o cliente } \\
\text { - Ter boa interação com os colegas de } \\
\text { trabalho }\end{array}$ \\
\hline TEECE & $\begin{array}{l}\text { - Conhecimento } \\
\text { - Competência } \\
\text { - } \begin{array}{l}\text { Propriedade } \\
\text { Intelectual }\end{array} \\
\text { - Reputação } \\
\text { - Relação com o } \\
\text { Consumidor }\end{array}$ & $\begin{array}{l}\text { - (Teece foi pouco } \\
\text { específico) }\end{array}$ & - (Teece foi pouco específico) \\
\hline
\end{tabular}

Fonte: o autor

Sendo assim, a partir da revisão teórica inicial feita, extraíram-se 13 pressupostos para a gestão excelente do capital intelectual dos programadores de software, que por conseguinte resultarão na geração de seus índices correspondentes. 


\section{METODOLOGIA DA PESQUISA}

\subsection{Pressupostos}

\subsection{O Desprestígio do Programador}

Minha experiência profissional prática como programador de software em diversas instituições e as práticas repetidamente utilizadas pelo mercado em geral levam a considerar como pressuposto que o programador é, em sua imensa maioria, desprestigiado como trabalhador de alto nível técnico e intelectual. Isso significa que no presente trabalho é tomado como pressuposto que, em sua grande maioria, os programadores não são ouvidos adequadamente, e não participam de decisões nem de nível tático e tampouco de nível estratégico nas empresas em que desenvolvem softwares. RUHL (1989) cita:

"Em um típico organograma hierárquico (...) os programadores ficam sempre na base. Os seus nomes sequer aparecem no organograma dentro de caixas; isso é verdade, pouco importando seu nível técnico ou os seus salários"

Sendo assim, é considerado como pressuposto básico do presente trabalho que os programadores são de modo geral desprestigiados no meio corporativo, no sentido de não participarem de decisões de níveis estratégico ou tático nas empresas, limitando-se na maior parte das vezes a tomar decisões de nível meramente operacional.

\subsection{O Conceito de Capital Intelectual}

O exercício de se estudar tanto os autores dos conceitos teóricos sobre o capital intelectual, quanto o setor produtor de software de Brasil e Canadá, levou à síntese dos 13 pressupostos teóricos básicos, que por conseguinte geraram os 13 índices do presente trabalho científico. Entende-se que tais pressupostos, quando plenamente contemplados no ambiente de trabalho, asseguram que o capital intelectual dos programadores está sendo bem gerido, limitando-se tal conclusão às dimensões a que 
se referem cada índice. De acordo com o quadro 5.1, e excluindo-se as repetições, extraem-se, portanto, os seguintes pressupostos acerca da gestão excelente do capital intelectual dos programadores de software:

1. Ter boa formação

Engloba aspectos tais como: capacidade de adaptação a variadas situações no trabalho, conhecimentos, competências e habilidades, sejam de natureza técnica ou não, e que contribuem para aumentar a eficiência do programador em suas funções profissionais

\section{Ter boa experiência}

Leva em consideração o tempo de trabalho na função de programador, que potencialmente contribui para a eficiência do profissional.

3. Ter seu C.I. considerado como um passivo

A instituição que considera o capital intelectual de seus programadores como algo que aumenta o seu balanço patrimonial, ao contrário do conceito de goodwill, estará gerindo de forma excelente o capital intelectual desses profissionais quanto a este aspecto, considerando-o assim um passivo da empresa, e não um custo.

4. Ter acesso a um bom sistema de conhecimento organizacional

Leva em consideração a existência e o acesso dos programadores a um sistema de retenção e consulta ao conhecimento organizacional, que tenha por objetivo reter o conhecimento gerado pelas atividades profissionais de seus funcionários.

5. Ter um bom treinamento

A empresa que proporciona condições adequadas de treinamento e atualização profissional de seus programadores estará gerindo de melhor seu capital 
intelectual, contribuindo para aumentar a eficiência do programador em suas funções profissionais

6. Ter poder de decisão (empowerment)

Relaciona-se com o fato de o programador ter ou não a força política suficiente dentro de seu ambiente de trabalho para tomar decisões que afetem diretamente o produto de seu trabalho.

7. Ter satisfação no trabalho

Engloba aspectos como o momento profissional e a remuneração do programador.

8. Ter motivação para o trabalho

Leva em consideração a busca pela qualidade do produto de seu trabalho e o comprometimento do programador com o seu empregador atual.

9. Ter baixa rotatividade

Considera que quanto menos o programador muda de emprego, maior é a qualidade com que seu capital intelectual é gerido pelos seus empregadores.

10. Ter vocação

Um programador que tem a oportunidade de trabalhar com o que gosta indica uma gestão adequada de seu capital intelectual.

11. Ter acesso a um bom sistema de avaliação ocupacional

Considera que uma empresa deve procurar frequentemente alocar o programador em funções que maximizem suas competências profissionais.

12. Ter contato direto com o cliente

Para ter seu capital intelectual bem gerido, o programador precisa ter canais de contato direto com os clientes que usarão o produto de seu trabalho. 
13. Ter boa interação com os colegas de trabalho

A comunicação e a interação abundantes do programador com seus colegas de trabalho potencialmente contribuem para a eficiência do profissional, indicando uma adequada gestão de seu capital intelectual.

Expostos os 13 pressupostos da gestão excelente do capital intelectual dos programadores, é fundamental esclarecer que, do ponto de vista metodológico do presente trabalho, cada um dos pressupostos têm o mesmo peso e a mesma importância entre si. 


\subsection{Pesquisa de Campo}

A meta da pesquisa de campo consistiu em fazer com que o máximo possível de programadores, de Brasil e Canadá, respondessem o questionário. Durante o período de junho/2011 até setembro/2011 o questionário ficou disponibilizado na internet, de modo a facilitar o acesso e a agilizar o processo, além de garantir a maximização das respostas válidas, no sentido de se evitar que o instrumento de coleta seja parcial ou incorretamente preenchido. Foi utilizado como ferramenta o website "Survey Dox" ( $\underline{\text { www.surveydox.com) }}$, que oferece o serviço de construção e publicação de questionários eletrônicos na internet, além da coleta das respostas e da geração de gráficos e estatísticas, inclusive com o cruzamento de todas as questões entre si.

Para tanto, foi levantado o maior número possível de endereços eletrônicos de empresas e de profissionais de tecnologia da informação que lidam diretamente com o desenvolvimento de softwares nos dois países, através de consultas a entidades de classe, empresas e instituições de ensino e pesquisa, usando-se a internet como principal ferramenta de comunicação. 


\subsection{Elaboração do Instrumento de Coleta de Dados}

As questões mais simples do instrumento de coleta de dados procuraram definir o perfil básico de cada respondente. As variáveis de perfil são:

- Idade

- Sexo

- Estado civil

- Quantidade de filhos

- Tecnologias de programação dominadas

- Tamanho da equipe de desenvolvedores de software

- Tipo de software produzido

Os 13 pressupostos e seus respectivos índices foram subdivididos em 3 aspectos básicos: Conhecimento \& Formação, Psicossocial e Relações de Trabalho \& Poder. As respostas são, em quase a sua totalidade e com exceção das questões de perfil, relativas a uma escala de intensidades, que varia de zero (discordo totalmente) até 3 (concordo totalmente). Para cada pressuposto/índice foram formuladas 2 questões, sempre na mesma direção lógica, isto é, quanto maior o grau de concordância, mais próximo da gestão excelente do capital intelectual dos programadores a empresa empregadora estará.

O quadro a seguir lista as questões propostas para o instrumento de coleta de dados, no sentido de se atribuir intensidades para cada um dos 13 índices de gestão do capital intelectual, gerados a partir dos seus pressupostos correspondentes: 
Tabela 4 - Elaboração do Instrumento de Coleta

\begin{tabular}{|c|c|c|c|c|}
\hline $\begin{array}{l}\text { Aspecto } \\
\text { Básico }\end{array}$ & Pressuposto & Autores & Índice & Questões/Assertivas \\
\hline \multirow{4}{*}{ 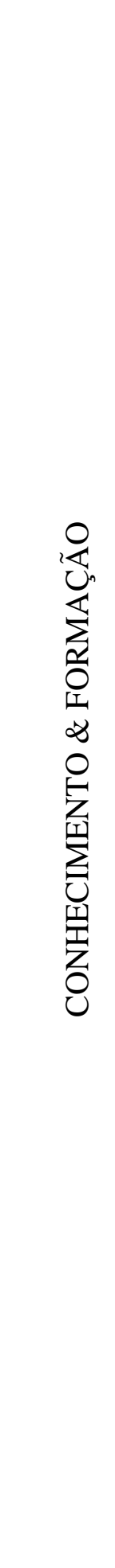 } & Ter boa formação & 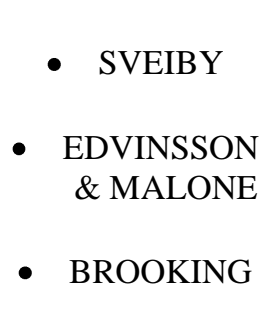 & Índice de Instrução & $\begin{array}{l}\text { 1. Qual a sua } \\
\text { escolaridade máxima? } \\
\text { 2. Em quantos idiomas } \\
\text { você consegue se } \\
\text { comunicar } \\
\text { satisfatoriamente? }\end{array}$ \\
\hline & $\begin{array}{l}\text { Ter um bom } \\
\text { treinamento }\end{array}$ & $\begin{array}{r}\text { EDVINSSON } \\
\& \text { MALONE }\end{array}$ & $\begin{array}{l}\text { Índice de } \\
\text { Treinamento }\end{array}$ & $\begin{array}{l}\text { 3. A minha empresa me } \\
\text { dá excelentes } \\
\text { condições de } \\
\text { treinamento/auto- } \\
\text { aprendizado para } \\
\text { exercer minhas } \\
\text { funções. } \\
\text { 4. A minha empresa atual } \\
\text { paga ou já pagou para } \\
\text { eu estudar. }\end{array}$ \\
\hline & $\begin{array}{l}\text { Ter acesso a um } \\
\text { bom sistema de } \\
\text { conhecimento } \\
\text { organizacional }\end{array}$ & $\begin{array}{l}\text { - } \quad \text { SVEIBY } \\
\text { - } \quad \text { BROOKING } \\
\text { - } \quad \text { STEWART }\end{array}$ & $\begin{array}{l}\text { Índice do Sistema } \\
\text { de Conhecimento } \\
\text { Organizacional }\end{array}$ & $\begin{array}{l}\text { 5. Tenho pleno acesso às } \\
\text { informações de que } \\
\text { preciso para o } \\
\text { desempenho de minhas } \\
\text { funções. } \\
\text { 6. Os softwares que } \\
\text { planejo ou desenvolvo } \\
\text { ficam fartamente } \\
\text { documentados. }\end{array}$ \\
\hline & $\begin{array}{l}\text { Ter acesso a um } \\
\text { bom sistema de } \\
\text { avaliação } \\
\text { ocupacional }\end{array}$ & - BROOKING & Índice Ocupacional & $\begin{array}{l}\text { 7. Estou plenamente } \\
\text { satisfeito com as } \\
\text { funções e atividades } \\
\text { que exerço atualmente. } \\
\text { 8. A empresa se preocupa } \\
\text { constantemente em me } \\
\text { alocar em atividades } \\
\text { nas quais tenho maior } \\
\text { aptidão. }\end{array}$ \\
\hline
\end{tabular}




\begin{tabular}{|c|c|c|c|c|}
\hline $\begin{array}{l}\text { Aspecto } \\
\text { Básico }\end{array}$ & Pressuposto & Autores & Índice & Questões/Assertivas \\
\hline \multirow{4}{*}{ 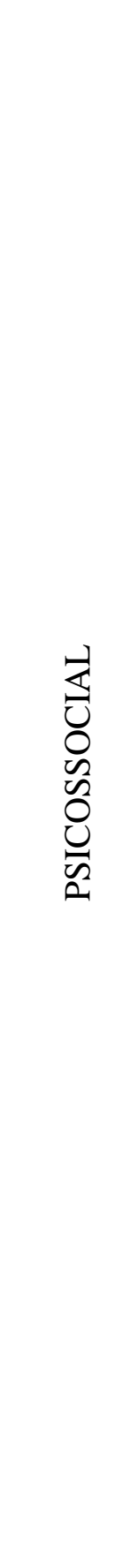 } & $\begin{array}{l}\text { Ter satisfação no } \\
\text { trabalho }\end{array}$ & $\begin{array}{r}\text { EDVINSSON } \\
\text { \& MALONE }\end{array}$ & Índice de Satisfação & $\begin{array}{l}\text { 9. Estou plenamente } \\
\text { satisfeito com o meu } \\
\text { momento profissional. } \\
\text { 10. Estou plenamente } \\
\text { satisfeito com minha } \\
\text { remuneração atual. }\end{array}$ \\
\hline & $\begin{array}{l}\text { Ter motivação para } \\
\text { o trabalho }\end{array}$ & $\begin{array}{r}\text { EDVINSSON } \\
\text { \& MALONE }\end{array}$ & Índice Motivacional & $\begin{array}{l}\text { 11. Desejo muito mudar } \\
\text { de empresa ou de } \\
\text { profissão nos } \\
\text { próximos } 12 \text { meses. } \\
\text { 12. Procuro } \\
\text { constantemente } \\
\text { encontrar formas de } \\
\text { melhorar o produto de } \\
\text { meu trabalho. }\end{array}$ \\
\hline & Ter vocação & - BROOKING & Índice Vocacional & $\begin{array}{l}\text { 13. Sempre desejei } \\
\text { trabalhar na área em } \\
\text { que atuo atualmente. } \\
\text { 14. Costumo desenvolver } \\
\text { softwares } \\
\text { desvinculado do } \\
\text { trabalho. }\end{array}$ \\
\hline & $\begin{array}{l}\text { Ter boa interação } \\
\text { com os colegas de } \\
\text { trabalho }\end{array}$ & - STEWART & $\begin{array}{l}\text { Índice de } \\
\text { Coleguismo }\end{array}$ & $\begin{array}{l}\text { 15. A relação que tenho } \\
\text { com meus colegas de } \\
\text { trabalho é excelente. } \\
\text { 16. Participo com muita } \\
\text { freqüência de } \\
\text { confraternizações com } \\
\text { meus colegas de } \\
\text { trabalho. }\end{array}$ \\
\hline
\end{tabular}




\begin{tabular}{|c|c|c|c|c|}
\hline $\begin{array}{l}\text { Aspecto } \\
\text { Básico }\end{array}$ & Pressuposto & Autores & Índice & Questões/Assertivas \\
\hline \multirow{5}{*}{ 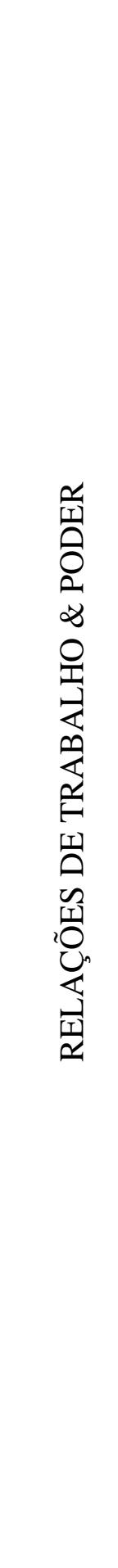 } & $\begin{array}{l}\text { Ter poder de } \\
\text { decisão } \\
\text { (empowerment) }\end{array}$ & 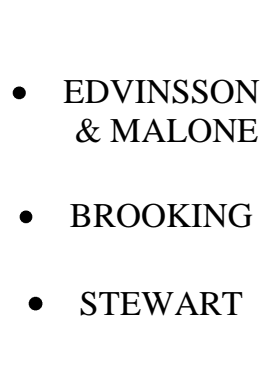 & $\begin{array}{c}\text { Índice de Poder de } \\
\text { Decisão } \\
\text { (empowerment) }\end{array}$ & $\begin{array}{l}\text { 17. Tenho amplo controle } \\
\text { sobre as minhas funções } \\
\text { no trabalho. } \\
\text { 18. Sou constantemente } \\
\text { consultado antes de } \\
\text { decisões importantes } \\
\text { acerca dos projetos em } \\
\text { que participo. }\end{array}$ \\
\hline & $\begin{array}{l}\text { Ter contato direto } \\
\text { com o cliente }\end{array}$ & - STEWART & $\begin{array}{l}\text { Índice de Contato } \\
\text { Direto com Clientes }\end{array}$ & 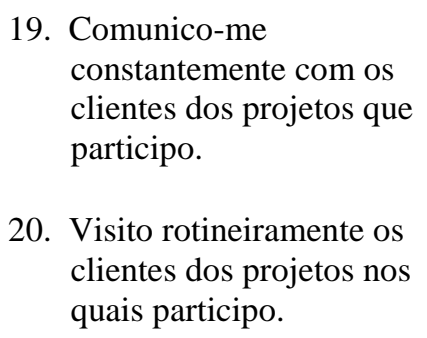 \\
\hline & $\begin{array}{c}\text { Ter baixa } \\
\text { rotatividade }\end{array}$ & $\begin{array}{r}\text { EDVINSSON } \\
\& \text { MALONE }\end{array}$ & $\begin{array}{c}\text { Indice de } \\
\text { Rotatividade }\end{array}$ & $\begin{array}{l}\text { 21. Quantos empregos você } \\
\text { já teve como } \\
\text { programador/analista de } \\
\text { sistemas, contando com } \\
\text { o atual? } \\
\text { 22. Há quanto tempo você } \\
\text { trabalha } \\
\text { profissionalmente como } \\
\text { programador/analista de } \\
\text { sistemas? }\end{array}$ \\
\hline & Ter boa experiência & $\begin{array}{c}\bullet \quad \text { SVEIBY } \\
\text { EDVINSSON } \\
\& \text { MALONE } \\
\text { - BROOKING }\end{array}$ & Índice Hierárquico & $\begin{array}{l}\text { 23. Quantas vezes você já foi } \\
\text { promovido? } \\
\text { 24. Qual é o seu nível } \\
\text { técnico em } \\
\text { análise/desenvolvimento } \\
\text { de sistemas? }\end{array}$ \\
\hline & $\begin{array}{l}\text { Ter seu C.I. } \\
\text { considerado como } \\
\text { um passivo }\end{array}$ & $\begin{array}{c}\cdot \quad \text { SVEIBY } \\
\qquad \quad \text { EDVINSSON } \\
\text { \& MALONE }\end{array}$ & $\begin{array}{l}\text { Índice do Papel } \\
\text { Contábil }\end{array}$ & $\begin{array}{l}\text { 25. Qual é o tipo de seu } \\
\text { vínculo contratual de } \\
\text { trabalho? } \\
\text { 26. Qual foi a sua } \\
\text { remuneração variável no } \\
\text { ano passado? }\end{array}$ \\
\hline
\end{tabular}

Fonte: o autor 
Sendo assim, o instrumento de coleta de dados conterá um total de 36 questões/assertivas autopreenchíveis, sendo que 10 delas procurarão definir o perfil básico dos programadores respondentes, e as demais 26 procurarão investigar com que grau as respostas se aproximam dos pressupostos, elaborados a partir da revisão teórica a respeito do conceito de capital intelectual.

O instrumento de coleta de dados será disponibilizado tanto na língua portuguesa quanto nas línguas inglesa e francesa, contemplando assim os idiomas oficiais do Brasil e do Canadá. 


\section{APRESENTAÇÃO E ANÁLISE DOS DADOS COLETADOS}

Após a construção e divulgação do questionário publicado na Internet, obteve-se um total de 566 profissionais de TI respondentes. Desse total, 31,1\% (176) foram de profissionais que declararam trabalhar no Canadá, e 66,4\% (376) declararam trabalhar no Brasil, além de 2,5\% (14) que declararam trabalhar em outros países.

Figura 2 - País de trabalho dos respondentes

11 - Em qual país você trabalha ou trabalhou como programador/analista de TI?

( 566 respondentes )

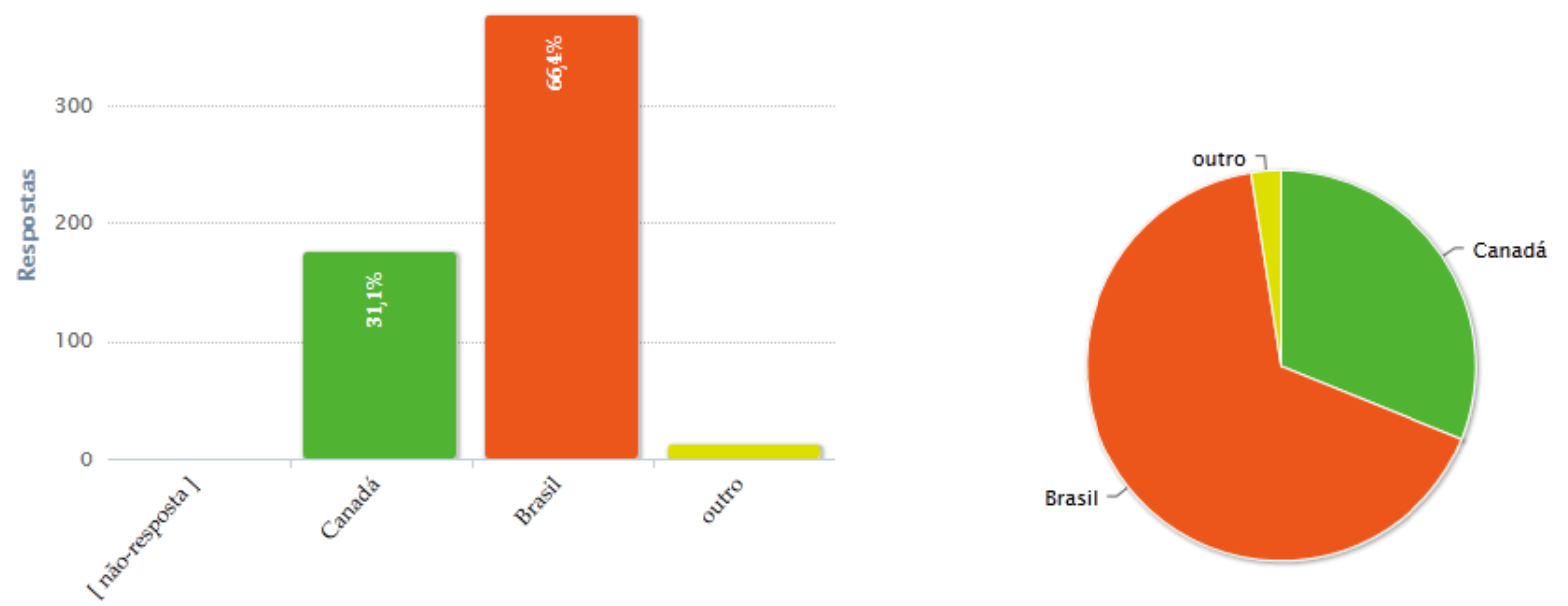

Fonte: www.surveydox.com

No entanto, antes de se analisar propriamente dito os dados da amostra, faz-se necessário descrever o processo de coleta dos e-mails (endereços eletrônicos) dos potenciais respondentes, e o subseqüente disparo das dezenas de milhares de mensagens eletrônicas (ou mensagens de e-mail) a eles.

\subsection{A coleta dos e-mails dos respondentes potenciais}

\subsubsection{Canadá}

Após intensas pesquisas, com o auxílio de serviços de busca, em diversos websites que tratam de empresas e profissionais de TI no Canadá, foram detectados dois websites que disponibilizam gratuitamente grandes bancos de dados com empresas do setor naquele país. 
Como esses websites não disponibilizam todos os e-mails de forma condensada, isto é, os contatos das empresas são exibidos em pequenos lotes a cada página consultada, e como a coleta manual de cada uma das dezenas de milhares de endereços de e-mails seria extremamente lenta e ineficiente, o presente autor, usando-se de suas habilidades e técnicas de programação, criou programas que vasculham automática e exaustivamente tais websites, gravando-os de forma prática e condensada em um banco de dados em seu computador pessoal.

O primeiro website consultado foi o chamado "CanadaIT.com" (www.canadait.com), fundado em 1996 por Peter Standeven, e que se autodefine como "A sua fonte para carreiras, notícias, eventos, capital de risco e informações empresarias da tecnologia da informação canadense". A partir dessa fonte, conseguiu-se assim 24.534 endereços de e-mail de empresas canadenses.

O segundo website consultado é oficial do governo canadense, e se chama "Industry Canada/Industrie Canada" (www.ic.gc.ca). De modo similar ao primeiro website consultado, foi coletado um total de 58.198 e-mails adicionais, totalizando portanto uma soma de 82.734 endereços de e-mail de empresas canadenses.

\subsubsection{Brasil}

De modo similar, foi consultado o website brasileiro "TeleListas" (www.telelistas.net), mantido pelo Grupo Telelistas, que atua há treze anos no mercado, e que se autodefine como "líder no mercado nacional em listas telefônicas impressas e com o maior portal de busca por empresas, serviços, produtos e pessoas na internet brasileira”.

Segundo descrito no website, as listas publicadas pelo grupo "cobrem uma rede de mais de 30 milhões de telefones, atingindo mais de 100 milhões de pessoas de diversas classes sociais". Embora o foco do serviço seja o de fornecer números de telefones de empresas, em diversos dos anúncios também consta o endereço de e-mail, que são o foco do método usado na pesquisa para se solicitar aos profissionais de TI que respondam ao questionário disponibilizado na internet. Usando-se novamente dos programas desenvolvidos pelo autor para esse fim, foi coletado um total de 61.308 endereços de e-mails distintos, dos quais 5.831 eram de empresas diretamente relacionadas com informática. 


\subsection{O disparo das mensagens eletrônicas}

Para disparar os convites, isto é, as mensagens eletrônicas solicitando que respondam o questionário e que o divulgue o link de acesso ao mesmo a todos os profissionais de TI que porventura o destinatário tenha contato, foi utilizado um recurso do SurveyDox, o próprio website utilizado para construir e disponibilizar na internet o questionário da pesquisa.

Com esse recurso, basta informar os endereços de e-mail dos destinatários, definir o assunto e o texto da mensagem, e o próprio sistema se encarrega de dispará-las. Como a pesquisa envolve dois países com idiomas distintos, primeiramente foram carregadas e disparadas, usando-se um texto de convite na língua inglesa, as 82.734 mensagens das empresas canadenses. Após o término desse primeiro disparo foi usado um texto de convite na língua portuguesa aos 61.308 endereços de e-mail das empresas brasileiras, totalizando assim 144.042 mensagens-convite diretas, solicitando que os profissionais de TI respondam o questionário da pesquisa.

Há também que se considerar a esperança de que, conforme solicitado nos convites enviados, as pessoas que leram as mensagens as repassem a outros profissionais de TI que conheçam, propagando dessa forma o link de acesso ao questionário e aumentando ainda mais a base potencial de respondentes. 


\subsection{Perfil dos respondentes}

\subsection{Idade}

Com relação ao perfil de idade, é notável a maior juventude dos respondentes brasileiros em relação aos canadenses. Enquanto 53,7\% dos respondentes brasileiros declararam ter menos de 30 anos de idade, somente $15,4 \%$ dos respondentes canadenses declararam estar nessa faixa etária. Na faixa de 51 ou mais anos, há somente 4,5\% dos brasileiros, enquanto $31,8 \%$ dos canadenses estão nessa faixa.

A tabela comparativa a seguir ilustra, através de três tipos distintos de gráficos, os dados coletados, dando uma dimensão visual da grande diferença no perfil etário entre os profissionais de TI de Canadá e Brasil que responderam à pesquisa. 
Tabela 5 - Perfil etário dos respondentes

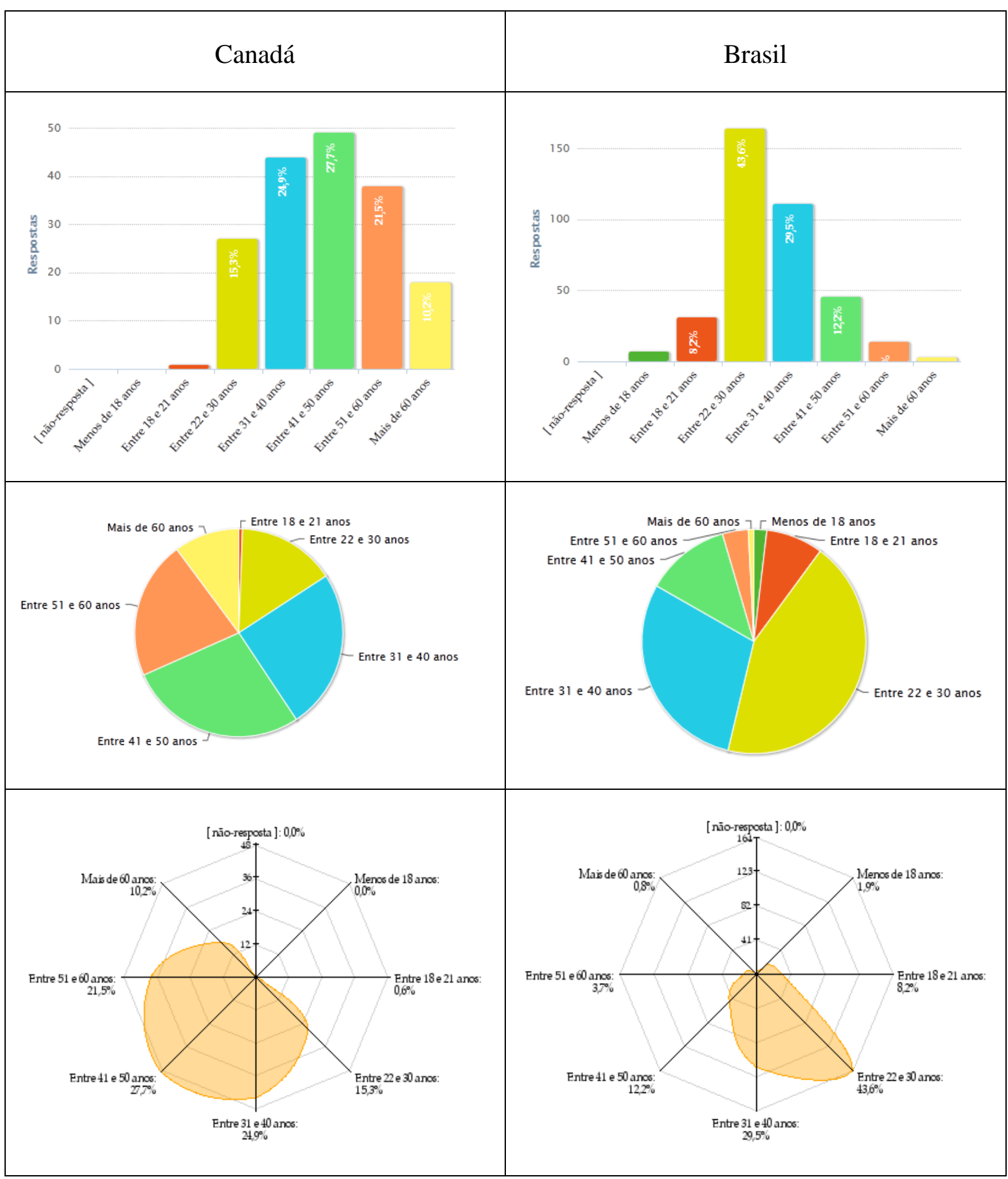

Fonte: o autor

Dos três tipos de gráficos da tabela acima, talvez o que melhor ilustra a diferença no perfil etário seja o tipo "radar" (última linha), notando-se uma maior concentração da mancha no 
canto inferior esquerdo no caso do Canadá, e uma concentração maior da mancha no canto inferior direito, para os respondentes brasileiros. 


\subsection{Sexo}

A distribuição dos sexos foi muito parecida para ambos os países, com grande maioria do sexo masculino:

Tabela 6 - Gênero dos respondentes

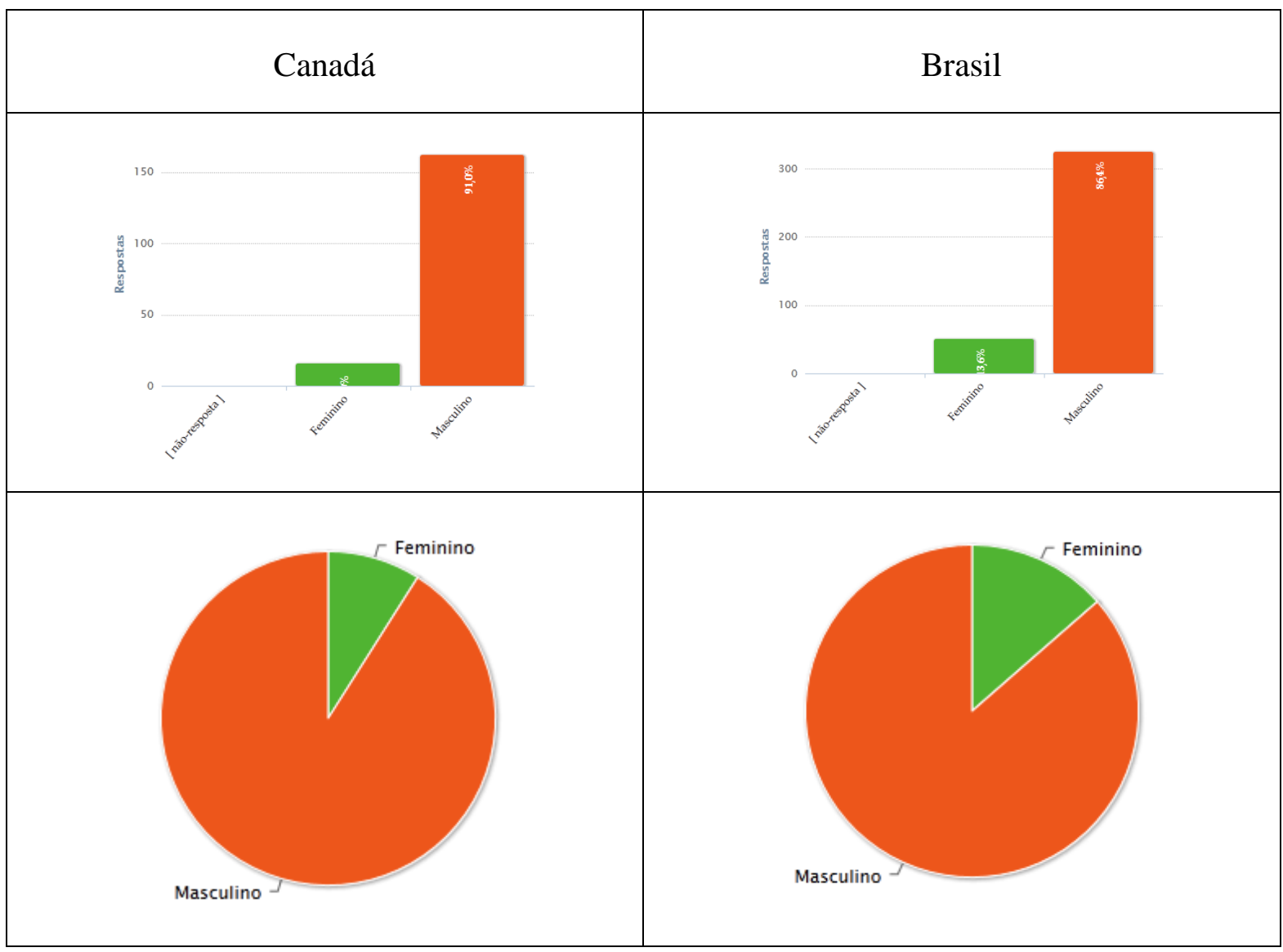

Fonte: o autor

Conforme a tabela acima, no Canadá a proporção de respondentes do sexo masculino foi de $91,0 \%$, enquanto que no Brasil a proporção foi pouco menor, com $86,4 \%$ dos respondentes se declarando do sexo masculino. 


\subsection{Estado civil}

É notável a grande diferença na proporção de solteiros, de 17,4\% no Canadá contra 42,6\% no Brasil, explicada parcialmente pela maior juventude dos respondentes brasileiros. A tabela a seguir apresenta graficamente os resultados coletados na pesquisa de campo:

Tabela 7 - Estado civil dos respondentes

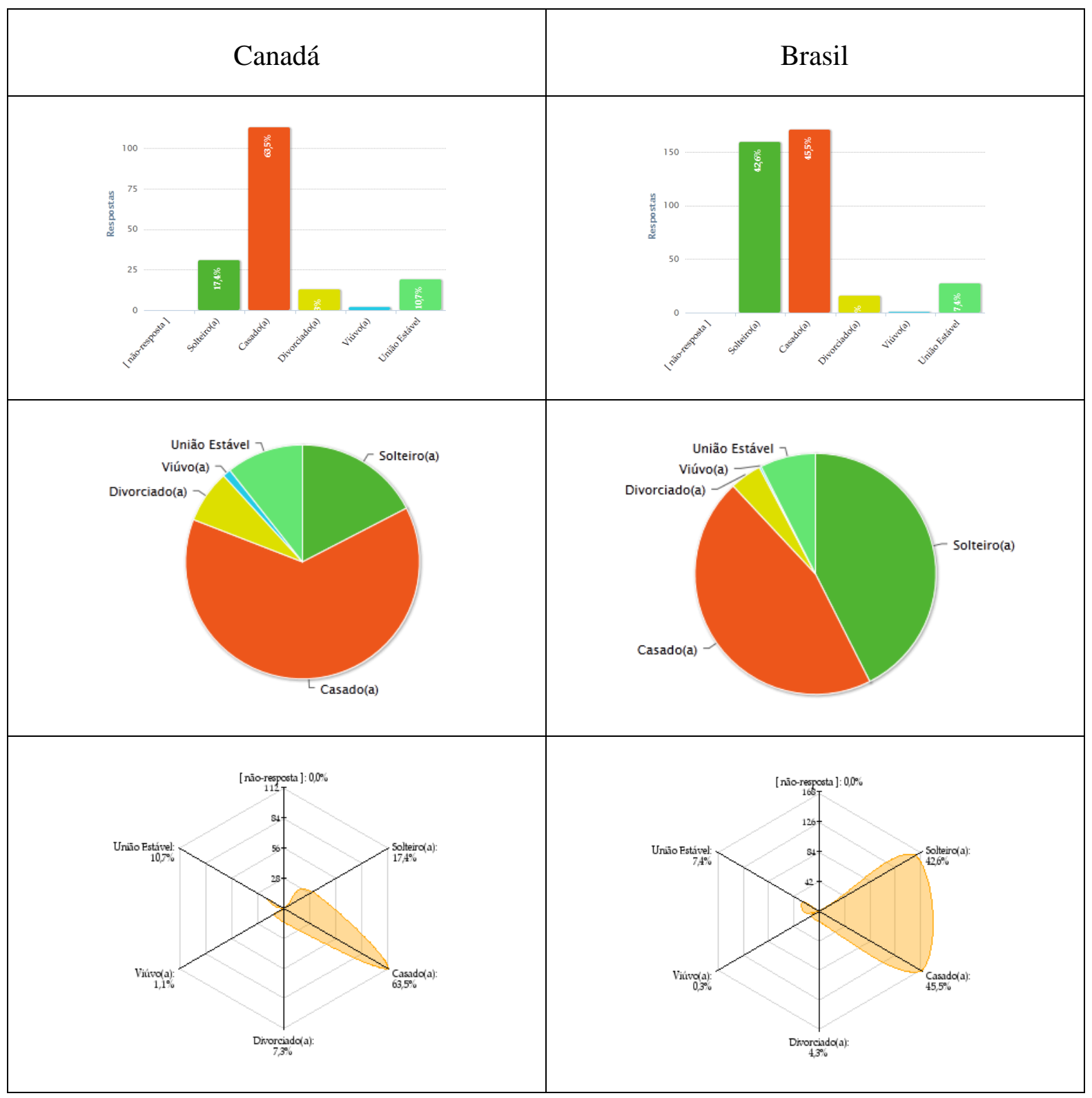

Fonte: o autor 
Outra diferença notável entre os países se refere à proporção da soma das respostas “casado" e "união estável”, que no Canadá é de 74,2\% e no Brasil é de 52,9\%, diferença essa que, assim como nas proporções de solteiros, pode ser parcialmente explicada pela maior juventude dos respondentes brasileiros. 


\subsection{Quantidade de filhos}

A diferença nas quantidades de filhos declaradas pelos respondentes de ambos os países é mais um dado que parece refletir a maior juventude dos respondentes brasileiros. Enquanto apenas $29,2 \%$ dos canadenses declararam não ter filhos, $56,1 \%$ dos brasileiros declararam o mesmo:

Tabela 8 - Quantidade de filhos

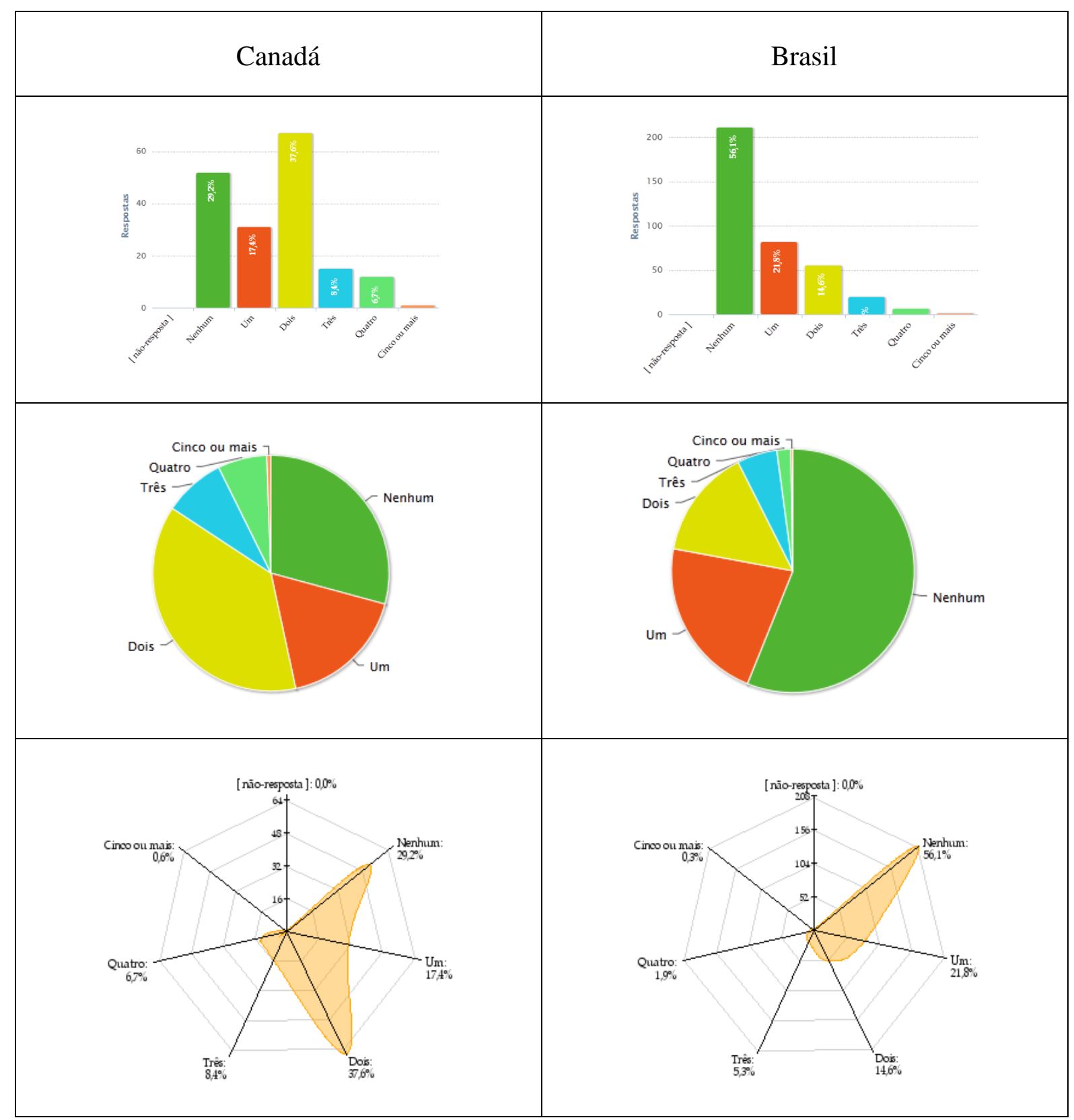

Fonte: o autor 
Já a soma das proporções de quem tem dois ou mais filhos mostra 53,3\% para os respondentes canadenses contra apenas $22,1 \%$ dos brasileiros. 


\subsection{Tecnologias de programação dominadas}

Apesar de apresentarem perfis de idade bastante distintos, os resultados coletados referentes às tecnologias de programação dominadas pelos respondentes de Canadá e Brasil mostraram de modo geral mais semelhanças que diferenças. Dentre as linguagens de programação listadas no questionário, a mais antiga é a linguagem Cobol, que apesar de ter sido criada no final da década de 1950 ainda está em uso em muitas instituições, principalmente bancárias. Poderia-se esperar que a amostra canadense, mais idosa, apresentaria grande diferença de programadores Cobol em relação à brasileira, porém os dados mostram uma ligeira vantagem apenas, com 13,5\% dos canadenses contra $10,4 \%$ dos respondentes brasileiros. Seguem os dados completos:

Tabela 9 - Linguagens de programação dominadas

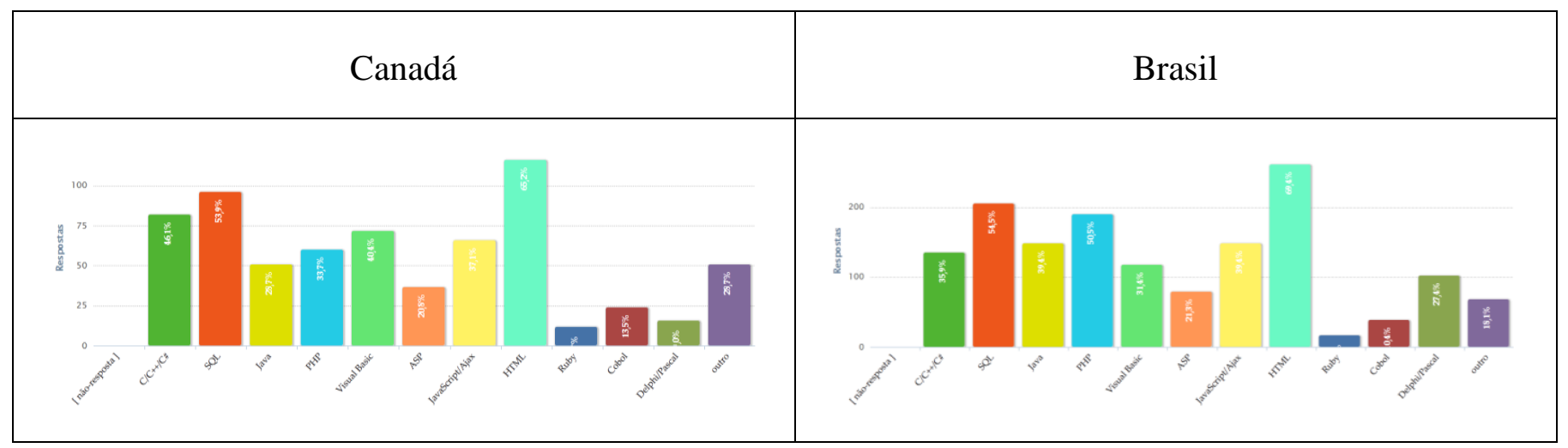

Fonte: $\underline{w w w . s u r v e y d o x . c o m}$

De maneira geral, nota-se mais semelhanças que diferenças entre os respondentes de ambos países. A linguagem HTML, básica para a construção de páginas na internet, é a mais frequente em ambos, seguida pela linguagem universal de bancos de dados SQL, amplamente utilizada em softwares de todo tipo. As diferenças mais notáveis são as linguagens Java e PHP, mais usadas pelos brasileiros, e a linguagem Visual Basic, mais usada pelos canadenses. 


\subsection{Tamanho das equipes de desenvolvedores de software}

Houve grande semelhança entre os países nos dados coletados, com a maioria das equipes de desenvolvedores de software sendo de até 5 programadores/analistas por empresa, sendo $77,0 \%$ para os canadenses e $75,2 \%$ para os respondentes brasileiros:

Tabela 10 - Tamanho das equipes de desenvolvedores de software

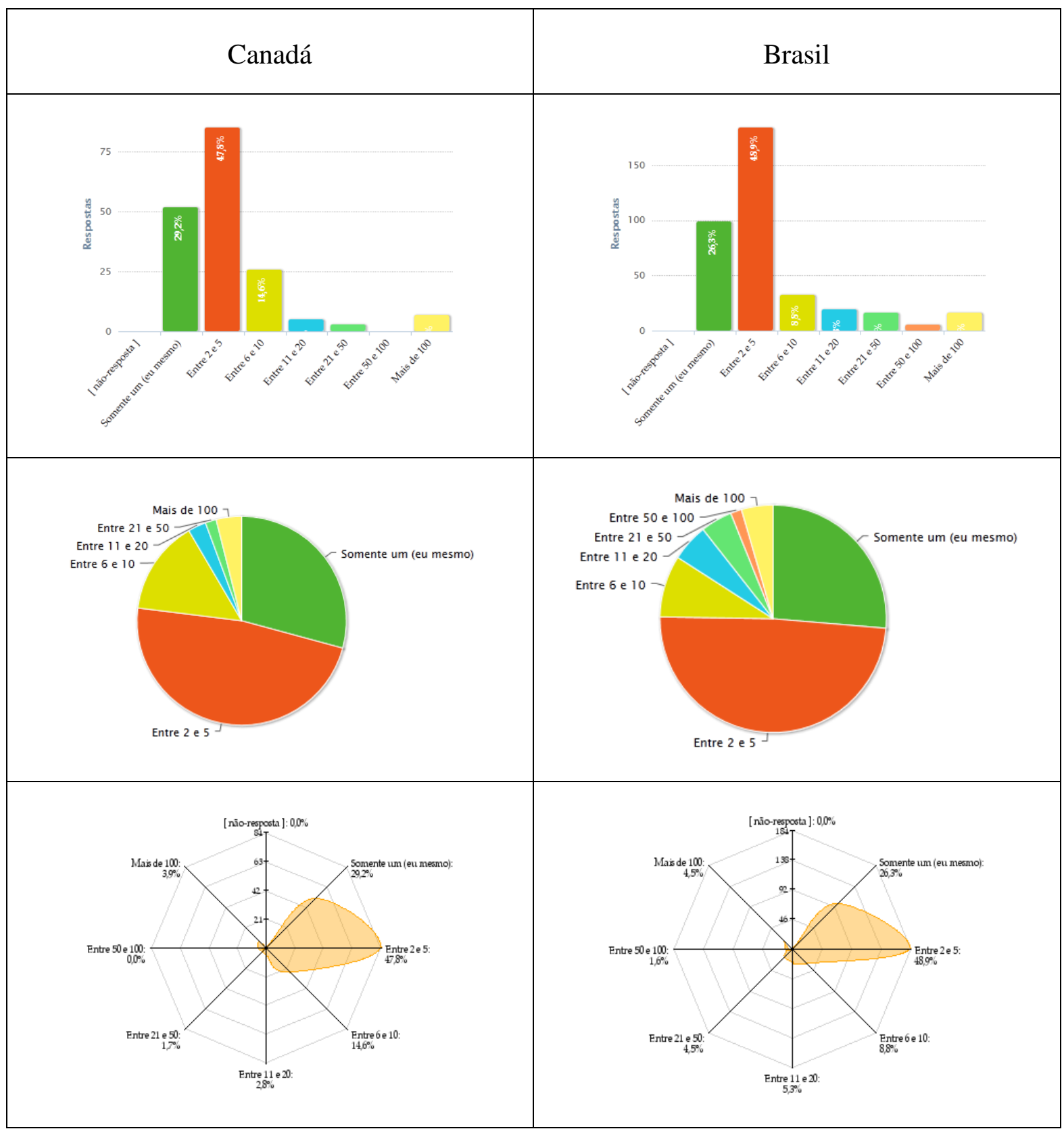

Fonte: o autor 
Uma possível explicação para a grande concentração de equipes com no máximo 5 desenvolvedores é o fato de que instituições com equipes mais numerosas geralmente são grandes empresas que, por diversos motivos, restringem a participação de seus funcionários e terceirizados em pesquisas. Tais motivos incluem códigos de confidencialidade e até mesmo restrições técnicas, como o uso de redes de comunicação internas, sem acesso à mensagens de e-mail externas à instituição. 


\subsection{Tipos de software produzidos}

Na questão sobre o tipos de software produzido pela empresa do respondente, havia três opções: Softwares proprietários, no qual a empresa apenas vende a licença de uso do mesmo a seus clientes ou então produz software para uso interno, softwares sob medida, no qual a empresa vende o serviço de desenvolvimento a seus clientes, e finalmente a terceira opção, "ambos", quando os dois tipos de software são produzidos pela empresa à qual o respondente está associado. Eis os dados coletados: 
Tabela 11 - Tipos de software produzidos

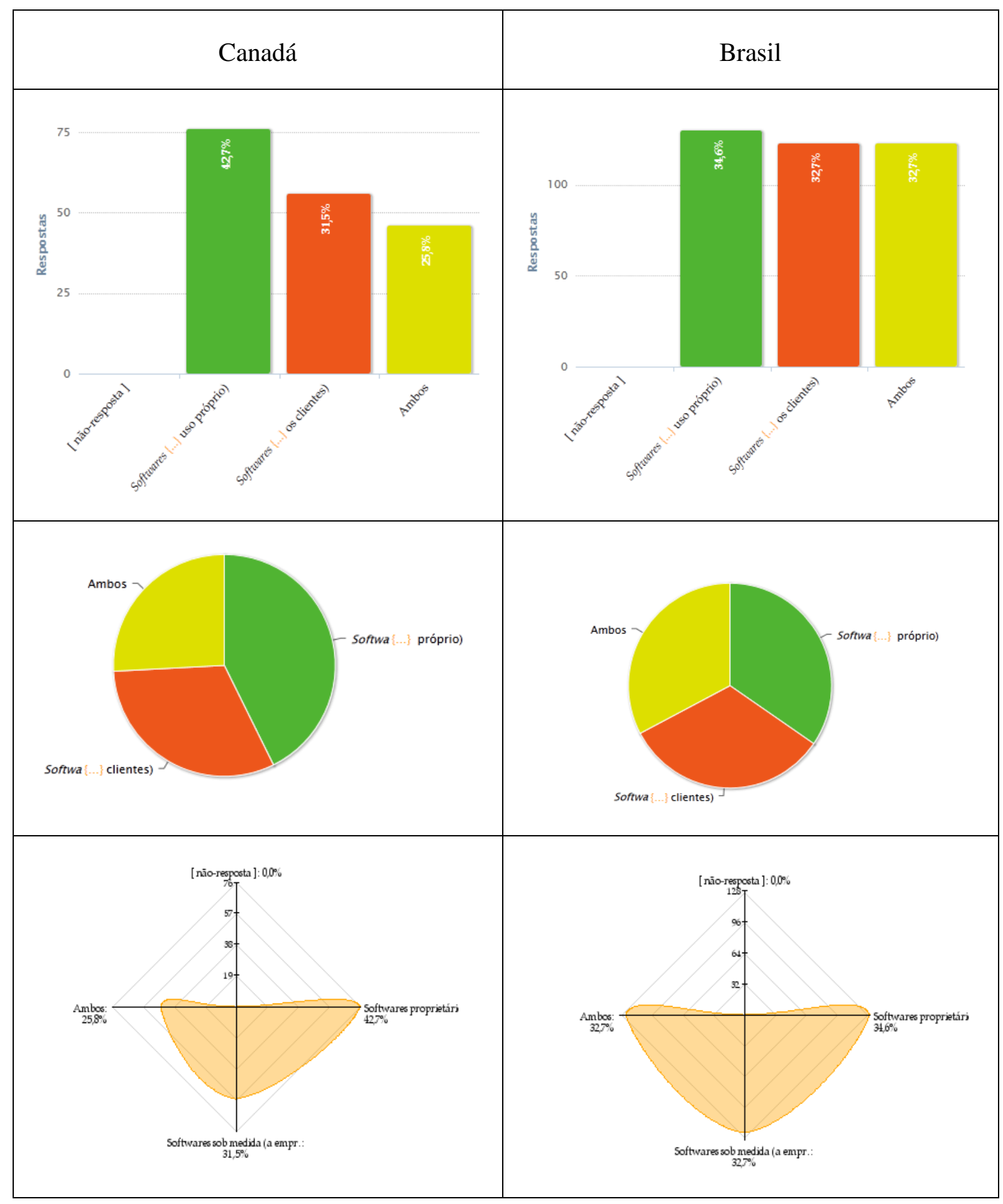

Fonte: o autor

Nota-se que para os respondentes canadenses houve maior incidência $(42,7 \%)$ de empresas que exclusivamente vendem as licenças de uso dos softwares que produzem, ou 
então produzem software para uso interno, contra 34,6\% dos respondentes do Brasil. Com relação às empresas que apenas vendem o serviço de desenvolve softwares houve um resultado muito parecido de 31,5\% no Canadá contra 32,7\% no Brasil. Já nas empresas que produzem ambos os tipos, observa-se maior incidência no Brasil, com 32,7\% ante 25,8\% no Canadá. 


\subsection{Cálculo dos Índices Básicos}

\subsection{O método de cálculo dos índices}

Conforme já explicado no item 6.3 do presente trabalho, e excetuando-se as questões de perfil analisadas acima, em quase sua totalidade as questões que investigam os índice de gestão do capital intelectual dos analistas e programadores de software variam de intensidade zero (discordo totalmente) até a intensidade 3 (concordo totalmente). Para essas questões, o método de cálculo de cada índice correspondente, de acordo com o quadro 6.3, consiste em multiplicar as proporções de respostas coletados pelo questionário com suas respectivas intensidades, e em seguida dividir o valor por 3, calculando-se assim um valor entre zero e 100\% para cada índice básico.

Como exemplo explicativo, suponhamos que para a assertiva "Estou plenamente satisfeito com minha remuneração atual", que corresponde ao "índice de satisfação dos programadores", os respondentes brasileiros tenham respondido na seguinte proporção:

- "discordo totalmente" (intensidade zero): $10 \%$ das respostas

- “discordo parcialmente" (intensidade 1): $40 \%$ das respostas

- "concordo parcialmente" (intensidade 2): $25 \%$ das respostas

- "concordo totalmente" (intensidade 3): $25 \%$ das respostas

Dessa forma, o valor calculado do índice de satisfação relativo à assertiva do exemplo fica: $\frac{0 \times 10 \%+1 \times 40 \%+2 \times 25 \%+3 \times 25 \%}{3}=55 \%$

Lembrando que para cada índice há duas questões associadas, deve-se, finalmente, calcular a média dos resultados calculados para ambas a fim de se obter o resultado final do índice. Supondo-se que para a segunda questão/assertiva o resultado, calculado de forma análoga ao anterior, seja de $75 \%$, tem-se então o valor final para o índice: $\frac{55 \%+75 \%}{2}=65 \%$. 
Em 4 dos 13 índices calculados o método de cálculo foi adaptado, pois havia mais de 4 opções de resposta para cada questão. Eles serão detalhados mais à frente, em momento oportuno. 


\subsection{3. Índice de Instrução}

O índice de instrução, baseado nos autores Sveiby, Edvinsson \& Malone e Brooking, conforme o quadro 6.3, é calculado a partir das respostas de duas questões que, ao contrário da maioria, possuem mais de 4 opções de respostas. Como forma de equipar o índice aos demais, foi feito um ajuste arbitrário das respostas, agrupando-as em quatro conjuntos com intensidades de zero a três, equiparando-se assim à maioria das questões da pesquisa.

Primeira questão do índice: “Qual a sua escolaridade máxima?”.

O agrupamento das 10 opções de resposta possíveis foi o seguinte:

- Intensidade zero:

- Ensino fundamental incompleto

- Ensino fundamental completo

○ Ensino médio incompleto

- Intensidade 1:

- Ensino médio completo

- Ensino superior incompleto

- Intensidade 2:

- Ensino superior completo

○ MBA/Especialização incompleta

- Intensidade 3:

○ MBA/Especialização completa

- Mestrado/doutorado incompleto 
- Mestrado/doutorado completo

Observação: como forma de adaptar algebricamente as respostas "outro", que representaram apenas 3,3\% do total, foi atribuída a intensidade 1,5.

Na comparação Canadá x Brasil, é notável a maior proporção de brasileiros com o ensino superior incompleto, o que permite supor que tal resultado esteja diretamente ligado à maior juventude dos respondentes brasileiros em comparação aos canadenses, conforme visto acima na análise das variáveis de perfil. Vejamos os dados coletados: 
Tabela 12 - Índice de Instrução - primeira questão

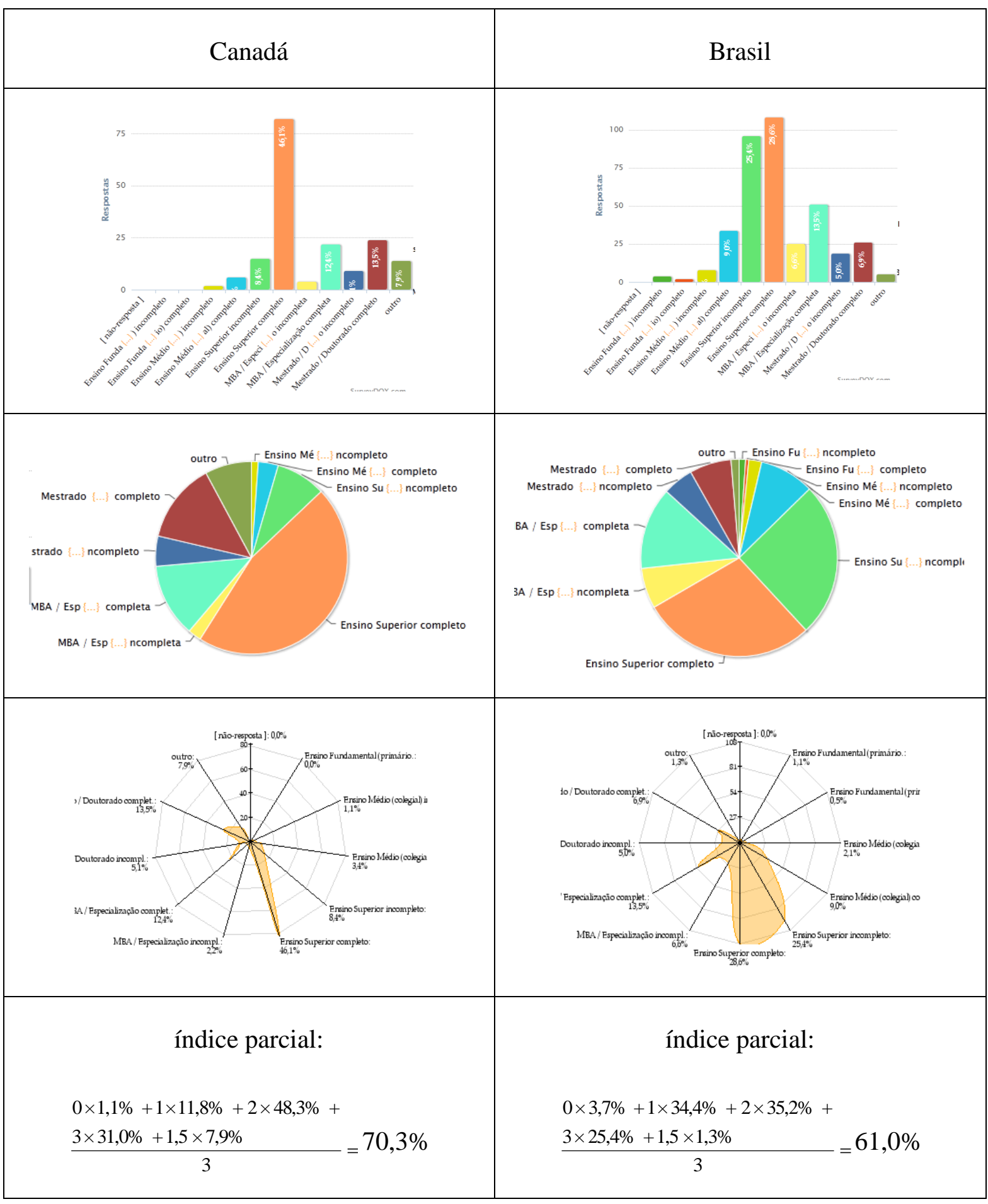

Fonte: o autor 
Nota-se, dessa maneira, uma considerável vantagem de 9,3\% para os respondentes canadenses em relação à escolaridade, o que é coerente com a grande diferença no IDH (índice de desenvolvimento humano) de 2007 entre os dois países, conforme a tabela 3.2.

Segunda questão do índice: "Em quantos idiomas você consegue se comunicar satisfatoriamente?".

O agrupamento das 5 opções de resposta possíveis foi o seguinte:

- Intensidade zero:

○ Um idioma

- Intensidade 1:

- Dois idiomas

- Intensidade 2:

○ Três idiomas

- Intensidade 3:

○ Quatro idiomas

- Cinco ou mais idiomas

A análise das respostas mostra um resultado surpreendente, pois apenas $57,3 \%$ dos respondentes do Canadá, um país oficialmente bilíngüe, declararam dominar dois ou mais idiomas, enquanto $70,4 \%$ dos brasileiros declararam poder se comunicar satisfatoriamente em dois ou mais idiomas: 
Tabela 13 - Índice de Instrução - segunda questão

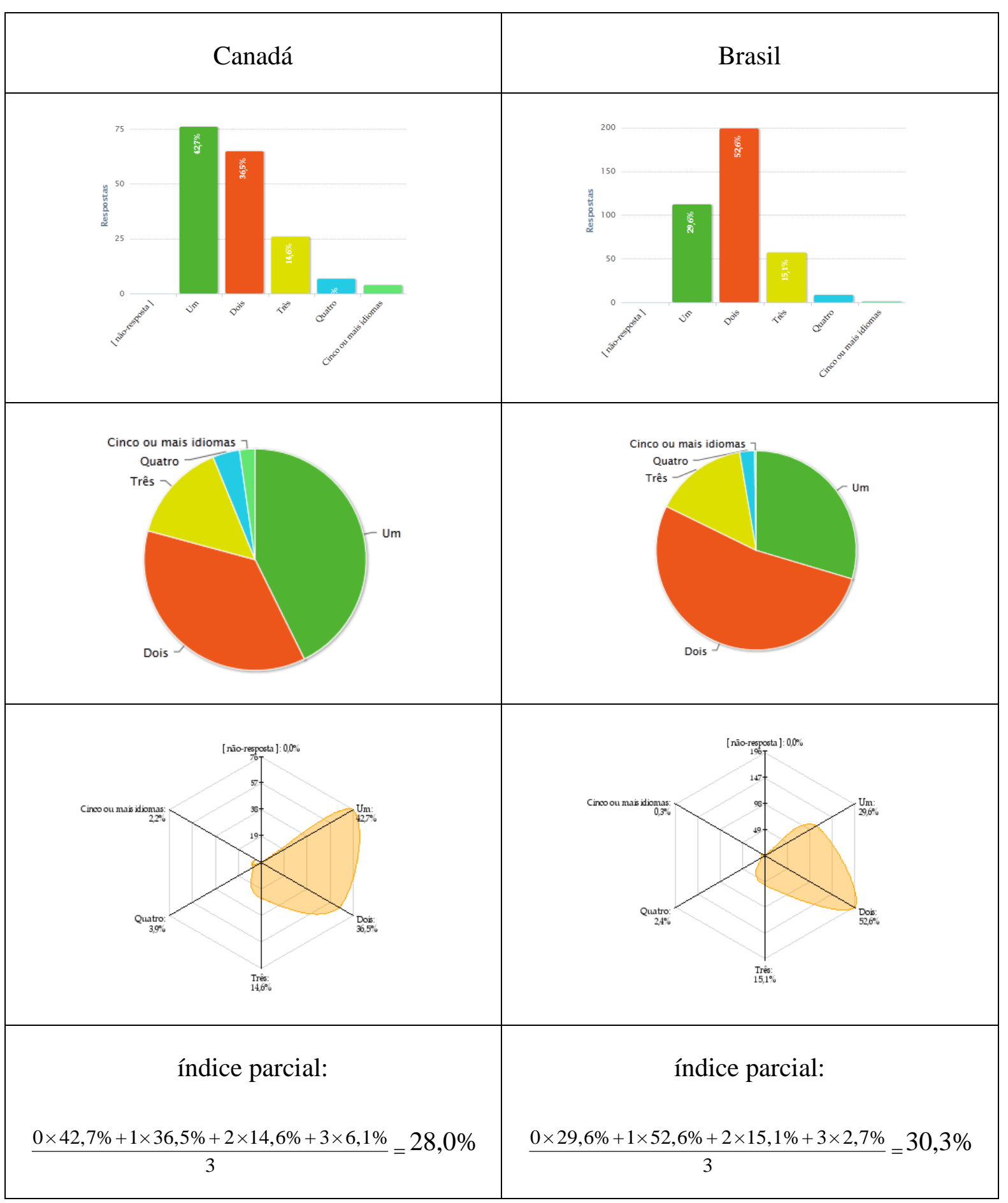

Fonte: o autor 
Temos, portanto, o seguinte resultado para o Índice de Instrução:

\begin{tabular}{|l|c|c|}
\cline { 2 - 3 } \multicolumn{1}{c|}{} & Canadá & Brasil \\
\hline Índice de Instrução: & $\frac{70,3 \%+28,0 \%}{2}=\mathbf{4 9 , 2 \%}$ & $\frac{61,0 \%+30,3 \%}{2}=\mathbf{4 5 , 7 \%}$ \\
\hline
\end{tabular}

Nota-se assim que os respondentes do Canadá tiveram um desempenho ligeiramente superior aos respondentes do Brasil, embora ambos não atingiram a metade da pontuação máxima possível. Com relação à escolaridade, os canadenses apresentaram resultado ligeiramente maior, enquanto que com relação ao domínio de idiomas os brasileiros levaram pequena vantagem. 


\subsection{4. Índice de Treinamento}

Ter um bom treinamento é o pressuposto básico do índice de instrução dos programadores, baseado principalmente em Edvinsson \& Malone, conforme o quadro 6.3. Ele é calculado a partir de duas assertivas, que possuem ambas quatro respostas fechadas possíveis.

Primeira assertiva do índice: "A minha empresa me dá excelentes condições de treinamento/auto-aprendizado para exercer minhas funções".

As respostas possíveis e suas intensidades correspondentes são:

- Intensidade zero:

○ Discordo totalmente

- Intensidade 1:

- Discordo parcialmente

- Intensidade 2:

- Concordo parcialmente

- Intensidade 3:

○ Concordo totalmente

Na comparação Canadá x Brasil, enquanto 82,5\% dos respondentes se declararam concordantes parcial ou totalmente com a assertiva, apenas 69,5\% responderam de forma semelhante. Vejamos os dados coletados: 
Tabela 14 - Índice de Treinamento - primeira assertiva

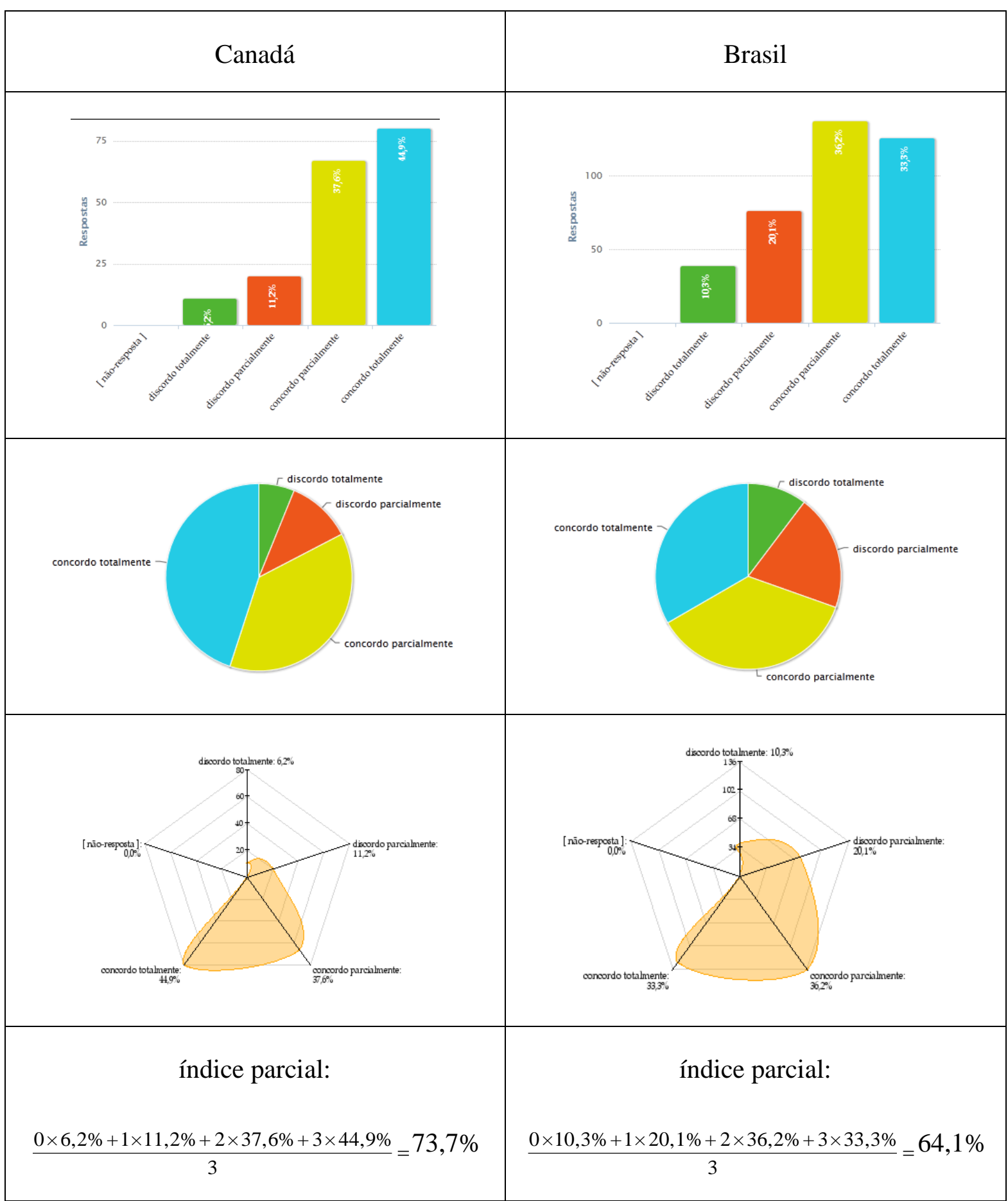

Fonte: o autor

Nota-se, dessa maneira, um desempenho 9,6\% maior para os respondentes canadenses em relação aos brasileiros. 
Segunda assertiva do índice: "A minha empresa atual paga ou já pagou para eu estudar".

As respostas possíveis e suas intensidades correspondentes são:

- Intensidade zero:

- Discordo totalmente

- Intensidade 1:

○ Discordo parcialmente

- Intensidade 2:

○ Concordo parcialmente

- Intensidade 3:

○ Concordo totalmente

Houve grande diferença entre os países acerca dessa assertiva, sendo o desempenho canadense superior ao brasileiro em relação aos concordantes parciais e totais, com $85,4 \%$ de canadenses contra $49,7 \%$ de concordantes brasileiros: 
Tabela 13 - Índice de Treinamento - segunda assertiva

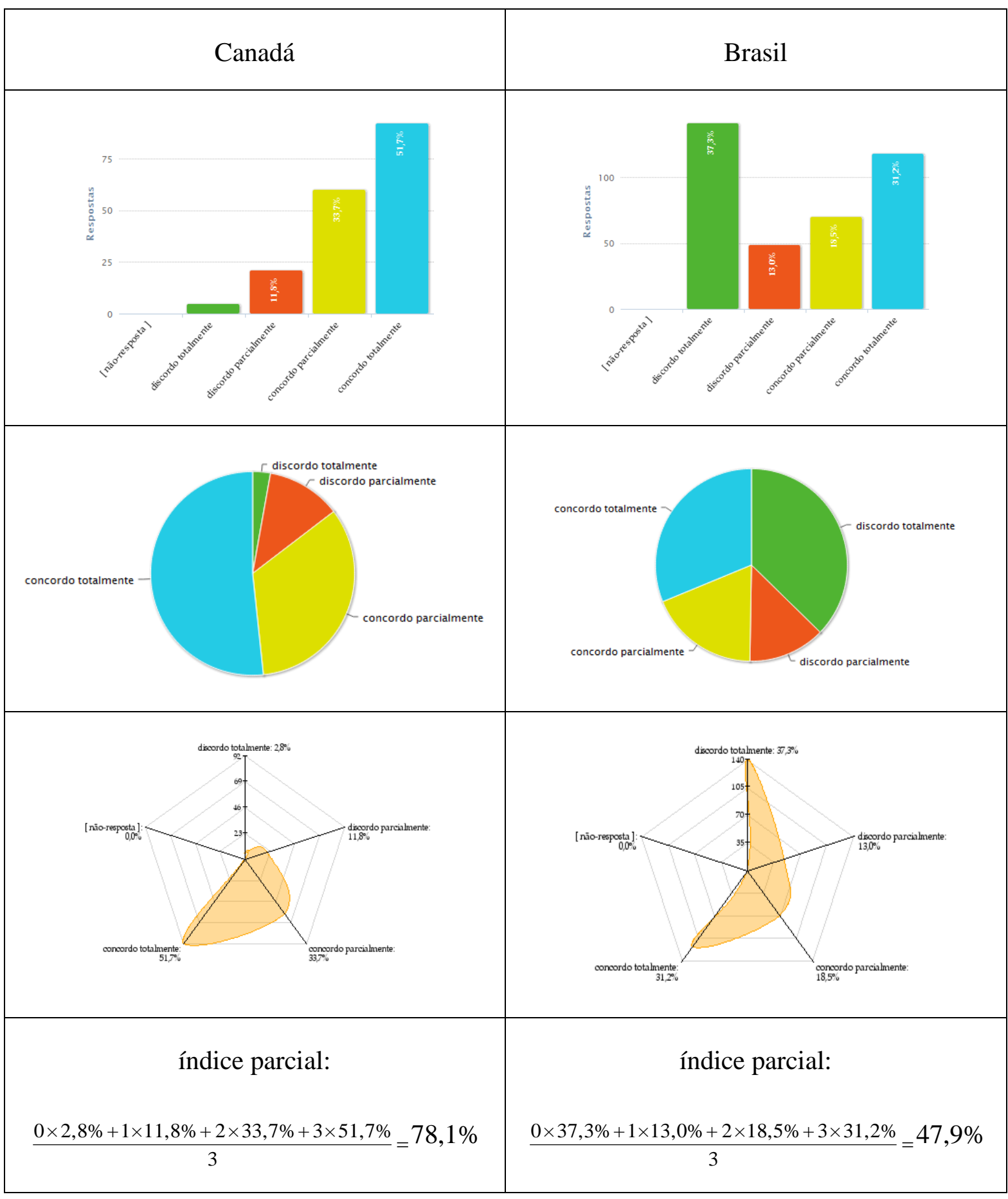

Fonte: o autor 
O Índice de Treinamento teve assim o seguinte valor para cada país:

\begin{tabular}{|l|c|c|}
\cline { 2 - 3 } \multicolumn{1}{c|}{} & Canadá & Brasil \\
\hline Índice de Instrução: & $\frac{73,7 \%+78,1 \%}{2}=\mathbf{7 5 , 9 \%}$ & $\frac{64,1 \%+47,9 \%}{2}=\mathbf{5 6 , 0 \%}$ \\
\hline
\end{tabular}

Os Índices de Treinamento calculados indicam uma considerável diferença de 19,9\% entre o desempenho dos respondentes do Canadá e do Brasil, com destaque para a grande vantagem dos canadenses na assertiva que trata do financiamento de estudos por parte da instituição empregadora. 


\subsection{5. Índice do Sistema de Conhecimento Organizacional}

Um sistema de conhecimento organizacional eficaz permite que o conhecimento produzido em uma instituição fique retido e acessível a todos os profissionais do conhecimento associados a ela, possibilitando uma gestão do capital intelectual que gera vantagem competitiva. Assim como a maioria dos índices do presente trabalho, o índice do sistema de conhecimento organizacional é calculado a partir de duas assertivas, que possuem ambas quatro respostas fechadas possíveis.

Primeira assertiva do índice: "Tenho pleno acesso às informações de que preciso para o desempenho de minhas funções".

As respostas possíveis e suas intensidades correspondentes são:

- Intensidade zero:

- Discordo totalmente

- Intensidade 1:

- Discordo parcialmente

- Intensidade 2:

- Concordo parcialmente

- Intensidade 3:

- Concordo totalmente 
Com relação à soma das concordâncias parcial e total, a proporção dos respondentes brasileiros foi maior, com $82,2 \%$ contra $60,1 \%$ dos canadenses. A seguir estão os gráficos obtidos através dos dados coletados na pesquisa de campo:

Tabela 14 - Índice do Sistema de Conhecimento Organizacional - primeira assertiva

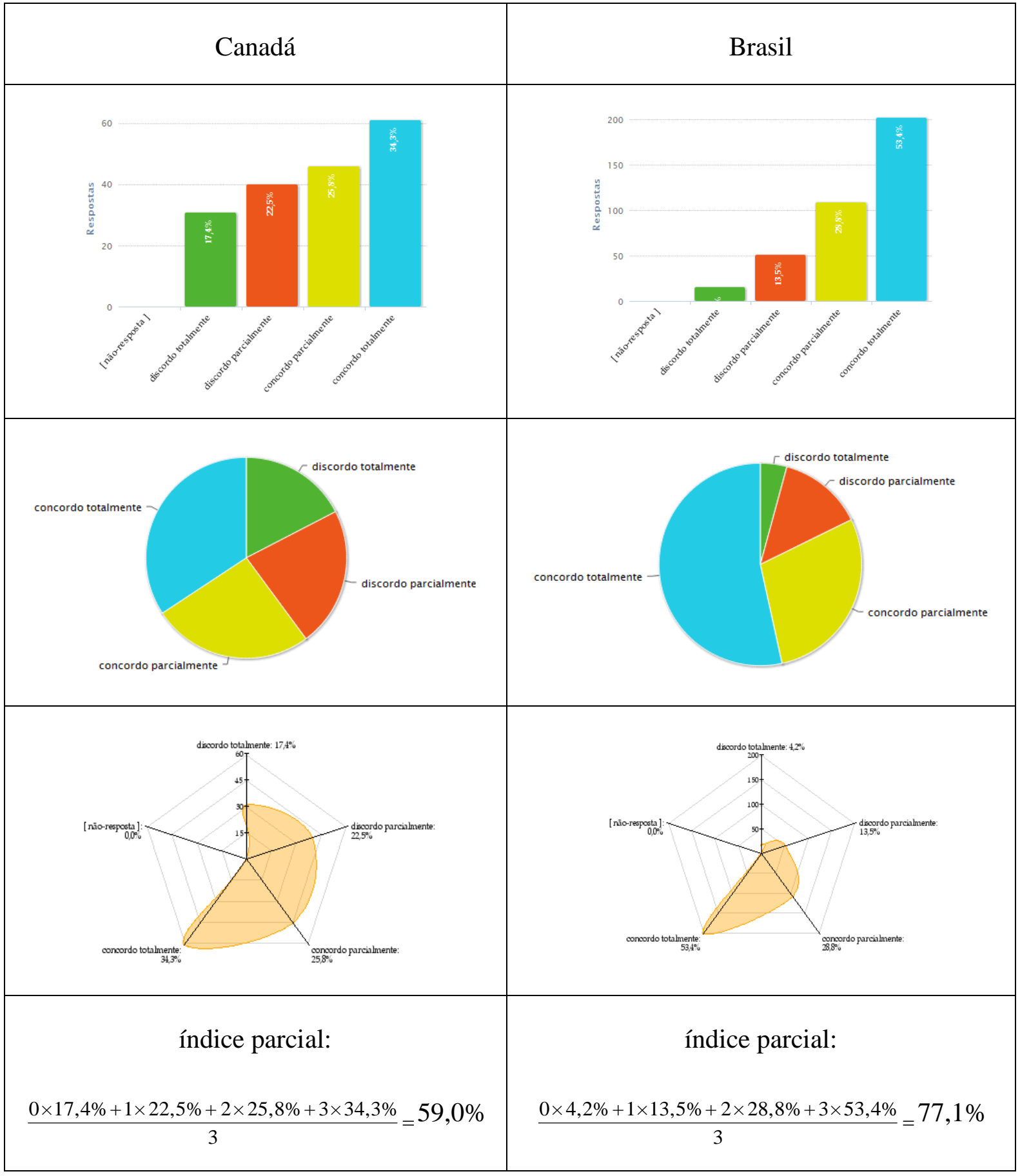

Fonte: o autor 
Nessa primeira assertiva, há uma vantagem de 18,1\% para os respondentes brasileiros em relação às concordâncias parcial e total, acerca do pleno acesso às informações para o desempenho de suas atividades profissionais..

Segunda assertiva do índice: "Os softwares que planejo ou desenvolvo ficam fartamente documentados".

As respostas possíveis e suas intensidades correspondentes são:

- Intensidade zero:

○ Discordo totalmente

- Intensidade 1:

- Discordo parcialmente

- Intensidade 2:

○ Concordo parcialmente

- Intensidade 3:

- Concordo totalmente

Por parte dos respondentes canadenses a concordância parcial ou total foi de $66,9 \%$, enquanto que para os brasileiros a concordância foi menor, com 53,7\% das respostas. A seguir estão os dados coletados: 
Tabela 15 - Índice do Sist. de Conhecimento Organizac. - segunda assertiva

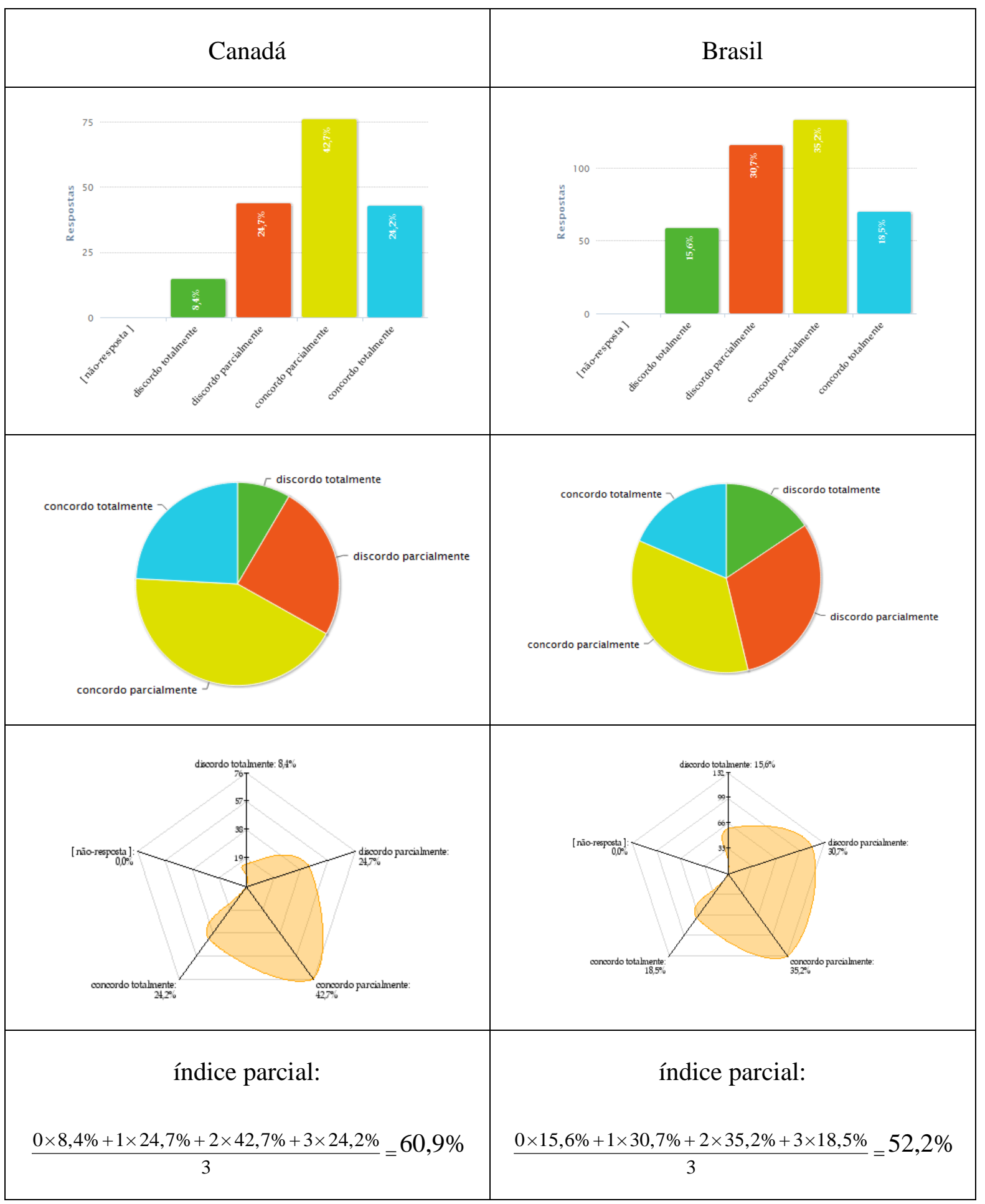

Fonte: o autor

O valor final calculado para o Índice do Sistema de Conhecimento Organizacional para cada país pesquisa é o seguinte: 


\begin{tabular}{|c|c|c|}
\cline { 2 - 3 } \multicolumn{1}{c|}{} & Canadá & Brasil \\
\hline $\begin{array}{c}\text { Índice do Sistema de Conhecimento } \\
\text { Organizacional: }\end{array}$ & $\frac{59,0 \%+60,9 \%}{2}=\mathbf{6 0 , 0 \%}$ & $\frac{77,1 \%+52,2 \%}{2}=\mathbf{6 4 , 7 \%}$ \\
\hline
\end{tabular}

Apesar de na primeira assertiva o desempenho dos respondentes brasileiros ter sido maior, tal vantagem foi diminuída na segunda assertiva, que investiga o quão bem documentados são os softwares desenvolvidos pelo profissional de TI respondente. Dessa forma, apesar de maior para os brasileiros, ainda assim o índice do sistema de conhecimento organizacional calculado para os respondentes canadenses foi ligeiramente menor. 


\subsection{6. Índice Ocupacional}

O índice ocupacional procura medir o quão eficazmente uma instituição consegue alocar as competências de seus empregados em suas atividades profissionais. Assim como a maioria dos índices do presente trabalho, o índice ocupacional é também calculado a partir de duas assertivas, que possuem ambas quatro respostas fechadas possíveis.

Primeira assertiva do índice: "Estou plenamente satisfeito com as funções e atividades que exerço atualmente".

As respostas possíveis e suas intensidades correspondentes são:

- Intensidade zero:

- Discordo totalmente

- Intensidade 1:

- Discordo parcialmente

- Intensidade 2:

- Concordo parcialmente

- Intensidade 3:

- Concordo totalmente 
Com relação à soma das concordâncias parcial e total, o resultado dos respondentes de ambos os países obtiveram maioria, com $84,8 \%$ para os canadenses e 78,0\% para os brasileiros. A seguir estão os gráficos obtidos através dos dados coletados na pesquisa de campo:

Tabela 16 - Índice Ocupacional - primeira assertiva

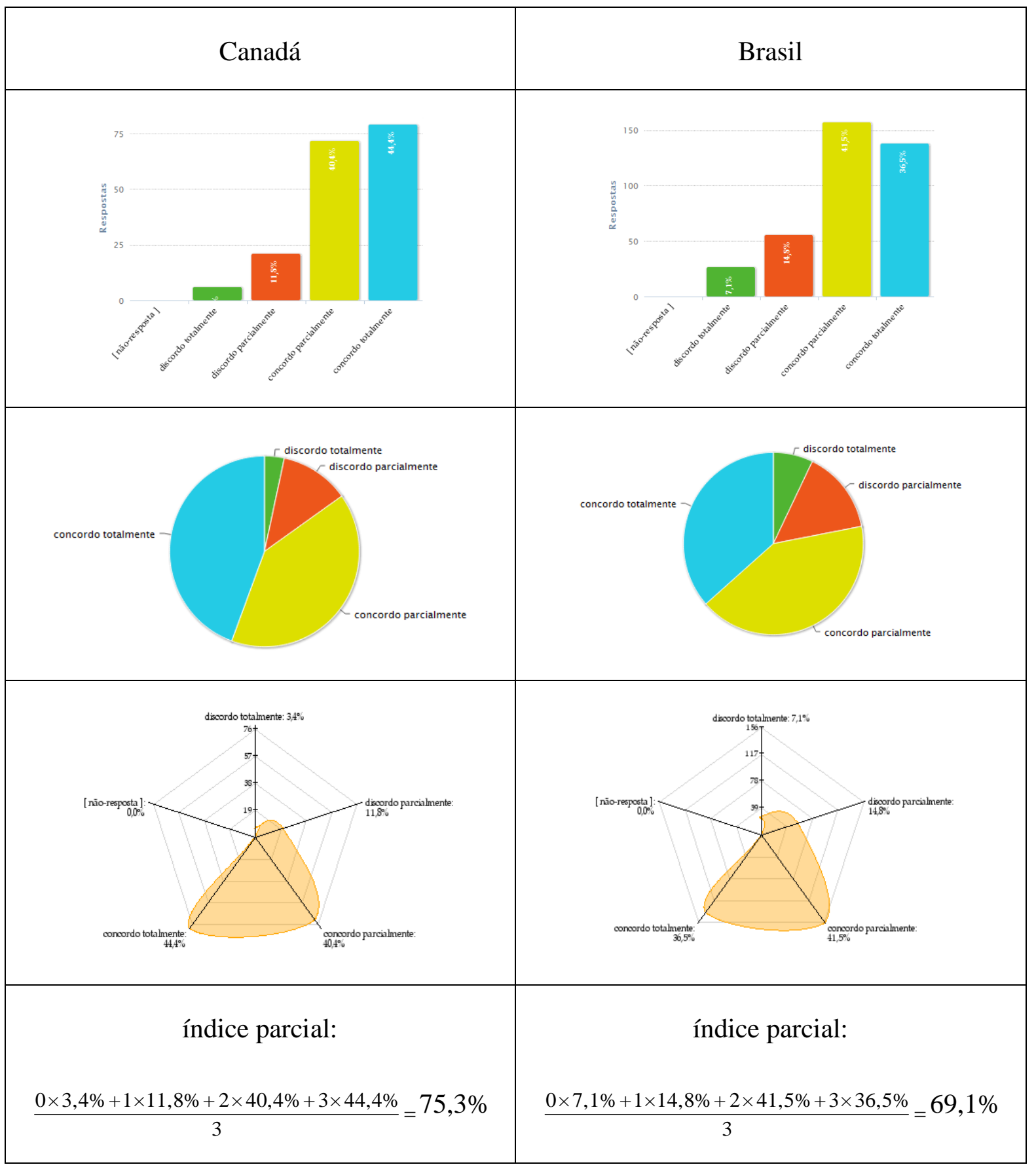

Fonte: o autor 
Segunda assertiva do índice: "A empresa se preocupa constantemente em me alocar em atividades nas quais tenho maior aptidão".

As respostas possíveis e suas intensidades correspondentes são:

- Intensidade zero:

- Discordo totalmente

- Intensidade 1:

○ Discordo parcialmente

- Intensidade 2:

- Concordo parcialmente

- Intensidade 3:

- Concordo totalmente

A concordância parcial ou total para os respondentes do Canadá foi de 49,5\%, enquanto que para os brasileiros a concordância foi maior, com 66,4\% das respostas. Seguem os dados coletados: 
Tabela 17 - Índice Ocupacional - segunda assertiva

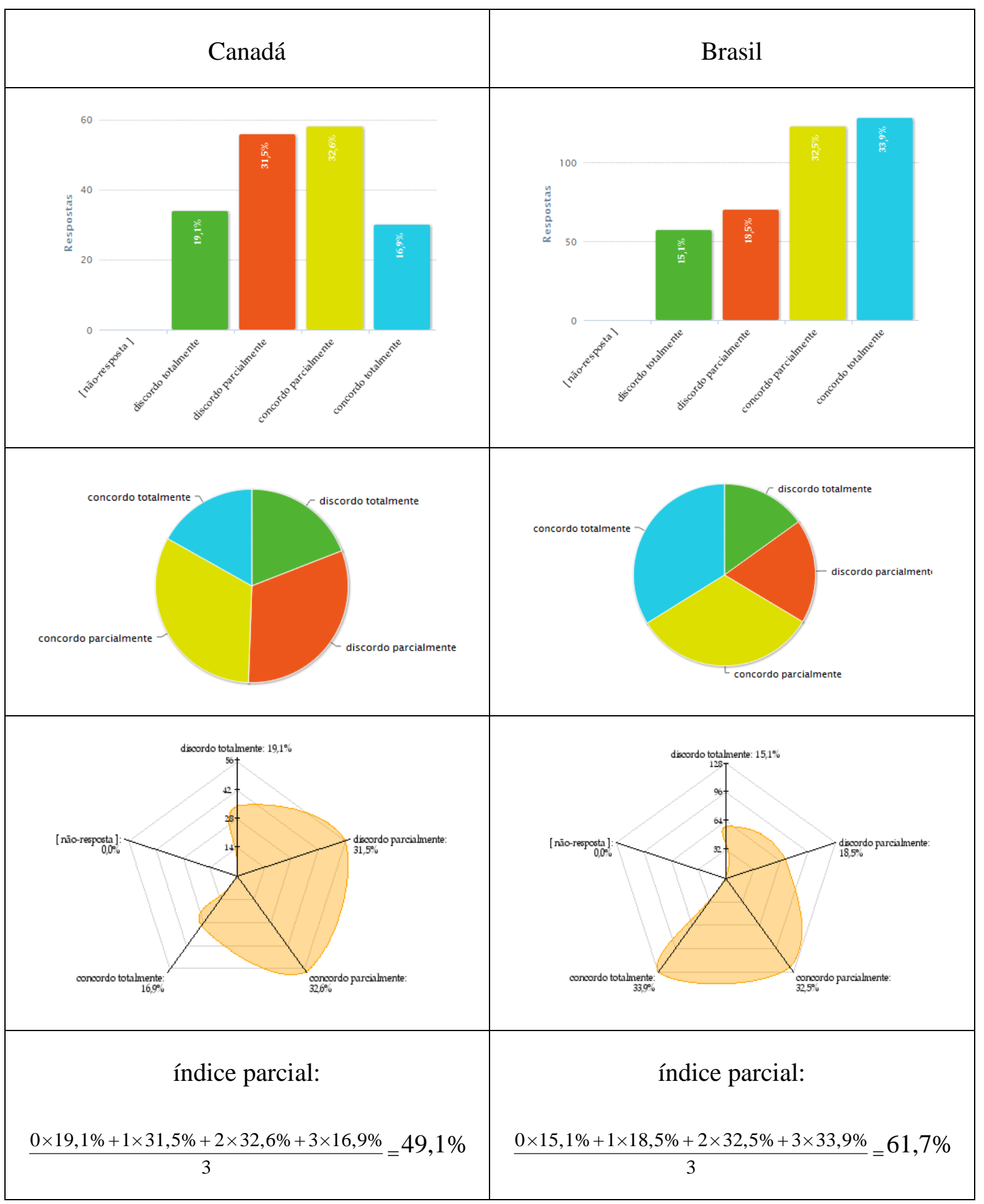

Fonte: o autor

O valor final calculado para o Índice Ocupacional para cada país pesquisa é o seguinte: 


\begin{tabular}{|c|c|c|}
\hline & Canadá & Brasil \\
\hline Índice Ocupacional: & $\frac{75,3 \%+49,1 \%}{2}=\mathbf{6 2 , 2 \%}$ & $\frac{69,1 \%+61,7 \%}{2}=\mathbf{6 5 , 4 \%}$ \\
\hline
\end{tabular}

Apesar de os índices ocupacionais para ambos os países terem sido próximos, com vantagem de apenas 3,2\% para os profissionais de TI brasileiros, na primeira assertiva o índice parcial foi maior para os canadenses, enquanto que para a segunda assertiva os respondentes que declararam trabalhar no Brasil tiveram desempenho superior. 


\subsection{7. Índice de Satisfação}

Conforme já discutido anteriormente, o índice de satisfação dos programadores, fundamentado pela teoria de Edvinsson \& Malone acerca do conceito de capital intelectual, se baseia na avaliação do momento profissional e da remuneração de cada respondente da pesquisa. O índice de satisfação é também calculado a partir de duas assertivas do questionário online, que possuem ambas quatro respostas fechadas possíveis.

Primeira assertiva do índice: "Estou plenamente satisfeito com o meu momento profissional.".

As respostas possíveis e suas intensidades correspondentes são:

- Intensidade zero:

- Discordo totalmente

- Intensidade 1:

- Discordo parcialmente

- Intensidade 2:

○ Concordo parcialmente

- Intensidade 3:

○ Concordo totalmente 
A soma das respostas concordantes parcial e totalmente foi maior para os respondentes do Canadá, com $86,5 \%$ contra $73,1 \%$ para os respondentes brasileiros. Os gráficos obtidos através dos dados coletados na pesquisa de campo são:

Tabela 18 - Índice de Satisfação - primeira assertiva

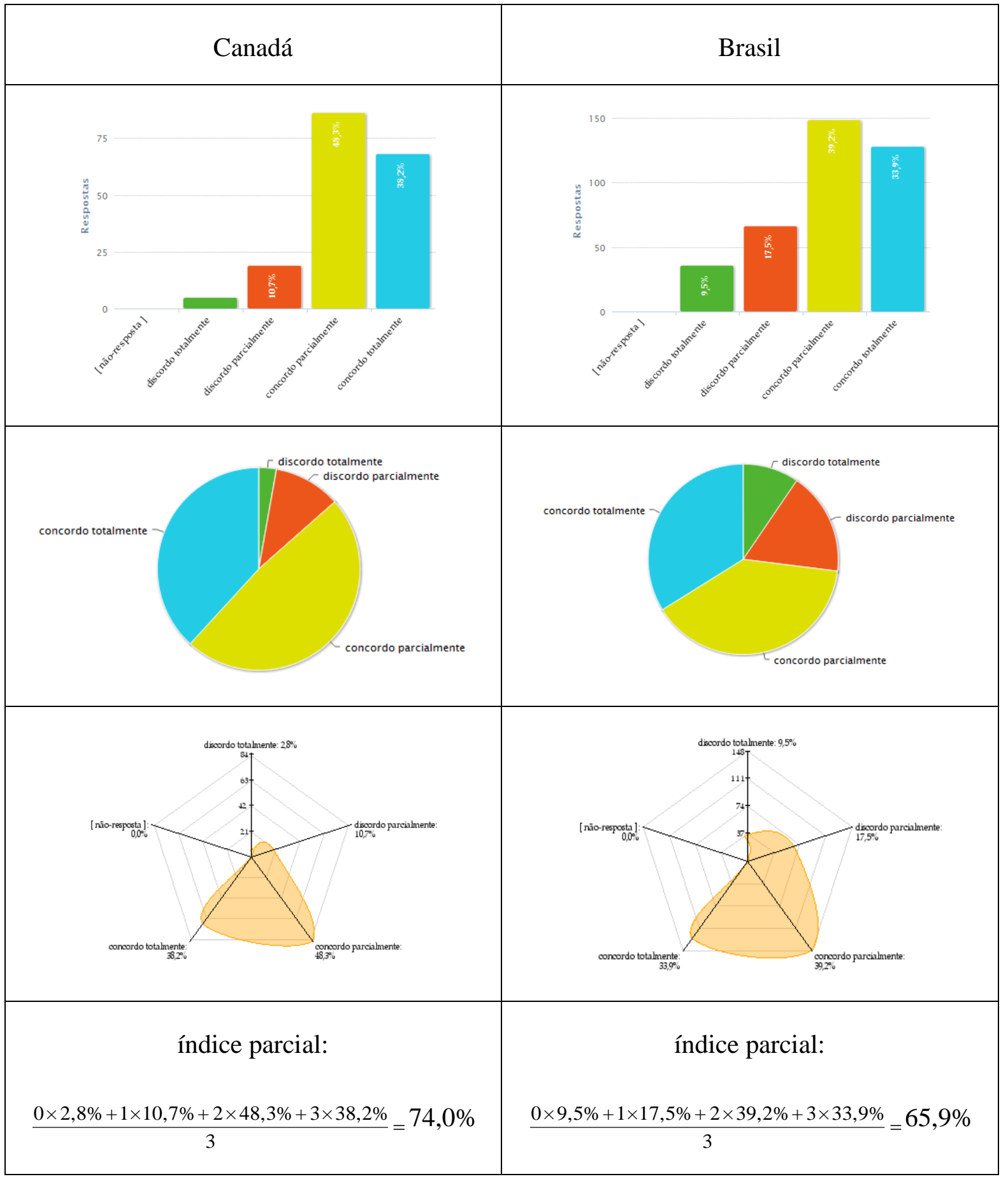

Fonte: o autor 
Os índices parciais obtidos na primeira assertiva mostram que o desempenho dos respondentes canadenses foi maior que o dos brasileiros, em relação ao momento profissional atual por que passam.

Segunda assertiva do índice: "Estou plenamente satisfeito com minha remuneração atual”.

As respostas possíveis e suas intensidades correspondentes são:

- Intensidade zero:

- Discordo totalmente

- Intensidade 1:

○ Discordo parcialmente

- Intensidade 2:

- Concordo parcialmente

- Intensidade 3:

- Concordo totalmente

A concordância parcial ou total em relação a segunda assertiva entre os respondentes do Canadá foi de $74,5 \%$, enquanto que para os brasileiros a concordância foi consideravelmente menor, com 51,6\% das respostas. Seguem os dados coletados: 
Tabela 19 - Índice de Satisfação - segunda assertiva

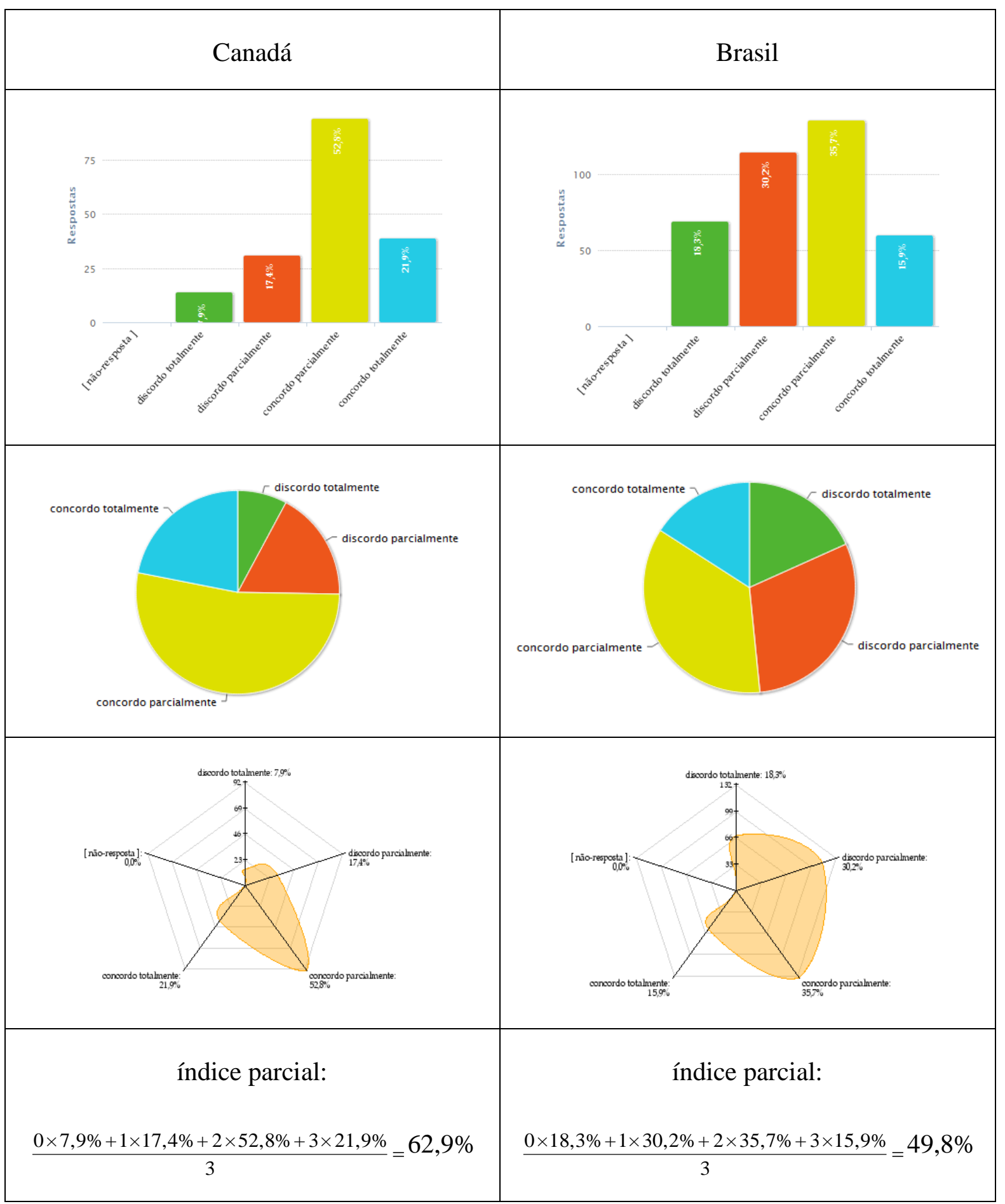

Fonte: o autor

O valor final calculado para o Índice de Satisfação para cada país da pesquisa é, portanto: 


\begin{tabular}{|l|c|c|}
\cline { 2 - 3 } \multicolumn{1}{c|}{} & Canadá & Brasil \\
\hline Índice de Satisfação: & $\frac{74,0 \%+62,9 \%}{2}=\mathbf{6 8 , 5 \%}$ & $\frac{65,9 \%+49,8 \%}{2}=\mathbf{5 7 , 9 \%}$ \\
\hline
\end{tabular}

Os resultados obtidos para o índice sugerem que os respondentes canadenses estão mais satisfeitos profissionalmente que os seus colegas brasileiros, com uma vantagem de 10,6\%. 


\subsection{8. Índice Motivacional}

As assertivas propostas acerca do índice motivacional levam em consideração a busca pela qualidade do produto do trabalho dos respondentes, e também o comprometimento do mesmo em relação à sua atividade profissional. Assim como a maioria dos índices do presente trabalho, ele é calculado a partir de duas assertivas do questionário online, que possuem ambas quatro respostas fechadas possíveis.

Primeira assertiva do índice: "Desejo muito mudar de empresa ou de profissão nos próximos 12 meses".

É importante frisar que essa assertiva tem a peculiaridade de que suas intensidades estão invertidas, isto é, ao contrário da maioria das demais questões e assertivas, a resposta "discordo totalmente" tem a intensidade máxima (3), enquanto que a resposta "concordo totalmente" tem intensidade zero. Sendo assim, as respostas possíveis e suas intensidades correspondentes são:

- Intensidade zero:

- Concordo totalmente

- Intensidade 1:

- Concordo parcialmente

- Intensidade 2:

○ Discordo parcialmente

- Intensidade 3:

- Discordo totalmente 
A soma das respostas discordantes parcial e totalmente foram acima de 50\% para ambos os países, com $75,9 \%$ para os respondentes canadenses e 58,2\% para os brasileiros. Os gráficos obtidos através dos dados coletados na pesquisa de campo são:

Tabela 20 - Índice Motivacional - primeira assertiva

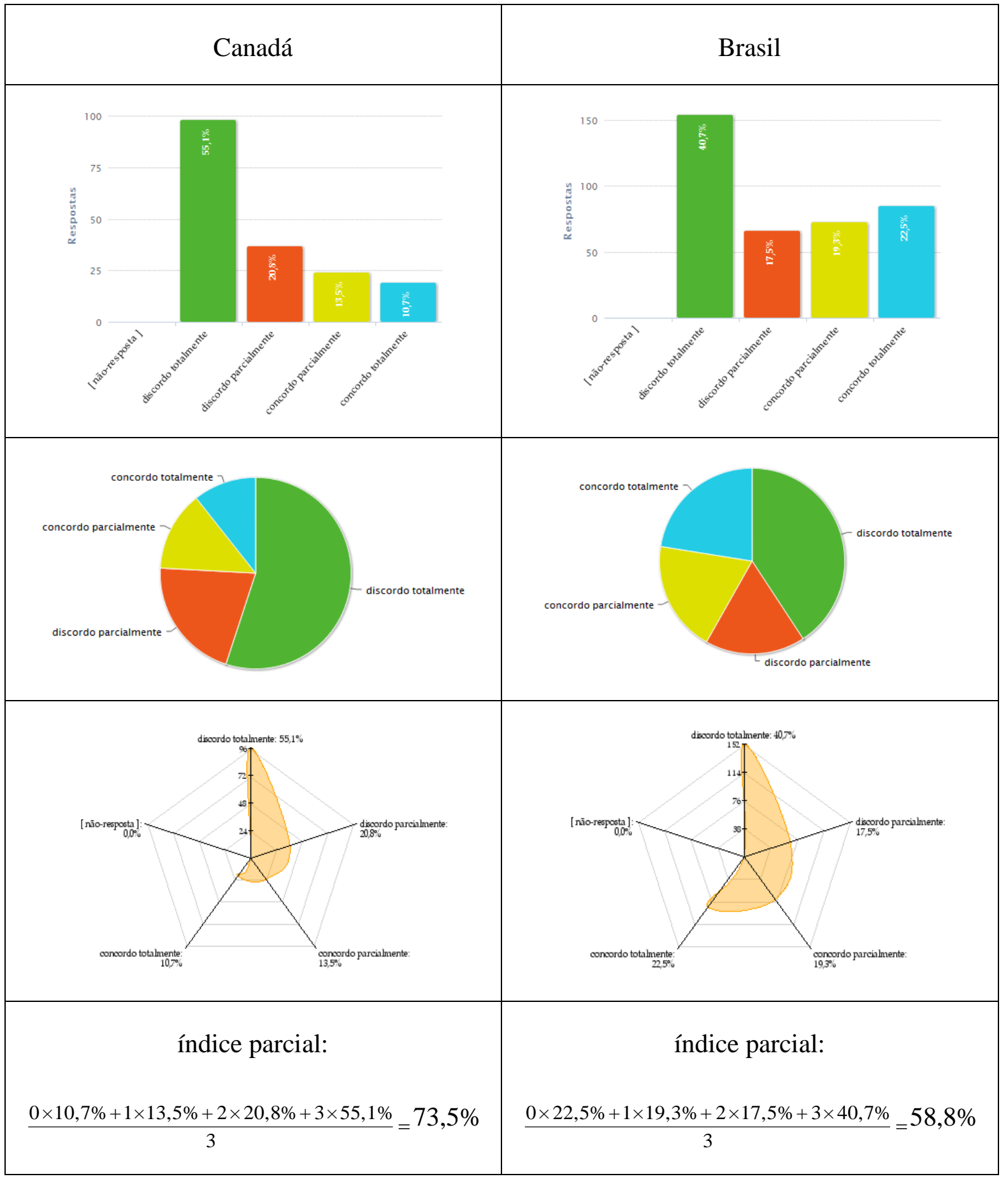

Fonte: o autor 
Os índices parciais obtidos na primeira assertiva mostram que o desempenho dos respondentes canadenses foi maior que o dos brasileiros, considerando-se que quanto menor $\mathrm{o}$ desejo de se mudar de emprego ou profissão nos próximos 12 meses, maior a motivação para o trabalho.

Segunda assertiva do índice: "Procuro constantemente encontrar formas de melhorar o produto de meu trabalho".

As respostas possíveis e suas intensidades correspondentes são:

- Intensidade zero:

○ Discordo totalmente

- Intensidade 1:

○ Discordo parcialmente

- Intensidade 2:

- Concordo parcialmente

- Intensidade 3:

- Concordo totalmente

A concordância parcial ou total em relação a segunda assertiva para ambos os países foi muito alta, com $97,8 \%$ para os canadenses e $97,4 \%$ para os respondentes brasileiros. Seguem os dados coletados: 
Tabela 21 - Índice Motivacional - segunda assertiva

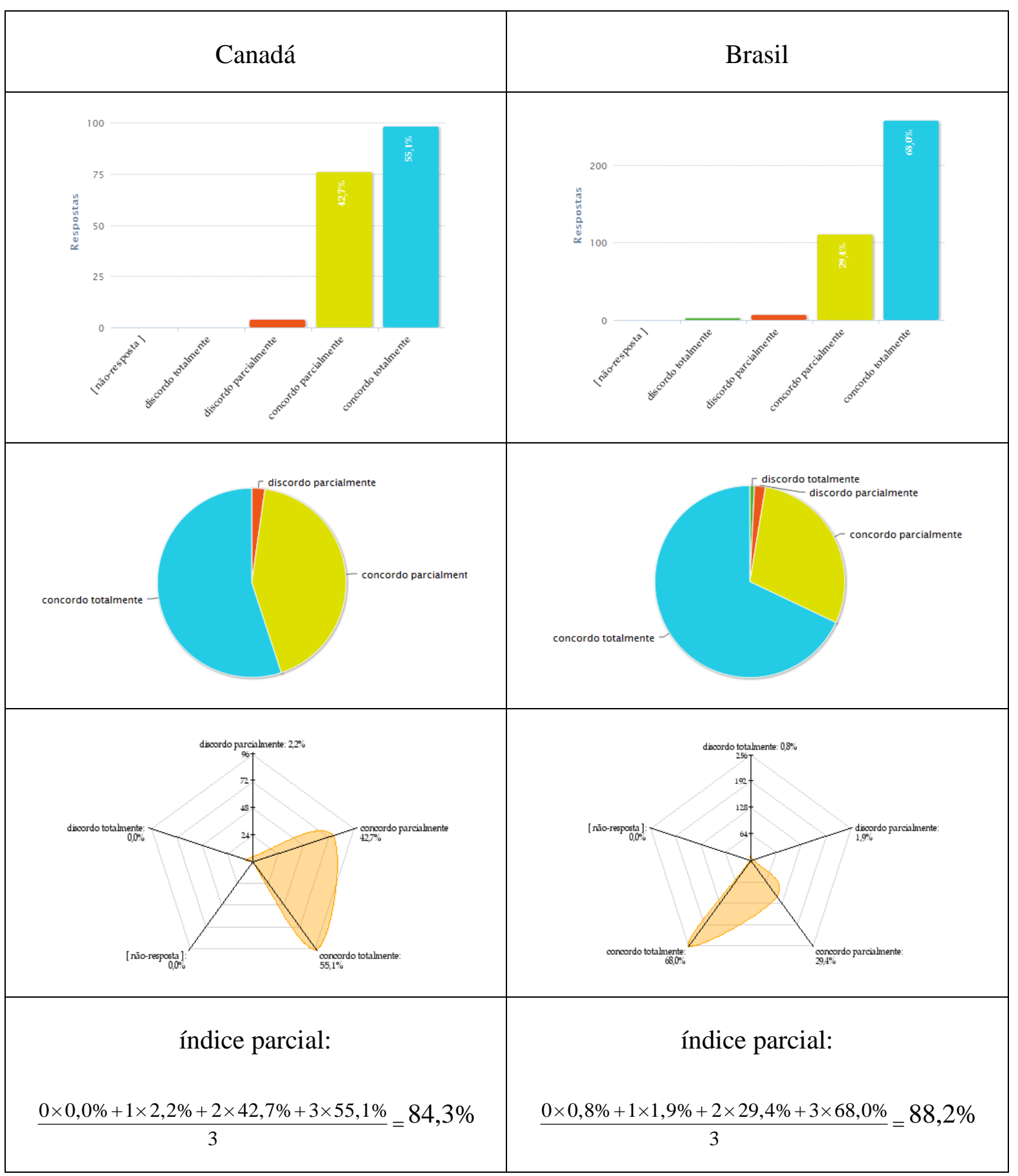

Fonte: o autor 
O valor final calculado para o Índice Motivacional para cada país pesquisado é, portanto:

\begin{tabular}{|l|c|c|}
\cline { 2 - 3 } \multicolumn{1}{c|}{} & Canadá & Brasil \\
\hline Índice de Motivacional: & $\frac{73,5 \%+84,3 \%}{2}=\mathbf{7 8 , 9 \%}$ & $\frac{58,8 \%+88,2 \%}{2}=\mathbf{7 3 , 5} \%$ \\
\hline
\end{tabular}

Os resultados obtidos para o índice sugerem que os respondentes canadenses estão mais motivados profissionalmente que os seus colegas brasileiros, com uma vantagem de $5,4 \%$. 


\subsection{9. Índice Vocacional}

A lógica por detrás do índice vocacional é a de que um profissional que trabalha com o que gosta está utilizando seu capital intelectual de forma plena em seu ambiente de trabalho. Como a maioria dos índices do presente trabalho, o índice vocacional é calculado a partir de duas assertivas do questionário online, que possuem ambas quatro respostas fechadas possíveis.

Primeira assertiva do índice: "Sempre desejei trabalhar na área em que atuo atualmente".

As respostas possíveis para as assertivas do índice vocacional e suas intensidades correspondentes são:

- Intensidade zero:

- Discordo totalmente

- Intensidade 1:

- Discordo parcialmente

- Intensidade 2:

- Concordo parcialmente

- Intensidade 3:

- Concordo totalmente 
A soma das respostas concordantes parcial e totalmente foram de 75,8\% para os respondentes canadenses de $86,6 \%$ para os brasileiros. Os gráficos obtidos através dos dados coletados na pesquisa de campo são:

Tabela 22 - Índice Vocacional- primeira assertiva

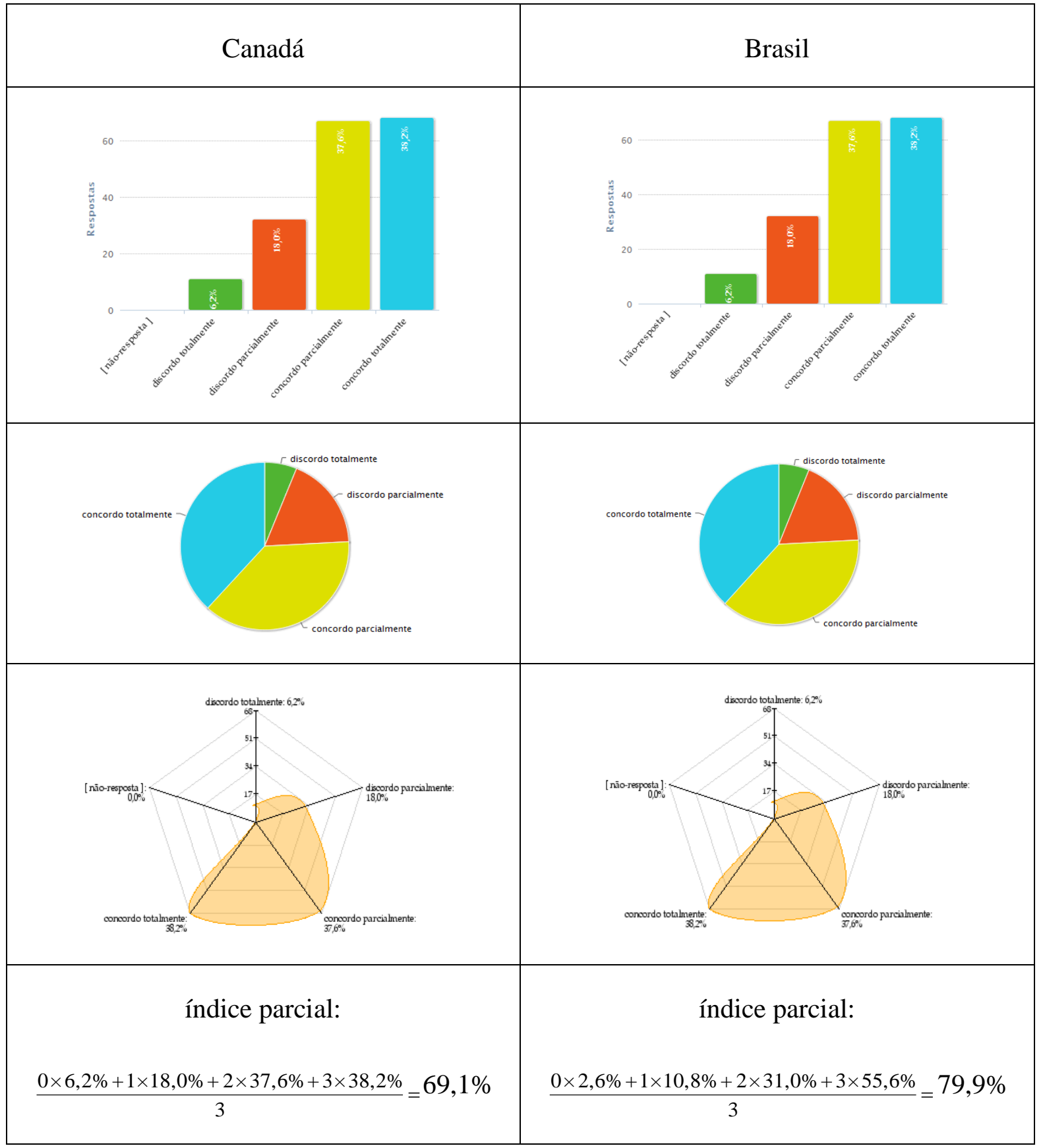

Fonte: o autor 
Segunda assertiva do índice: "Costumo desenvolver softwares desvinculado do trabalho".

As respostas possíveis e suas intensidades correspondentes são:

- Intensidade zero:

- Discordo totalmente

- Intensidade 1:

○ Discordo parcialmente

- Intensidade 2:

○ Concordo parcialmente

- Intensidade 3:

○ Concordo totalmente

A concordância parcial ou total em relação a segunda assertiva 37,1\% para os canadenses, portanto abaixo de 50\%, enquanto que para os respondentes brasileiros foi de 50,8\%, mostrando um quase empate entre concordantes e discordantes. Abaixo estão os dados coletados: 
Tabela 23 - Índice Vocacional - segunda assertiva

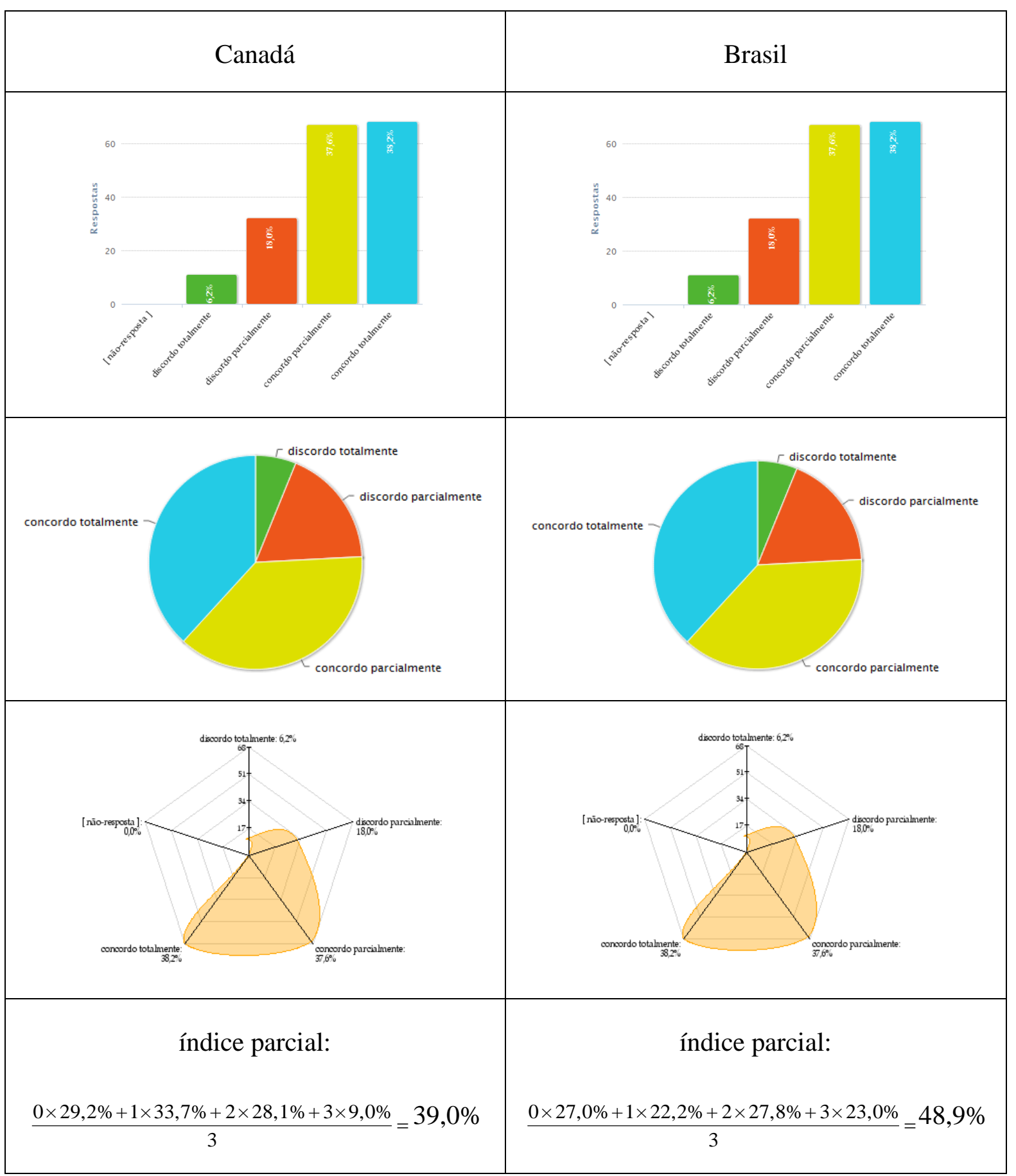

Fonte: o autor 
O valor final calculado para o Índice Vocacional para cada país da pesquisa é, portanto:

\begin{tabular}{|l|c|c|}
\cline { 2 - 3 } \multicolumn{1}{c|}{} & Canadá & Brasil \\
\hline Índice Vocacional: & $\frac{69,1 \%+39,0 \%}{2}=\mathbf{5 4 , 6 \%}$ & $\frac{79,9 \%+48,9 \%}{2}=\mathbf{6 4 , 4 \%}$ \\
\hline
\end{tabular}

Os resultados obtidos para o índice sugerem que os respondentes do Brasil têm maior vocação para a função em que estão trabalhando, isto é, no desenvolvimento de softwares, com uma vantagem de $9,8 \%$ sobre os canadenses. 


\subsection{0. Índice de Coleguismo}

Segundo Stewart, ter uma boa interação com os colegas de trabalho é um fundamental da gestão excelente do capital intelectual dos trabalhadores, e é portanto o que fundamenta o índice de coleguismo do presente trabalho. Como a maioria dos índices do presente trabalho, o índice de coleguismo é calculado a partir de duas assertivas do questionário online, que possuem ambas quatro respostas fechadas possíveis.

Primeira assertiva do índice: "Sempre desejei trabalhar na área em que atuo atualmente".

As respostas possíveis para as assertivas do índice vocacional e suas intensidades correspondentes são:

- Intensidade zero:

- Discordo totalmente

- Intensidade 1:

- Discordo parcialmente

- Intensidade 2:

- Concordo parcialmente

- Intensidade 3:

- Concordo totalmente 
A soma das respostas concordantes parcial e totalmente foram muito altas para ambos os países, com 95,0\% para os respondentes canadenses e 93,5\% para os brasileiros. Os gráficos obtidos através dos dados coletados na pesquisa de campo são:

Tabela 24 - Índice de Coleguismo- primeira assertiva

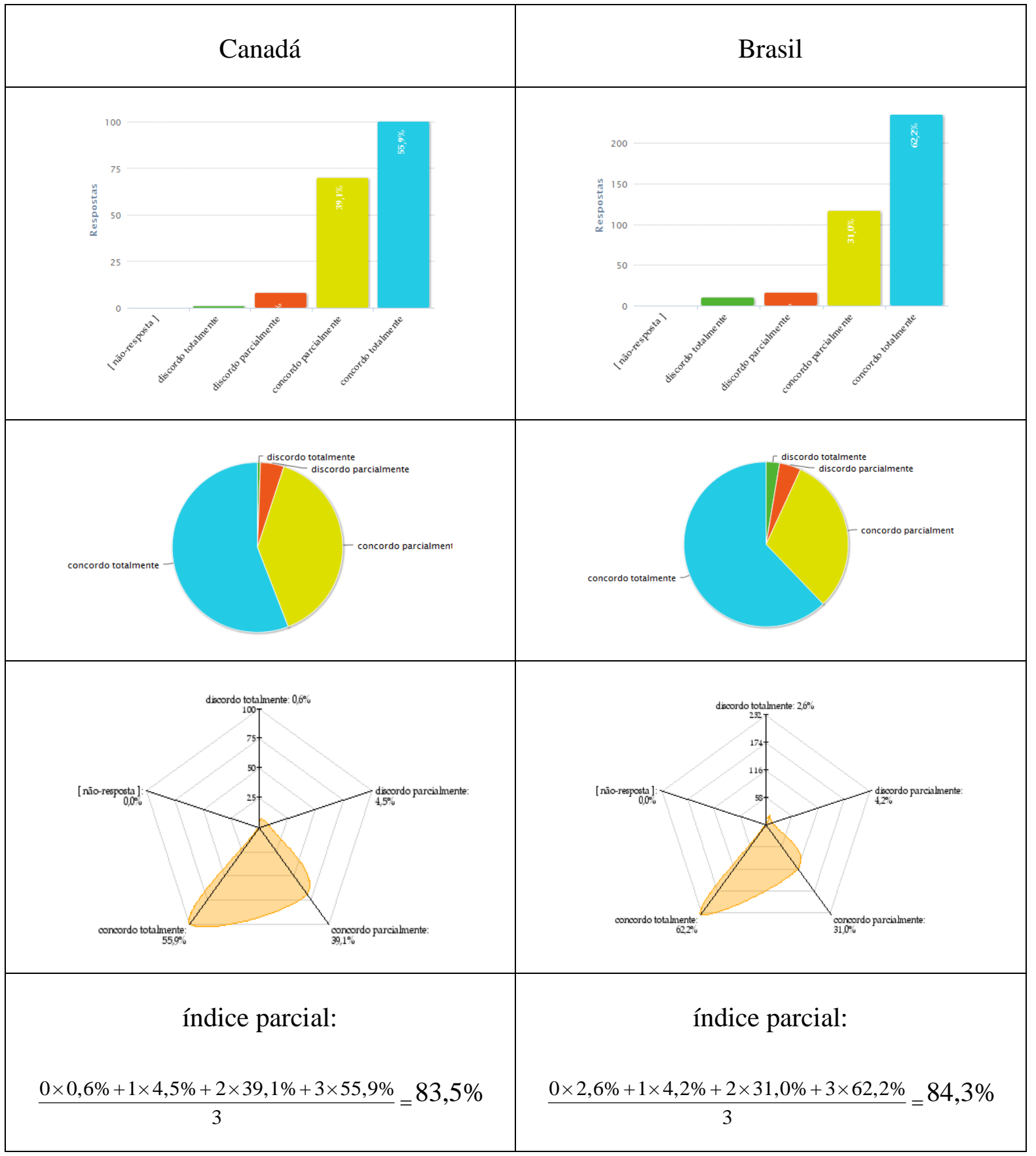

Fonte: o autor 
Segunda assertiva do índice: "Participo com muita freqüência de confraternizações com meus colegas de trabalho".

As respostas possíveis e suas intensidades correspondentes são:

- Intensidade zero:

- Discordo totalmente

- Intensidade 1:

- Discordo parcialmente

- Intensidade 2:

- Concordo parcialmente

- Intensidade 3:

○ Concordo totalmente

A concordância parcial ou total em relação à segunda assertiva 60,4\% para os canadenses, enquanto que para os respondentes brasileiros foi de $76,2 \%$. Abaixo estão os dados coletados: 
Tabela 25 - Índice de Coleguismo - segunda assertiva

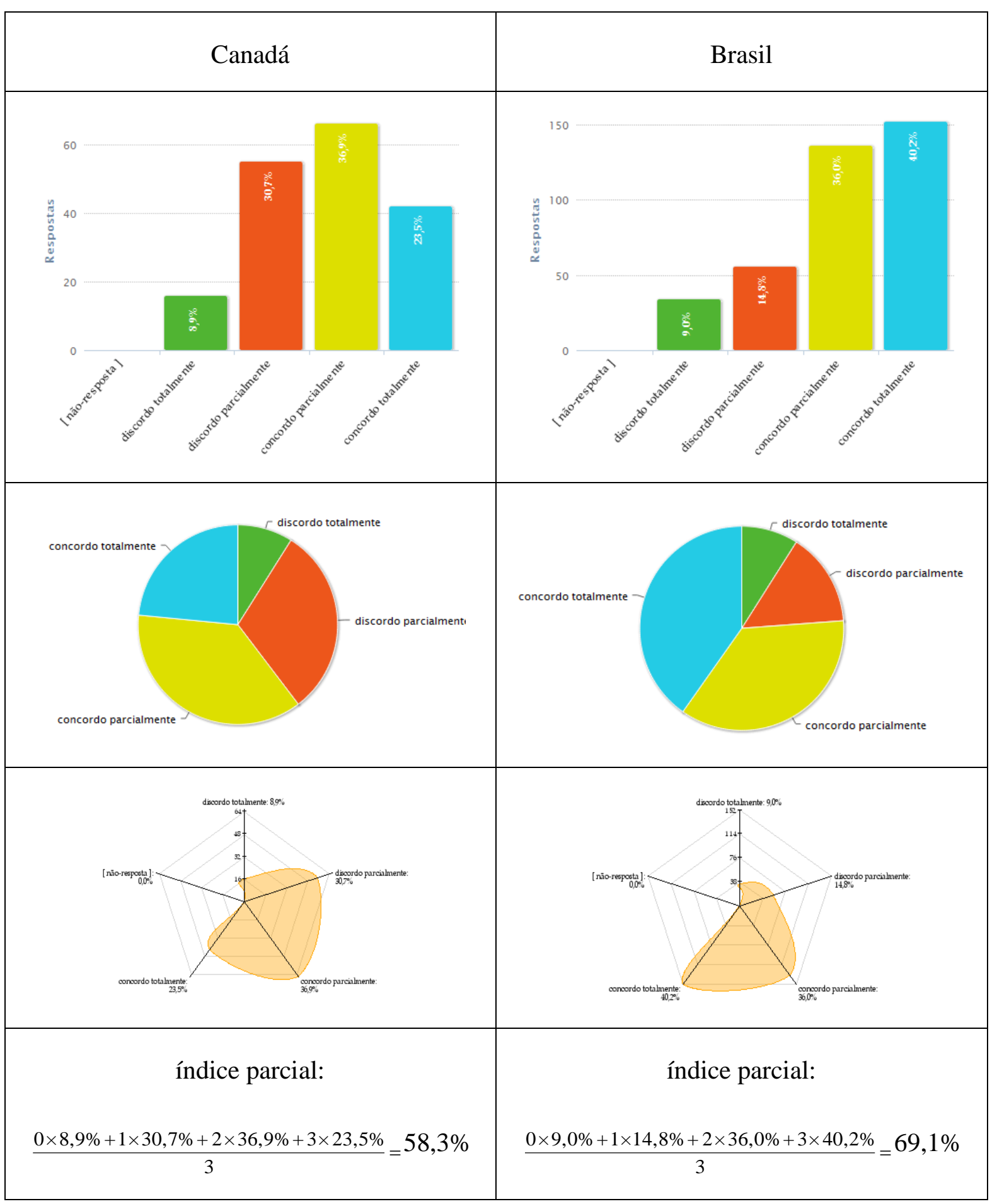

Fonte: o autor 
O valor final calculado para o Índice de Coleguismo para cada país da pesquisa é, portanto:

\begin{tabular}{|c|c|c|}
\hline & Canadá & Brasil \\
\hline Índice de Coleguismo: & $\frac{83,5 \%+58,3 \%}{2}=\mathbf{7 0 , 9 \%}$ & $\frac{84,3 \%+69,1 \%}{2}=\mathbf{7 6 , 7 \%}$ \\
\hline
\end{tabular}

Os resultados obtidos para o índice de coleguismo mostram, assim, que os respondentes brasileiros tiveram um resultado 5,8\% maior que o resultados dos canadenses com relação ao bom coleguismo no ambiente de trabalho. 


\subsection{1. Índice de Poder de Decisão (empowerment)}

Os autores Edvinsson \& Malone, Brooking e Stewart argumentam em seus trabalhos sobre capital intelectual sobre a importância do poder de decisão dos profissionais em seus ambientes de trabalho, chamado em inglês de empowerment. Sendo assim, de acordo com o quadro 6.3, o presente trabalho procura medir o índice de poder de decisão. Como a maioria dos índices propostos, ele é calculado a partir de duas assertivas do questionário online, que possuem ambas quatro respostas fechadas possíveis.

Primeira assertiva do índice: "Tenho amplo controle sobre as minhas funções no trabalho".

As respostas possíveis para as assertivas do índice vocacional e suas intensidades correspondentes são:

- Intensidade zero:

- Discordo totalmente

- Intensidade 1:

- Discordo parcialmente

- Intensidade 2:

- Concordo parcialmente

- Intensidade 3:

- Concordo totalmente 
A soma das respostas concordantes parcial e totalmente foram próximas entre os países, com $88,8 \%$ para os respondentes canadenses e $87,8 \%$ para os brasileiros. Os gráficos obtidos através dos dados coletados na pesquisa de campo são:

Tabela 26 - Índice de Poder de Decisão - primeira assertiva

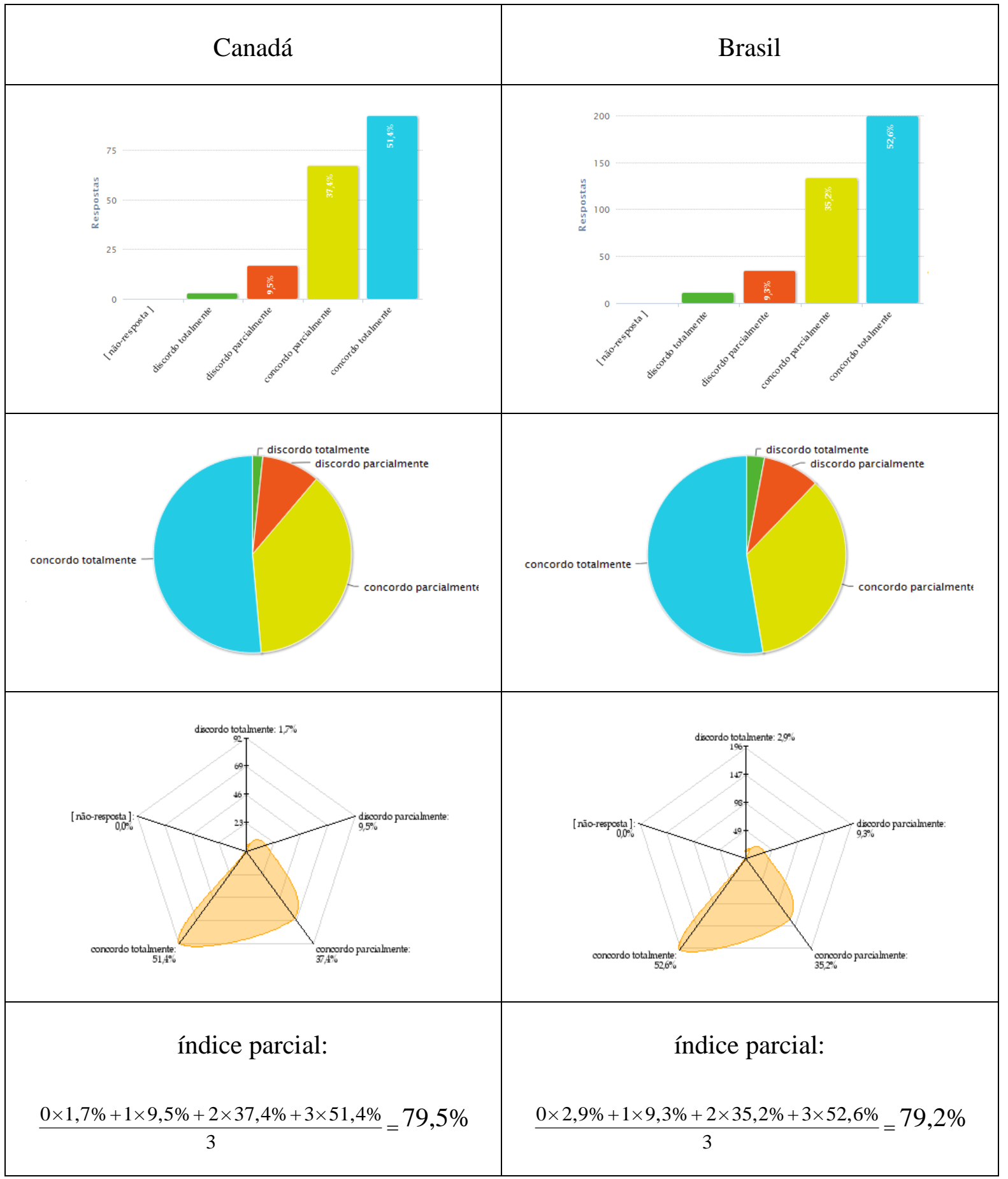

Fonte: o autor 
Segunda assertiva do índice: "Participo com muita freqüência de confraternizações com meus colegas de trabalho".

As respostas possíveis e suas intensidades correspondentes são:

- Intensidade zero:

- Discordo totalmente

- Intensidade 1:

- Discordo parcialmente

- Intensidade 2:

○ Concordo parcialmente

- Intensidade 3:

○ Concordo totalmente

A concordância parcial ou total em relação à segunda assertiva 86,6\% para os canadenses, enquanto que para os respondentes brasileiros foi de 75,4\%. Abaixo estão os dados coletados: 
Tabela 27 - Índice de Poder de Decisão - segunda assertiva

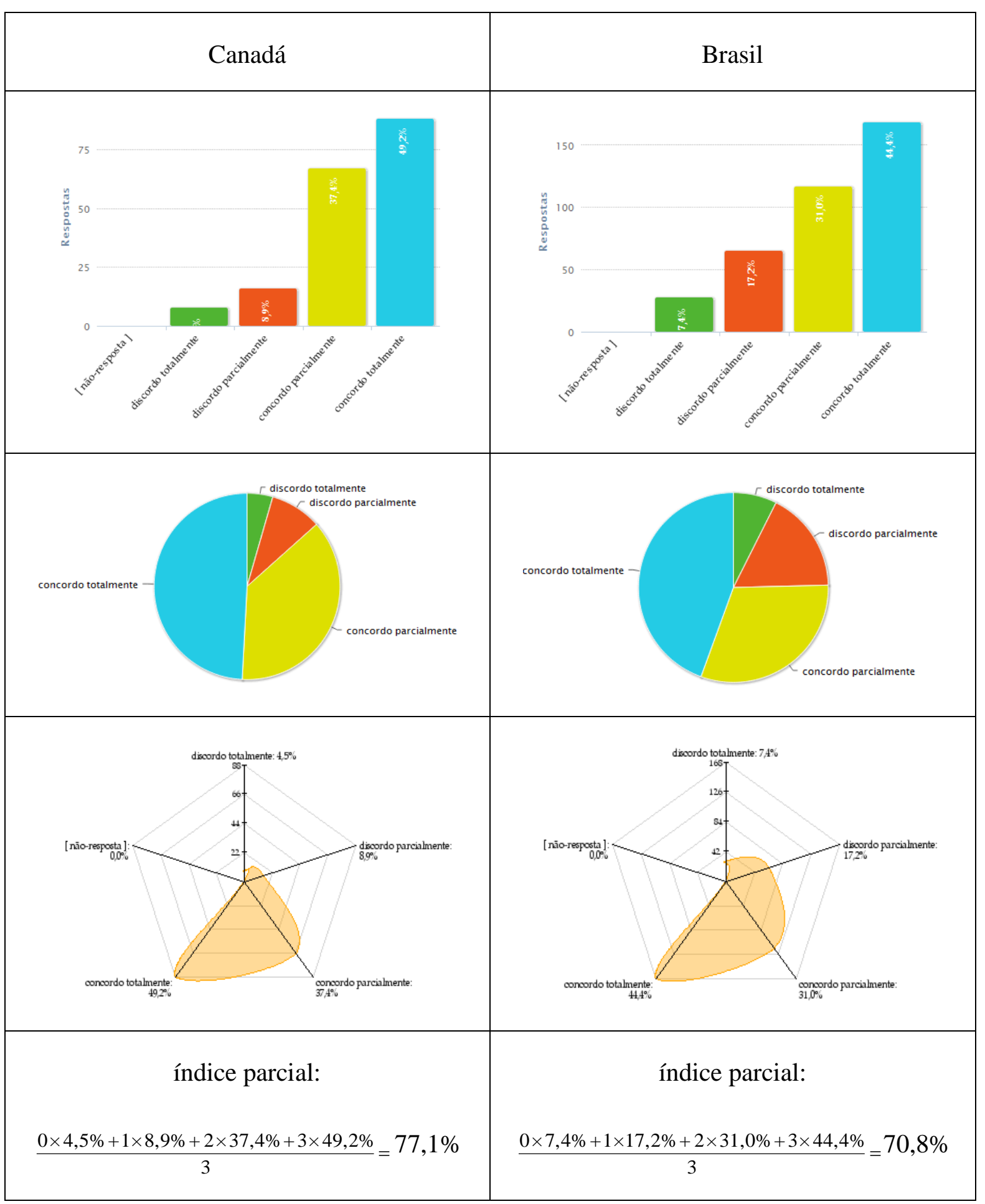

Fonte: o autor 
Assim, de acordo com método de cálculo proposto, o valor final do Índice de Poder de Decisão para cada país da pesquisa é:

\begin{tabular}{|l|c|c|}
\cline { 2 - 3 } \multicolumn{1}{c|}{} & Canadá & Brasil \\
\hline Índice de Poder de Decisão: & $\frac{79,5 \%+77,1 \%}{2}=\mathbf{7 8 , 3} \%$ & $\frac{79,2 \%+70,8 \%}{2}=\mathbf{7 5 , 0} \%$ \\
\hline
\end{tabular}

Os resultados obtidos para o índice de poder de decisão mostram, assim, que os respondentes do Canadá tiveram um resultado 3,3\% maior que o resultado dos brasileiros em relação ao poder de decisão em seus ambientes de trabalho. 


\subsection{2. Índice de Contato Direto com Clientes}

A teoria sobre capital intelectual consultada e analisada levou à conclusão de que o contato direto dos desenvolvedores de software com os clientes que usam o produto final de seu trabalho é um fator fundamental para a gestão excelente do capital intelectual. Também como a maioria dos índices do presente trabalho, o índice de contato direto com clientes é calculado a partir de duas assertivas do questionário online, que possuem ambas quatro respostas fechadas possíveis.

Primeira assertiva do índice: "Comunico-me constantemente com os clientes dos projetos que participo".

As respostas possíveis para as assertivas do índice vocacional e suas intensidades correspondentes são:

- Intensidade zero:

- Discordo totalmente

- Intensidade 1:

- Discordo parcialmente

- Intensidade 2:

- Concordo parcialmente

- Intensidade 3:

- Concordo totalmente 
A soma das respostas concordantes parcial e totalmente foram maioria para ambos os países, com 86,0\% para os respondentes canadenses e 80,2\% para os brasileiros. Os gráficos obtidos através dos dados coletados na pesquisa de campo são:

Tabela 28 - Índice de Contato Direto com Clientes- primeira assertiva

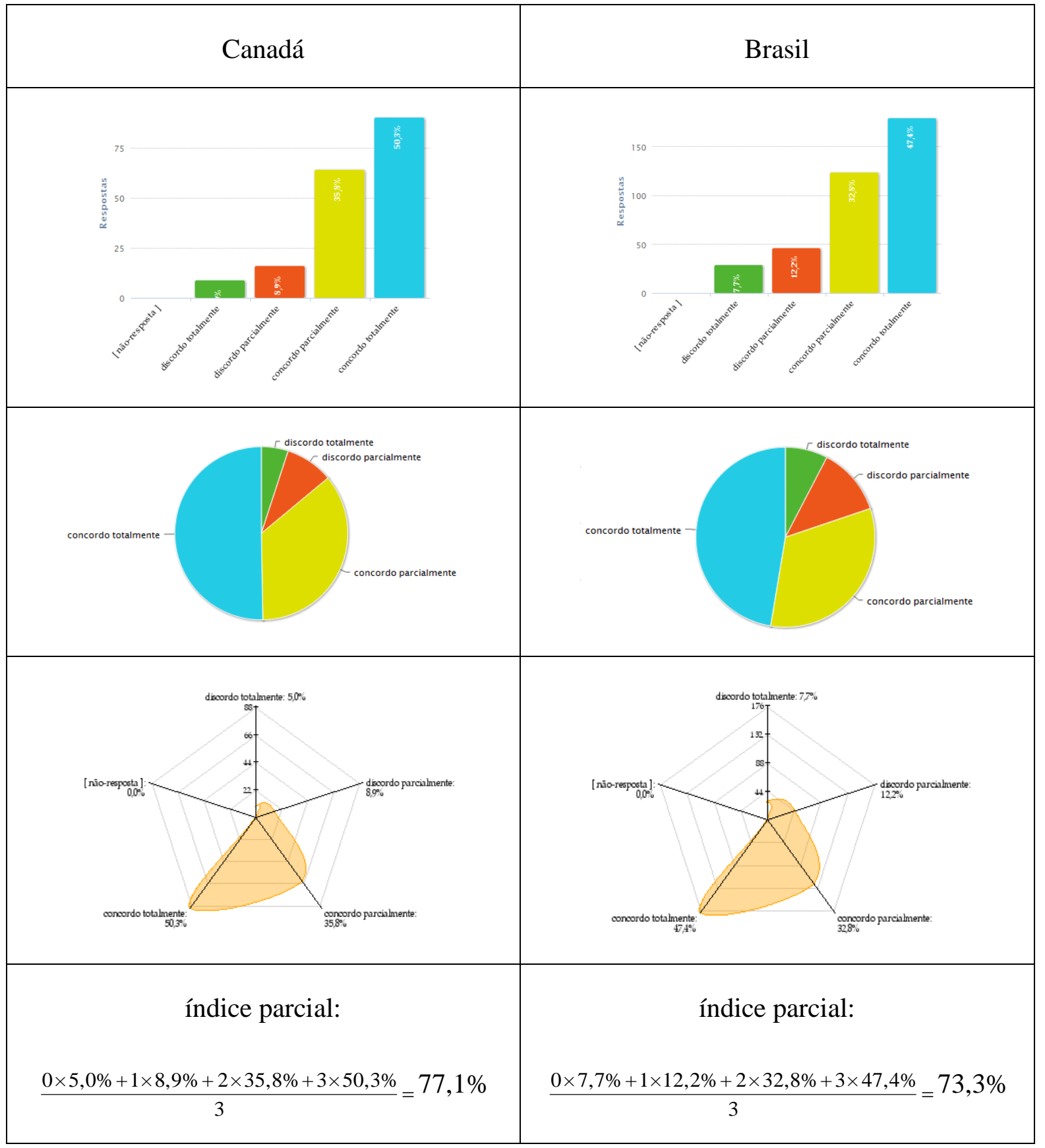

Fonte: o autor 
Segunda assertiva do índice: "Visito rotineiramente os clientes dos projetos nos quais participo".

As respostas possíveis e suas intensidades correspondentes são:

- Intensidade zero:

- Discordo totalmente

- Intensidade 1:

- Discordo parcialmente

- Intensidade 2:

○ Concordo parcialmente

- Intensidade 3:

○ Concordo totalmente

A concordância parcial ou total em relação a segunda assertiva foi $67,0 \%$ para os canadenses, enquanto que para os respondentes brasileiros foi de $64,5 \%$. Abaixo estão os gráficos gerados a partir dos dados coletados: 
Tabela 29 - Índice de Contato Direto com Clientes - segunda assertiva

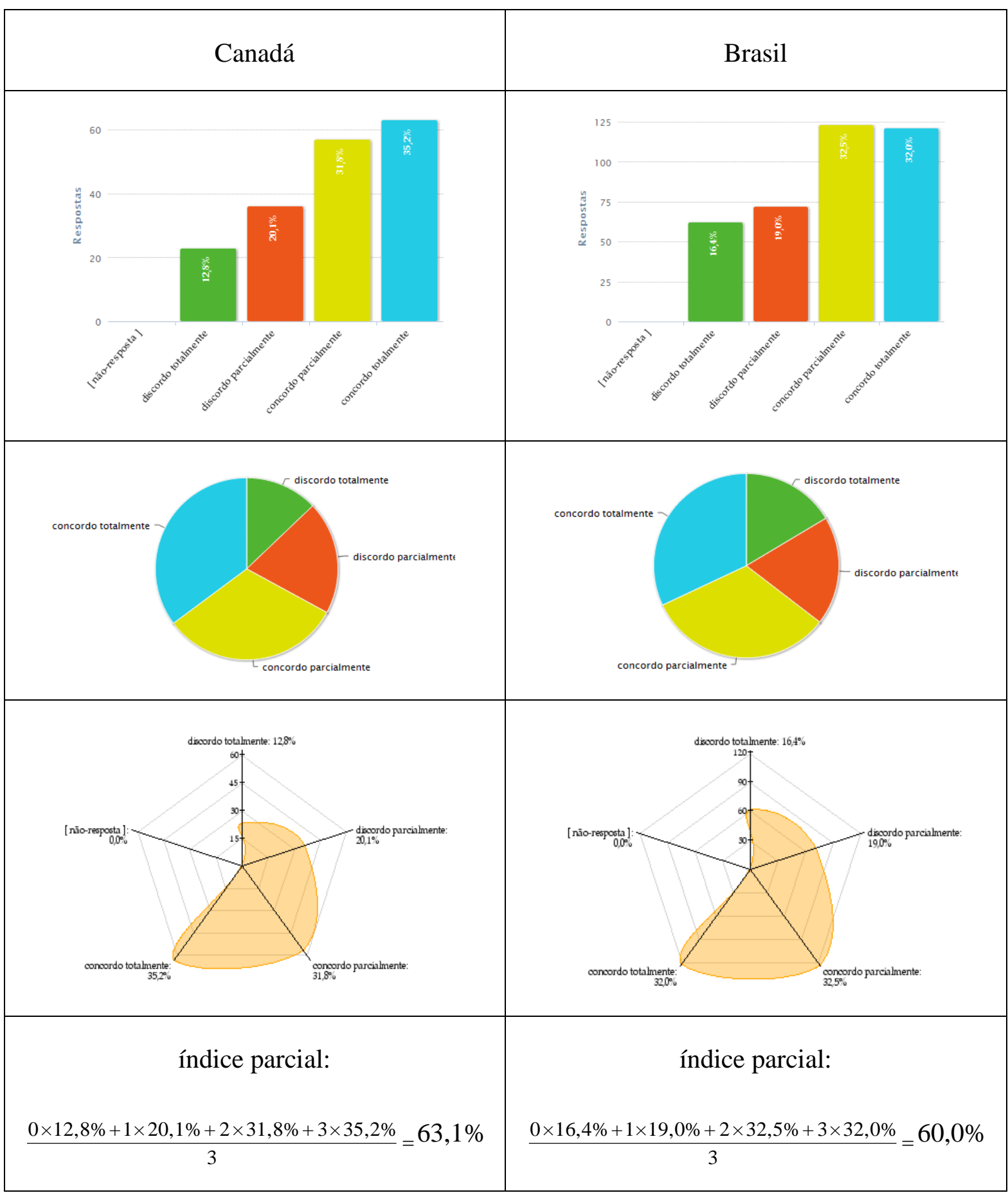

Fonte: o autor 
Por conseguinte, o valor final calculado para o Índice de Contato Direto com Clientes para cada país da pesquisa é:

\begin{tabular}{|c|c|c|}
\hline & Canadá & Brasil \\
\hline $\begin{array}{l}\text { Índice de Contato Direto com } \\
\text { Clientes: }\end{array}$ & $\frac{77,1 \%+63,1 \%}{2}=\mathbf{7 0 , 1 \%}$ & $\frac{73,3 \%+60,0 \%}{2}=66,7 \%$ \\
\hline
\end{tabular}

Os resultados obtidos para o índice de contato direto com clientes indica, portanto, uma pequena vantagem de $3,4 \%$ para os respondentes do Canadá em relação aos respondentes brasileiros. 


\subsection{3. Índice de Rotatividade}

O índice de rotatividade, baseado na teoria de Edvinsson \& Malone, conforme o quadro 6.3, é calculado a partir das respostas de duas questões do questionário que, ao contrário da maioria, possuem mais de 4 opções de respostas. Como forma de equipar o índice aos demais, foi feito um ajuste arbitrário das respostas, agrupando-as em quatro conjuntos com intensidades de zero a três, equiparando-se assim à maioria das questões da pesquisa.

Primeira questão do índice de rotatividade: “Quantos empregos você já teve como programador/analista de sistemas, contando com o atual?".

Seguindo-se a lógica de que quanto menos o respondente trocou de emprego maior o índice, o agrupamento das 5 opções de resposta possíveis foi o seguinte:

- Intensidade zero:

○ Cinco ou mais empregos

○ Quatro empregos

- Intensidade 1:

○ Três empregos

○ Três empregos

- Intensidade 2:

○ Dois empregos

- Intensidade 3:

○ Um emprego

Numa primeira análise na comparação Canadá x Brasil, é notável a diferença entre aqueles que só tiveram um único emprego até o momento, com 16,7\% para os canadenses 
contra $36,7 \%$ para os brasileiros, o que permite supor que tal resultado esteja diretamente ligado à maior juventude dos respondentes do Brasil, conforme visto acima na análise das variáveis de perfil. Vejamos os dados coletados: 
Tabela 30 - Índice de Rotatividade - primeira questão

\begin{tabular}{|c|c|}
\hline Canadá & Brasil \\
\hline ن & Cinco ou mais ? \\
\hline $\begin{array}{l}\text { índice parcial: } \\
\frac{0 \times 33,3 \%+1 \times 24,4 \%+2 \times 25,6 \%+3 \times 16,7 \%}{3}=41,9 \%\end{array}$ & $\begin{array}{l}\text { índice parcial: } \\
\frac{0 \times 16,1 \%+1 \times 19,5 \%+2 \times 27,7 \%+3 \times 36,7 \%}{3}=70,9 \%\end{array}$ \\
\hline
\end{tabular}

Fonte: o autor

Nota-se, dessa maneira, uma grande vantagem de $29,0 \%$ para os respondentes brasileiros em relação à rotatividade, desempenho esse que pode ser parcialmente explicado pela 
considerável diferença nos perfis etários de ambos os países, conforme os dados expostos na tabela 3.

Segunda questão do índice: "Há quanto tempo você trabalha profissionalmente como programador/analista de sistemas?".

A lógica de agrupamento e a associação de intensidades para a segunda questão procuram exatamente uma compensação algébrica para o índice de rotatividade, já que há uma tendência natural de aumento do número de empregos conforme o tempo de vida profissional aumente. Sendo assim, exemplificando, para um respondente ter individualmente um índice de $100 \%$, ele deve ter respondido que teve apenas um emprego até o momento (primeira questão), e também ter respondido ter 10 ou mais anos de experiência profissional como desenvolvedor de software (segunda questão).

O agrupamento das 7 opções de resposta possíveis foi o seguinte:

- Intensidade zero:

○ Menos de 1 ano de experiência

- Entre 1 e 2 anos de experiência

- Intensidade 1:

- Entre 2 e 3 anos de experiência

- Entre 3 e 4 anos de experiência

- Intensidade 2:

- Entre 4 e 5 anos de experiência

- Entre 5 e 10 anos de experiência

- Intensidade 3:

- Mais de 10 anos de experiência 
As respostas à segunda questão do índice de rotatividade refletem a diferença de idade entre os respondentes dos dois países, conforme visto na tabela 3. Seguem os gráficos obtidos dos dados coletados:

Tabela 31 - Índice de Rotatividade - segunda questão

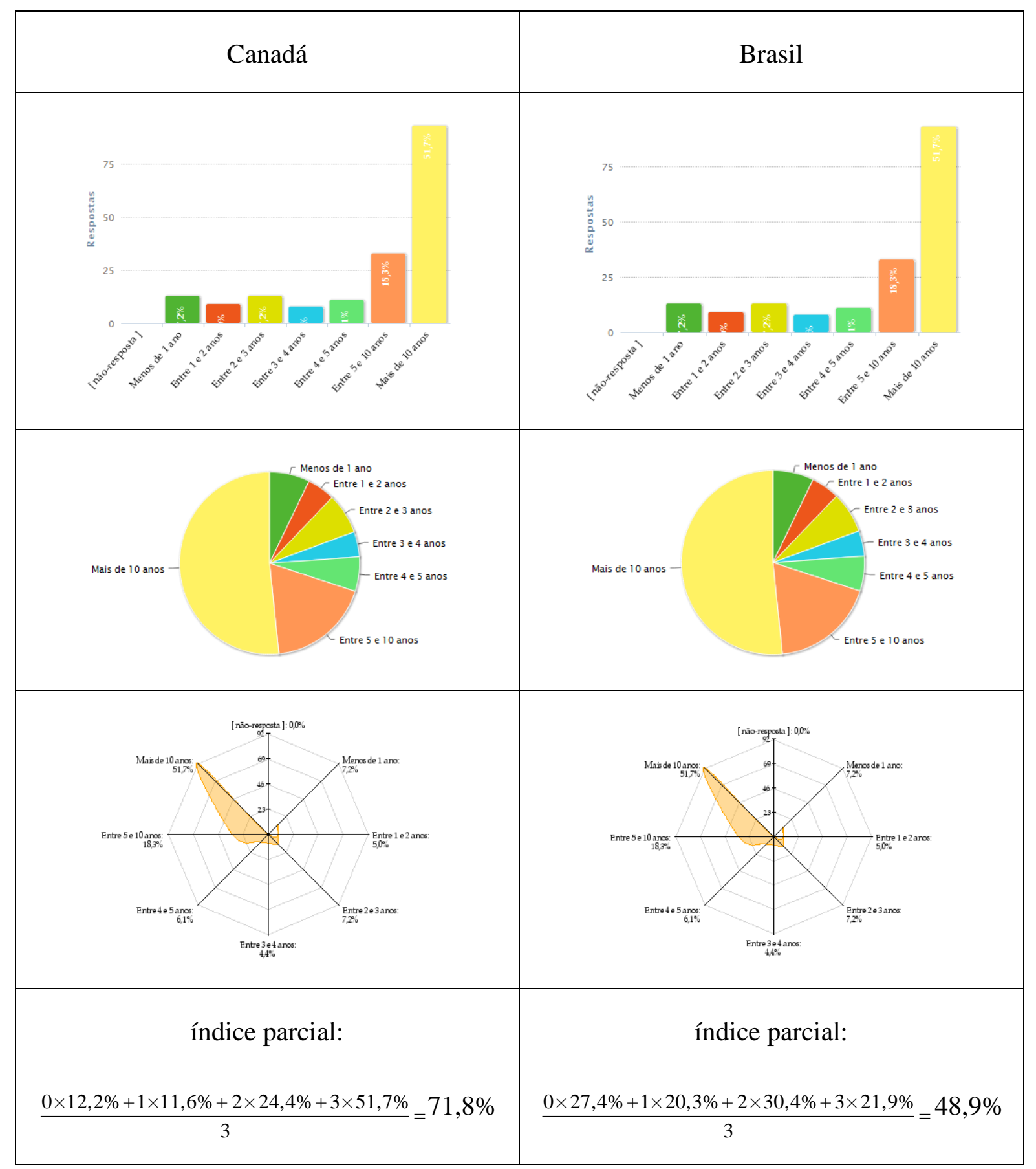

Fonte: o autor 
Temos, portanto, o seguinte resultado para o Índice de Rotatividade:

\begin{tabular}{|l|c|c|}
\cline { 2 - 3 } \multicolumn{1}{c|}{} & Canadá & Brasil \\
\hline Índice de Rotatividade: & $\frac{41,9 \%+71,8 \%}{2}=\mathbf{5 6 , 9 \%}$ & $\frac{70,9 \%+48,9 \%}{2}=\mathbf{5 9 , 9 \%}$ \\
\hline
\end{tabular}

Nota-se assim um desempenho ligeiramente melhor dos respondentes brasileiros em relação à rotatividade, com resultado 3,0\% superior. 


\subsection{4. Índice Hierárquico}

O índice hierárquico é o resultado da investigação acerca da posição do profissional de TI dentro da hierarquia interna da instituição a que pertence, e também procura determinar qual é o nível básico das competências técnicas específicas de um desenvolvedor de softwares, que é a profissão chave do presente trabalho. Também ao contrário da maioria, as questões do índice hierárquico possuem mais de 4 opções de respostas. Como forma de equipar o índice aos demais, foi feito um ajuste arbitrário das respostas, agrupando-as em quatro conjuntos com intensidades de zero a três, equiparando-se assim à maioria das questões da pesquisa.

Primeira questão do índice de rotatividade: "Quantas vezes você já foi promovido, trabalhando como programador/analista de sistemas?".

Segue-se a lógica de que quanto mais vezes o respondente foi promovido, maior o índice. O agrupamento das 5 respostas possíveis foi o seguinte:

- Intensidade zero:

○ Nenhuma vez

- Intensidade 1:

- Uma vez

○ Duas vezes

- Intensidade 2:

○ Três vezes

- Intensidade 3:

○ Quatro ou mais vezes 
Numa primeira análise na comparação entre os países, é notável o melhor desempenho do Canadá com relação a essa primeira questão do índice hierárquico, com $25 \%$ dos canadenses contra $11,8 \%$ dos brasileiros que declararam terem sido quatro ou mais vezes promovidos, além de que enquanto somente $19,4 \%$ dos canadenses participantes da pesquisa nunca terem sido promovidos, uma proporção de $36,1 \%$ dos brasileiros também nunca foram promovidos. Pode-se assim, novamente, supor que tal resultado esteja diretamente ligado à maior juventude dos respondentes do Brasil, conforme já comentado. Seguem os dados coletados: 
Tabela 32 - Índice Hierárquico- primeira questão

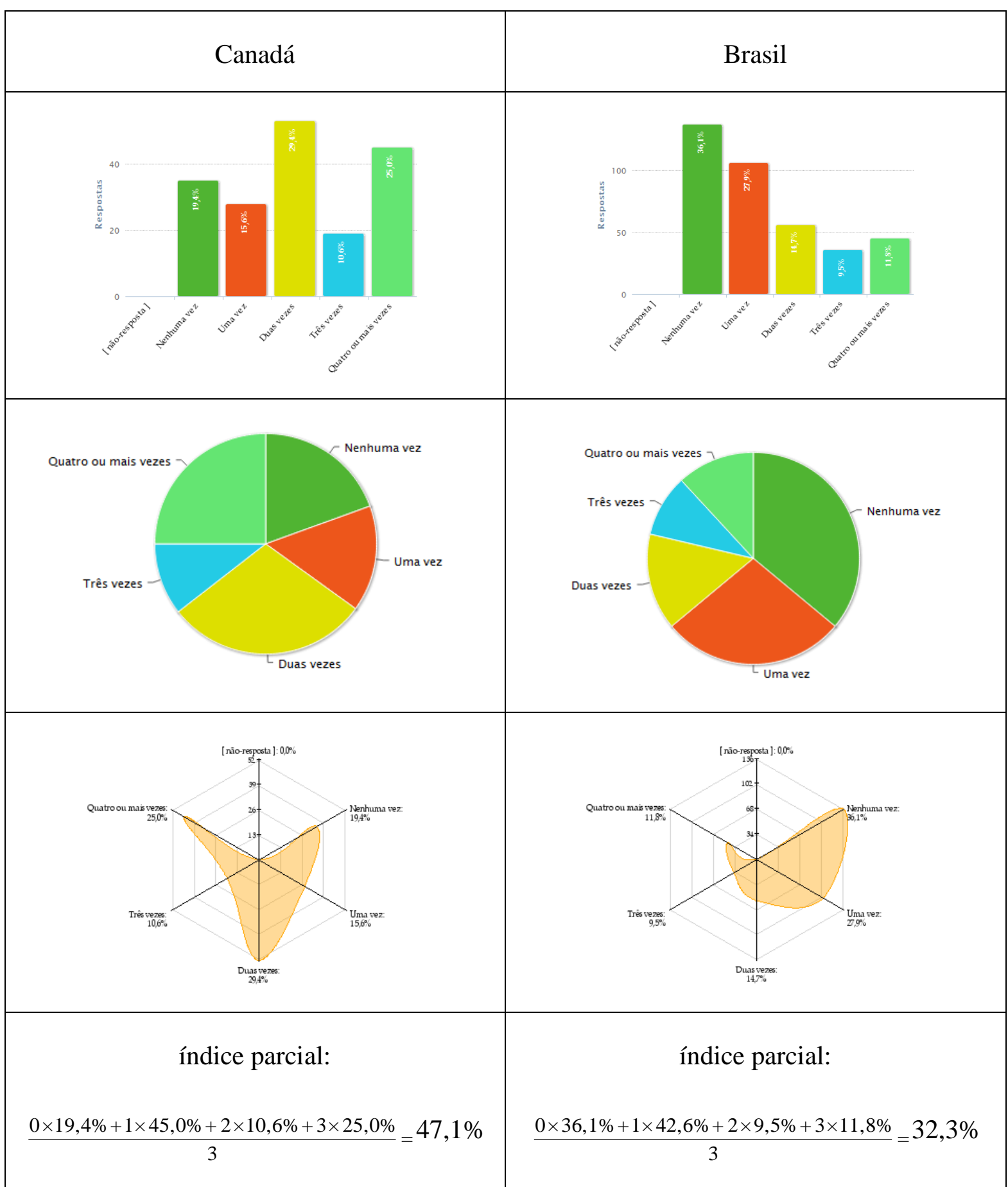

Fonte: o autor

Segunda questão do índice: "Há quanto tempo você trabalha profissionalmente como programador/analista de sistemas?". 
Essa questão foi a única do questionário de pesquisa, excluindo-se as de perfil, que possui apenas 3 opções de resposta. Sendo assim, como forma de evitar distorções algébricas, optouse por atribuir a intensidade 1,5 para a resposta "intermediário" no cálculo do índice parcial, inexistindo portanto a intensidade 2 , como em todas as demais questões.

O agrupamento das 3 opções de resposta possíveis foi o seguinte:

- Intensidade zero:

○ Nível iniciante

- Intensidade 1,5:

○ Nível Intermediário

- Intensidade 3:

○ Nível avançado

As respostas à segunda questão do índice hierárquico também parecem refletir a diferença de idade entre os respondentes dos dois países. Seguem os gráficos obtidos dos dados coletados: 
Tabela 33 - Índice Hierárquico- segunda questão

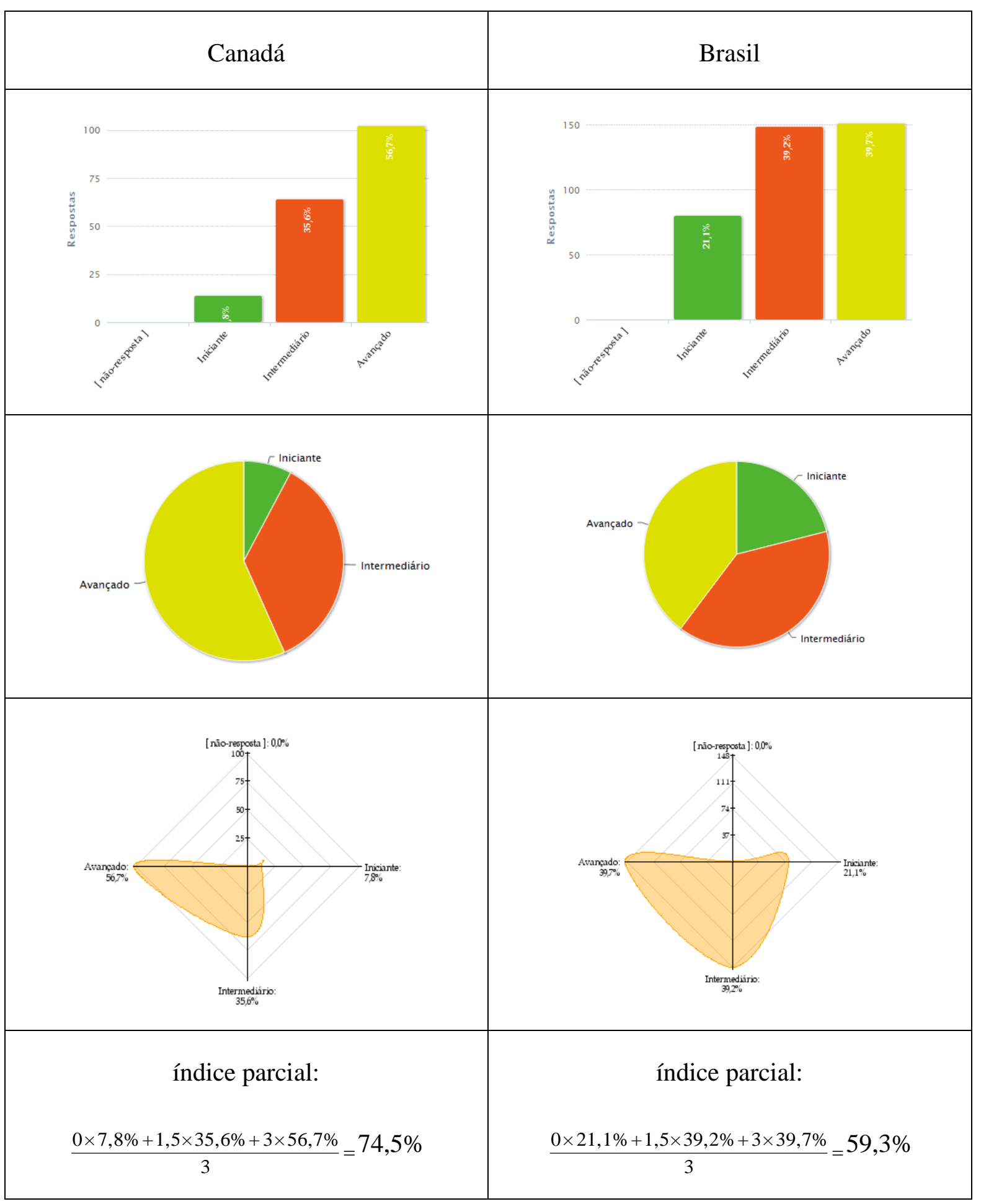

Fonte: o autor 
Temos, portanto, o seguinte resultado para o Índice Hierárquico:

\begin{tabular}{|c|c|c|}
\hline & Canadá & Brasil \\
\hline Índice Hierárquico: & $\frac{47,1 \%+74,5 \%}{2}=\mathbf{6 0 , 8} \%$ & $\frac{32,3 \%+59,3 \%}{2}=\mathbf{4 5 , 8 \%}$ \\
\hline
\end{tabular}

Houve portanto um desempenho $15,0 \%$ maior para os respondentes canadenses em relação aos brasileiros para o Índice Hierárquico. 


\subsection{5. Índice do Papel Contábil}

O índice do papel contábil do desenvolvedor de softwares procura medir o quanto a instituição que o emprega considera o seu capital intelectual como algo que aumenta o seu balanço patrimonial, considerando o profissional como um passivo da empresa, que precisa ser valorizado, e não como um custo que no futuro possa ser até mesmo eliminado. Do total de 13 índices, o índice do papel contábil faz parte dos 4 índices que, possuem mais de 4 opções de respostas possíveis. Como forma de equipar o índice aos demais, foi feito um ajuste arbitrário das respostas, agrupando-as em quatro conjuntos com intensidades de zero a três, equiparando-se assim à maioria das questões da pesquisa.

Primeira questão do índice do papel contábil: “Qual é o tipo de seu vínculo contratual de trabalho?".

A lógica de agrupamento é arbitrária e traz uma carga subjetiva principalmente nas intensidades intermediárias, porém minha experiência prática como desenvolvedor de softwares, em empresas brasileiras de diversos portes, leva a crer que é coerente considerar como intensidade zero o vínculo "informal” e considerar como intensidade máxima o vínculo formal (de acordo com a CLT - consolidação das leis do trabalho, no caso brasileiro). Houve também um total de $8,9 \%$ de respostas do tipo "outro", às quais será atribuída a intensidade média de 1,5, como forma de neutralizá-las algebricamente. O agrupamento das 7 respostas possíveis foi o seguinte: 
- Intensidade zero:
○ Vínculo informal
○ Autônomo

- Intensidade 1:
- Pessoa Jurídica
○ Cooperado

- Intensidade 1,5:

○ Outro

- Intensidade 2:

\section{○ Estagiário}

- Intensidade 3:

○ Vínculo formal (CLT)

A seguir estão os gráficos obtidos a partir dos dados coletados na pesquisa online: 
Tabela 34 - Índice do Papel Contábil - primeira questão

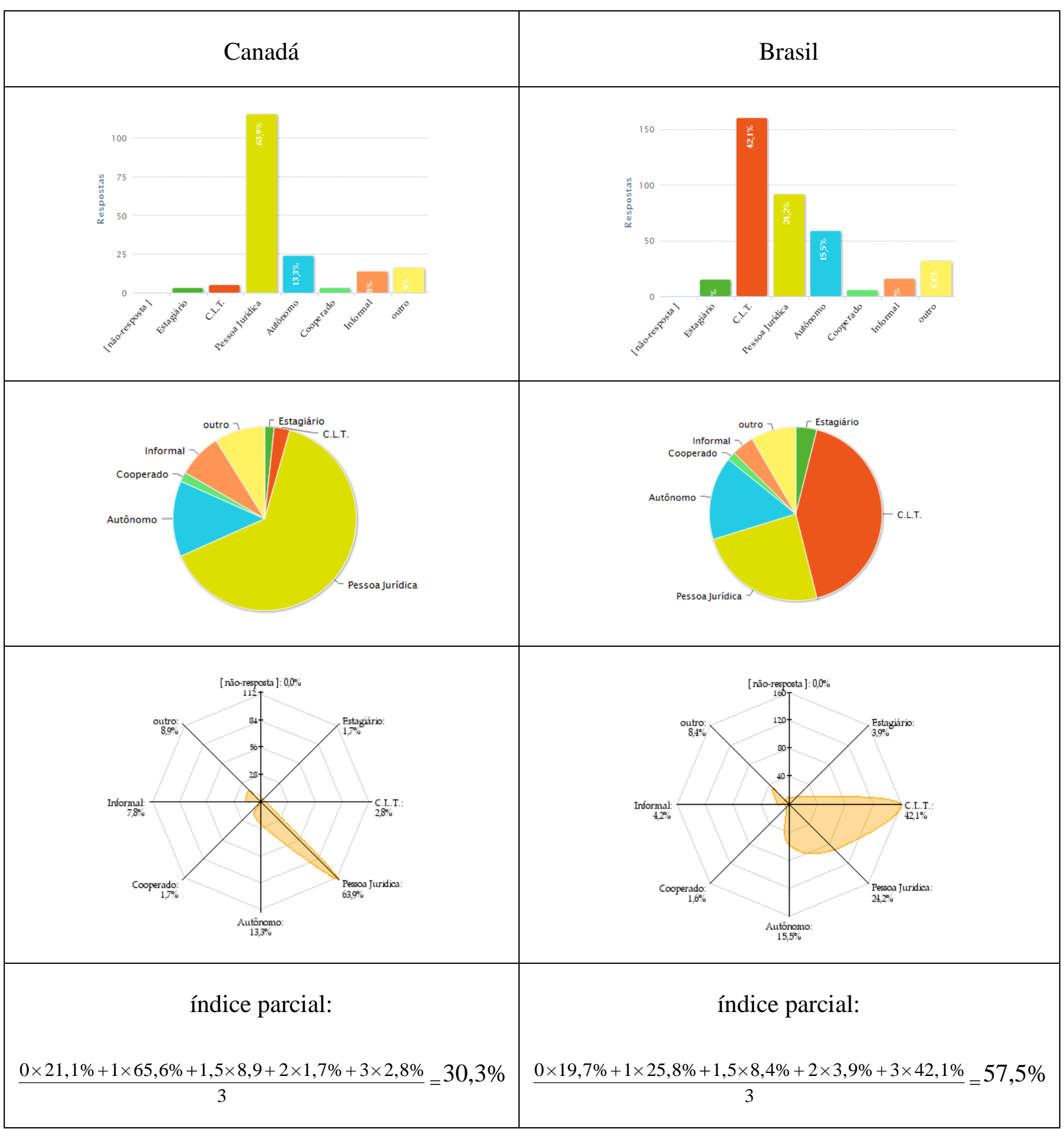

Fonte: o autor 
Temos então um desempenho 27,2\% superior para os respondentes brasileiros, enquanto o índice parcial calculado para os respondentes do Canadá ficou abaixo de 1/3 do máximo possível. É notável a grande diferença entre os países em relação à proporção dos trabalhadores com vínculo formal (CLT), com 42,1\% para os brasileiros contra apenas 2,8\% para os canadenses. Também há forte diferença entre o vínculo de trabalho do tipo "pessoa jurídica”, com $24,2 \%$ dos brasileiros respondentes contra $63,9 \%$ para os canadenses.

Segunda questão do índice: "Qual foi a sua remuneração variável no ano passado? (participação nos lucros, bônus, gratificação, $14^{\circ}$ salário, etc)”.

Essa questão, diferentemente da maioria, tem 5 opções de resposta, e assim foi necessário um agrupamento arbitrário para agrupar as respostas em 4 intensidades. $\mathrm{O}$ agrupamento das 5 opções de resposta foi portanto o seguinte:

- Intensidade zero:

○ Zero (não recebi remuneração variável)

- Intensidade 1:

○ Menos de 1 salário

○ Entre 1 e 2 salários

- Intensidade 2:

○ Entre 2 e 3 salários

- Intensidade 3:

- Mais de 3 salários

A seguir estão os gráficos obtidos a partir dos dados coletados: 
Tabela 35 - Índice do Papel Contábil - segunda questão

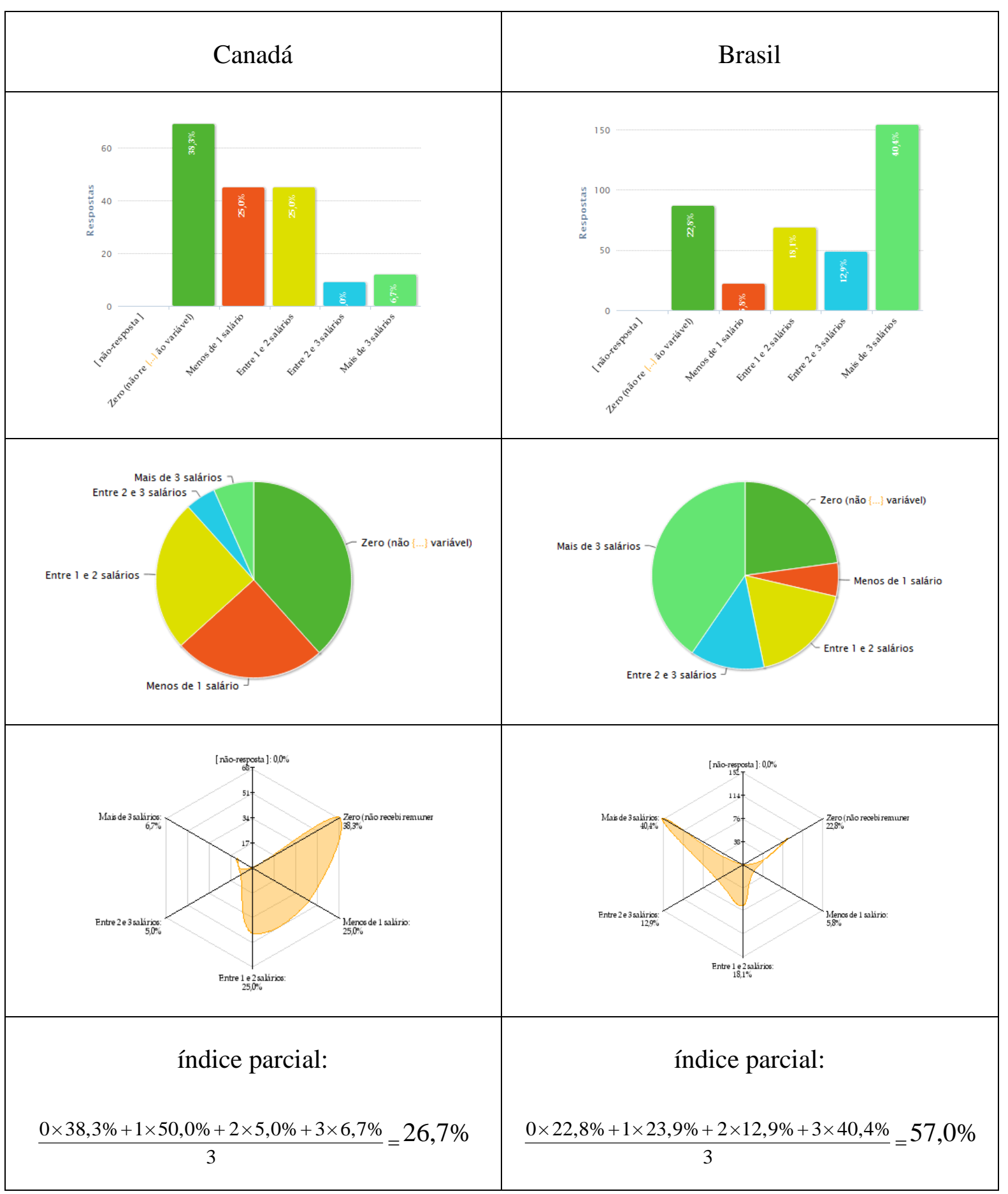

Fonte: o autor 
Temos, portanto, o seguinte resultado para o Índice do Papel Contábil:

\begin{tabular}{|l|c|c|}
\cline { 2 - 3 } \multicolumn{1}{c|}{} & Canadá & Brasil \\
\hline Índice Hierárquico: & $\frac{30,3 \%+26,7 \%}{2}=\mathbf{2 8 , 5 \%}$ & $\frac{57,5 \%+57,0 \%}{2}=\mathbf{5 7 , 3 \%}$ \\
\hline
\end{tabular}

Como se pode observar, há uma substancial vantagem de $28,8 \%$ para os respondentes do Brasil, portanto mais do que o sobro do desempenho dos respondentes do Canadá o Índice do Papel Contábil. 


\section{CONCLUSÕES}

O primeiro passo para se tirar conclusões a respeito da análise dos dados da pesquisa de campo, e por conseguinte do presente trabalho científico como um todo, consiste em organizar de forma concisa e conveniente todos os índices de gestão do capital intelectual previamente calculados, agrupados pelos aspectos básicos "Conhecimento \& Formação", "Psicossocial" e "Relações de Trabalho \& Poder".

\subsection{Aspecto básico "Conhecimento \& Formação"}

O aspecto básico "Conhecimento \& Formação" agrupa o Índice de Instrução, o Índice de Treinamento, o Índice do Sistema de Conhecimento Organizacional e o Índice Ocupacional, cada um com seu pressuposto teórico correspondente, de acordo com a teoria sobre capital intelectual estudada. O desempenho dos respondentes que declararam trabalhar no Canadá foi melhor nos dois primeiros índices, enquanto que nos outros dois índices o desempenho dos respondentes que trabalham no Brasil foi melhor, conforme a tabela a seguir: 
Tabela 16 - Comparação Geral dos Índices - Conhecimento \& Formação

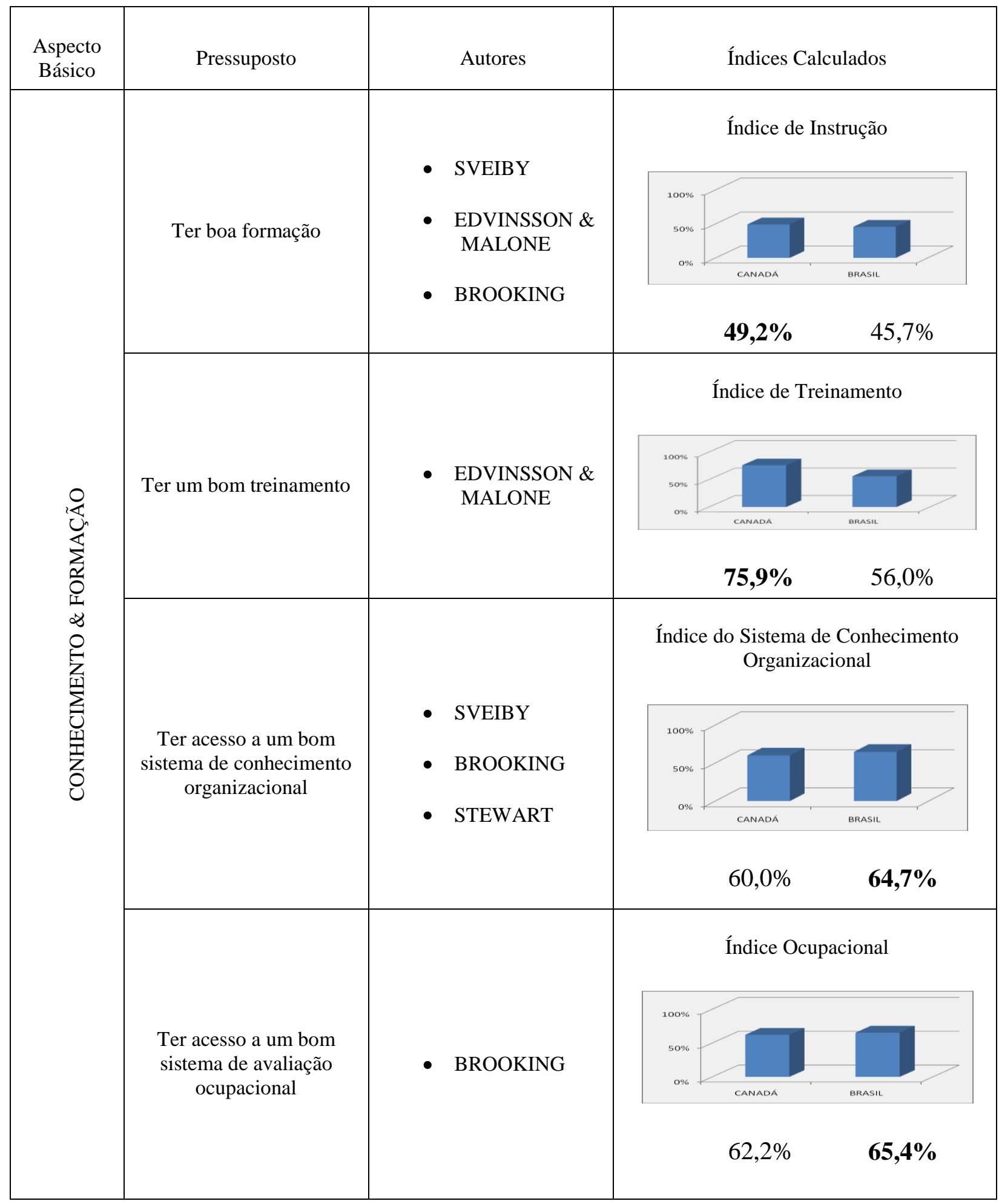


Dentre os quatro resultados acima, o mais notável é sem dúvida o resultado obtido para o Índice de Treinamento, no qual os respondentes do Canadá tiveram um desempenho 19,9\% superior aos respondentes do Brasil, enquanto que para os demais 3 índices do aspecto "Conhecimento \& Formação" as diferença entre os países foi menor que 5\%. Tal resultado leva a supor que os empregadores canadenses estão treinando melhor seus programadores que seus correspondentes brasileiros.

\subsection{Aspecto Básico "Psicossocial"}

Estão agrupados no aspecto básico "Psicossocial" outros quatro índices de capital intelectual: Índice de Satisfação, Índice Motivacional, Índice Vocacional e Índice de Coleguismo. Assim como no aspecto "Conhecimento \& Formação", houve empate entre os países, com os respondentes brasileiros tendo melhor desempenho nos dois primeiros e os canadenses nos dois últimos índices. Seguem os resultados: 
Tabela 17 - Comparação Geral dos Índices - Psicossocial

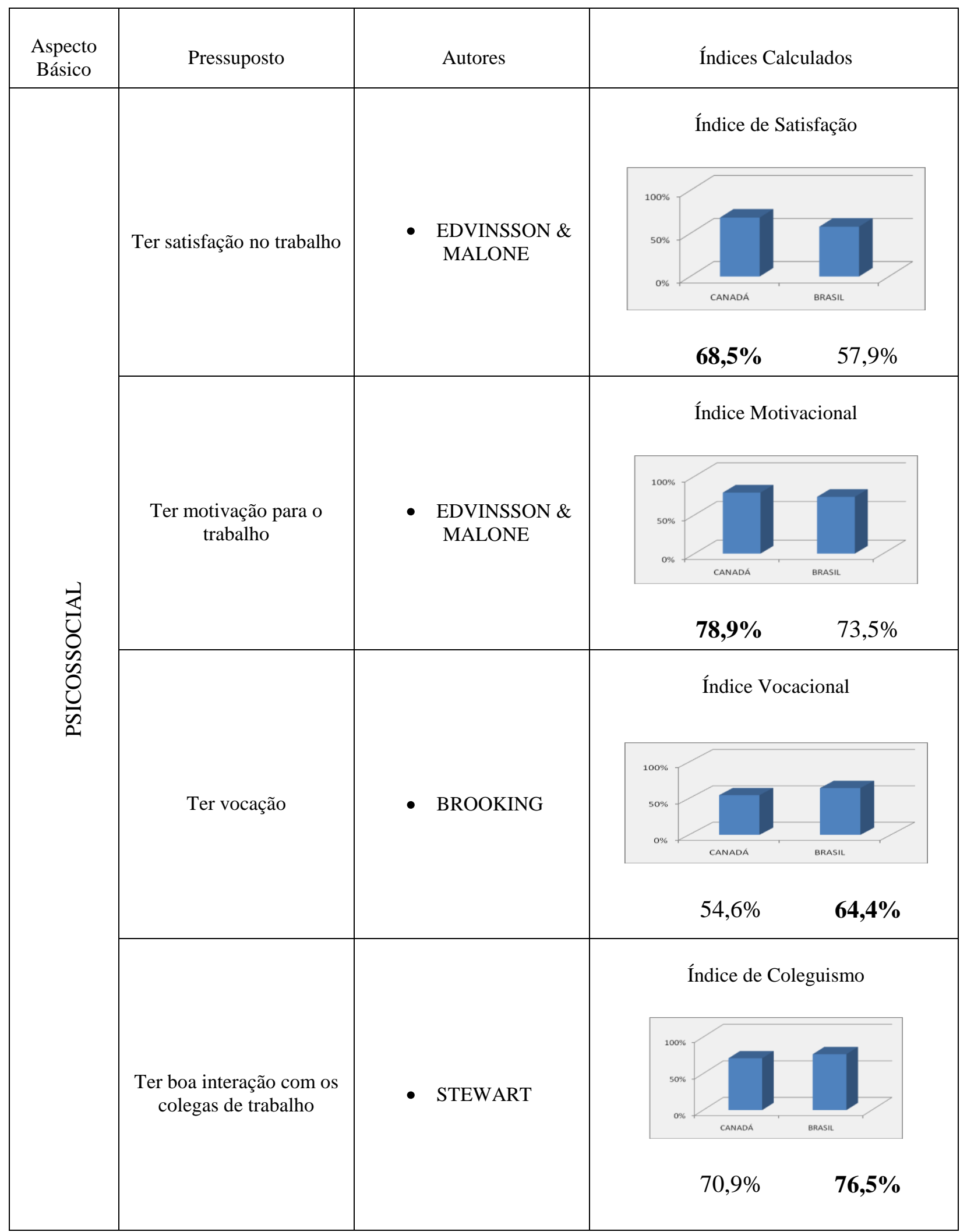


Dois resultados acima, a maior diferença foi em relação ao Índice de Satisfação, no qual os respondentes do Canadá tiveram desempenho 10,6\% maior que os respondentes do Brasil, permitindo-se supor que os programadores canadenses estão mais satisfeitos em suas atividades profissionais que os seus colegas do Brasil.

\subsection{Aspecto Básico "Relações de Trabalho \& Poder"}

O aspecto básico "Relações de Trabalho \& Poder" agrupa os cinco índices de capital intelectual restantes, ao contrário dos dois demais aspectos, que agrupam quatro índices cada. Nele, estão incluídos o Índice do Poder de Decisão (empowerment), o Índice de Contato Direto com Clientes, o Índice de Rotatividade, o Índice Hierárquico e o Índice do Papel Contábil. Seguem os resultados obtidos na pesquisa de campo: 
Tabela 18 - Comparação Geral dos Índices - Relações de Trabalho \& Poder

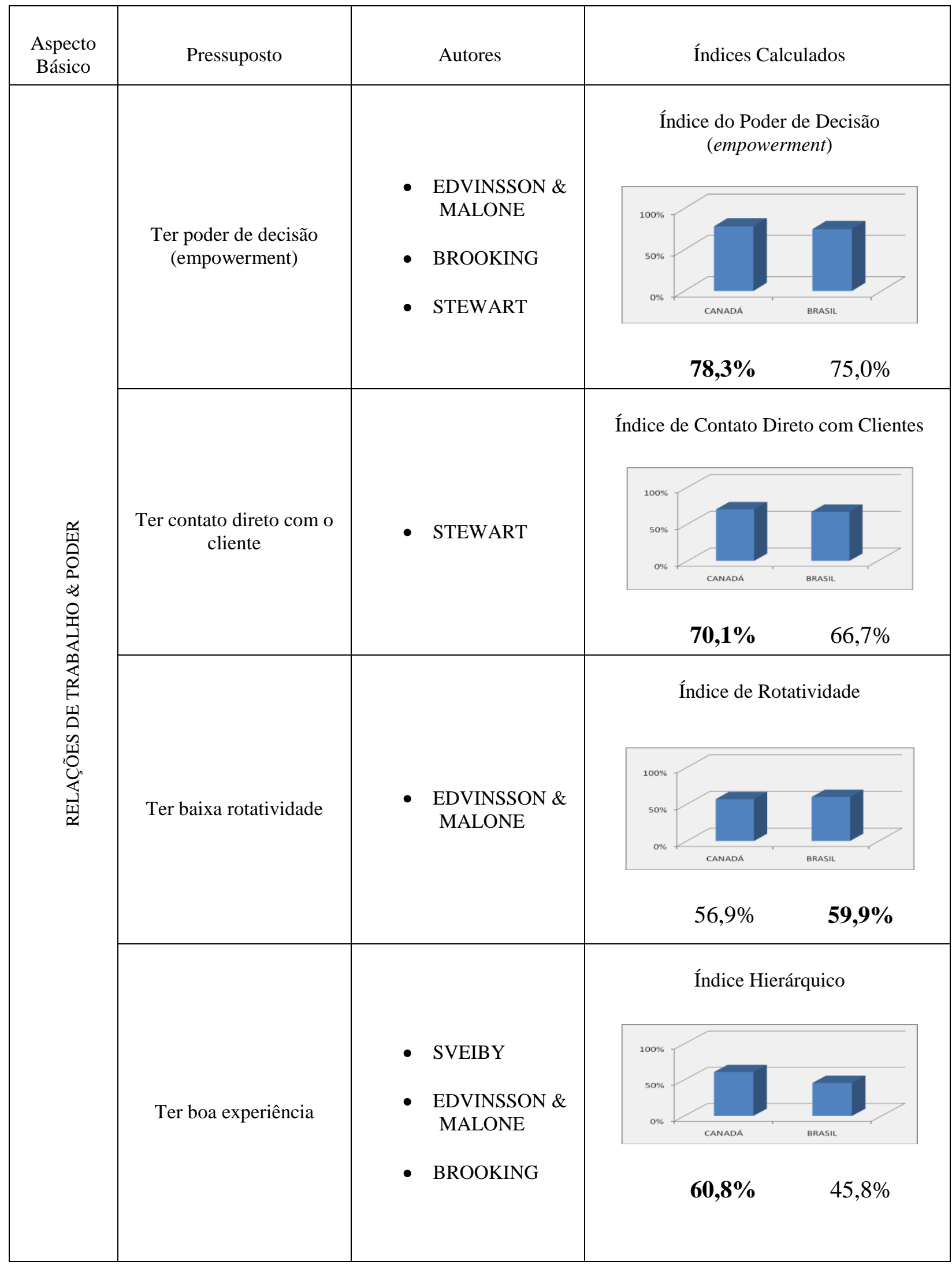




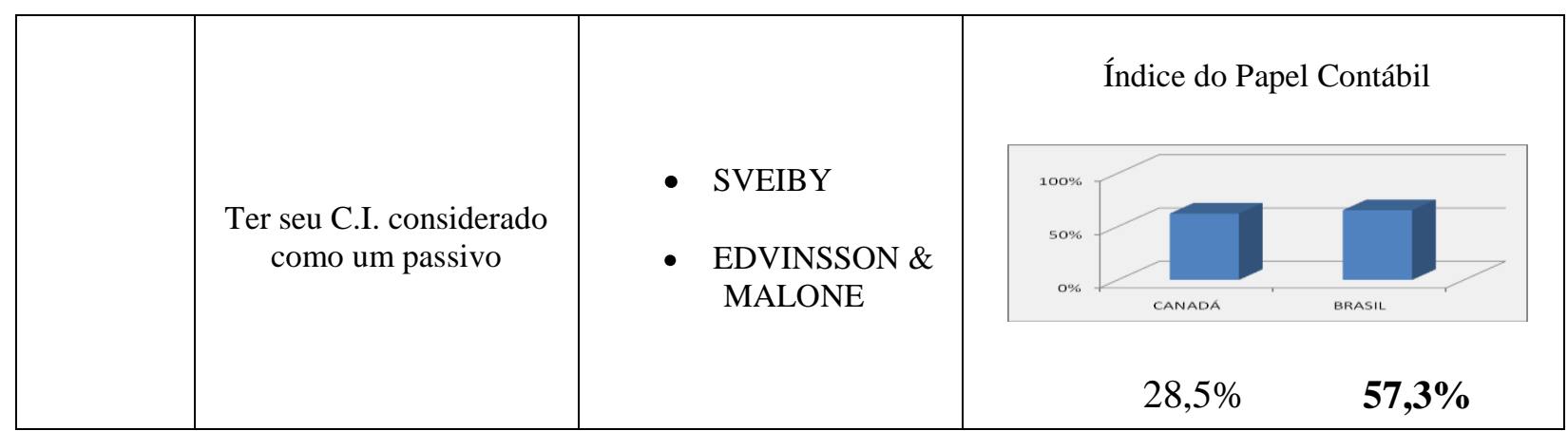

Fonte: o autor

Em dois índices houve diferença maior que $10 \%$ entre os países. No Índice Hierárquico, o desempenho dos programadores do Canadá foi 15,0\% superior, o que pode ser parcialmente explicado pela maior juventude média dos respondentes do Brasil. Já no Índice do Papel Contábil houve a maior diferença entre todos os 13 índices da pesquisa, sendo que os brasileiros obtiveram um resultado $28,8 \%$ maior que os respondentes canadenses.

A diferença expressiva no Índice do Papel Contábil e o baixo resultado de 28,5\% para os canadenses foram ambos os resultados mais extremos obtidos na pesquisa. Tais extremos levam a crer que o índice precisa ser revisto e rediscutido em um trabalho futuro, até mesmo pelas especificidades das modalidades de vínculos de trabalho vigentes em cada país, que podem ter gerado dúvidas ou mesmo confusão a partir da tradução feita para as duas questões elaboradas para investigar o pressuposto correspondente ao índice. 


\subsection{Desempenho Geral nos Índices}

Do total de 13 Índices do Capital Intelectual propostos e calculados para ambos os países, em 7 deles os respondentes do Canadá tiveram melhor desempenho, enquanto que nos 6 demais índices os respondentes do Brasil tiveram resultados melhores:

Tabela 19 - Desempenhos superiores nos Índices de Capital Intelectual, por país

\begin{tabular}{|c|c|c|}
\hline País: & Canadá & Brasil \\
\hline $\begin{array}{c}\text { Melhores } \\
\text { desempenhos: }\end{array}$ & $\begin{array}{l}\text { - Índice de Instrução } \\
\text { - Índice de Treinamento } \\
\text { - Índice de Satisfação } \\
\text { - Índice Motivacional } \\
\text { - Índice do Poder de Decisão } \\
\text { (empowerment) } \\
\text { - Índice de Contato Direto com } \\
\text { Clientes } \\
\text { Índice Hierárquico }\end{array}$ & $\begin{array}{l}\text { - Índice do Sistema de } \\
\text { - Índice Ocupacional } \\
\text { - Índice Vocacional } \\
\text { - Índice de Coleguismo } \\
\text { - Índice de Rotatividade } \\
\text { - Índice do Papel Contábil }\end{array}$ \\
\hline
\end{tabular}

Fonte: o autor

De um modo geral houve um equilíbrio entre os países, já que o Canadá superou o Brasil em apenas um índice. No aspecto básico "Conhecimento \& Formação" houve empate, com vantagem em 2 índices para ambos. O mesmo ocorreu no aspecto "Psicossocial", com 2 índices para cada, e finalmente para o aspecto básico "Relações de Trabalho \& Poder" houve vantagem para os respondentes canadenses, com 3 índices com melhor desempenho contra 2 índices com melhor desempenho para os respondente brasileiros. 


\subsection{Canadá: Melhores e Piores Desempenhos}

Do lado canadense, os 3 melhores resultados foram no Índice Motivacional (78,9\%), no Índice do Poder de Decisão (empowerment - 78,3\%) e no Índice de Treinamento (75,9\%). Por outro lado, os 3 piores resultados foram no Índice Vocacional $(54,6 \%)$, no Índice de Instrução (49,2\%) e no Índice do Papel Contábil (28,5\%).

\subsection{Brasil: Melhores e Piores Desempenhos}

Já para os respondentes brasileiros, os 3 melhores índices calculados pela metodologia proposta foram no Índice de Coleguismo (76,5\%), no Índice do Poder de Decisão (75,0\%) e no Índice Motivacional (73,5\%), enquanto que os 3 piores resultados calculados foram no Índice de Treinamento $(56,0 \%)$, no Índice Hierárquico $(45,8 \%)$ e no Índice de Instrução $(45,7 \%)$. 


\subsection{Resposta à Pergunta-Problema}

Como autor do presente trabalho, entendo que a forma mais cientificamente coerente de se responder a pergunta-problema da pesquisa é analisar o índice geral para cada aspecto básico, para cada país. Os índices gerais consistem na média aritmética dos índices calculados para cada país, e portanto podem variar de zero até $100 \%$.

\subsubsection{Conhecimento \& Formação}

Agrupa o Índice de Instrução, o Índice de Treinamento, o Índice do Sistema de Conhecimento Organizacional e o Índice Ocupacional:

\begin{tabular}{|c|c|}
\hline Canadá & Brasil \\
\hline$\frac{49,2 \%+75,9 \%+60,0 \%+62,2 \%}{4}=\mathbf{6 1 , 8 \%}$ & $\frac{45,7 \%+56,0 \%+64,7 \%+65,4 \%}{4}=\mathbf{5 8 , 0 \%}$ \\
\hline
\end{tabular}

Em relação ao aspecto básico Conhecimento \& Formação, há pequena vantagem de 3,8\% no índice geral para os canadenses, sendo que em ambas as amostras pesquisadas, as práticas de gestão do capital intelectual dos programadores estão contribuindo moderadamente para a excelência técnica e para a valorização do profissional programador.

\subsubsection{Psicossocial}

Calculado a partir do Índice de Satisfação, do Índice Motivacional, do Índice Vocacional e do Índice de Coleguismo:

\begin{tabular}{|c|c|}
\hline Canadá & Brasil \\
\hline$\frac{68,5 \%+78,9 \%+54,6 \%+70,9 \%}{4}=\mathbf{6 8 , 2} \%$ & $\frac{57,9 \%+73,5 \%+64,4 \%+76,5 \%}{4}=\mathbf{6 8 , 1 \%}$ \\
\hline
\end{tabular}


Já a respeito do aspecto básico Psicossocial, houve um quase empate entre programadores canadenses e brasileiros. Nesse aspecto do capital intelectual conclui-se também que as práticas de gestão do capital intelectual dos programadores estão contribuindo moderadamente para a excelência técnica e para a valorização do profissional programador.

\subsubsection{Relações de Trabalho \& Poder}

Inclui o Índice do Poder de Decisão, o Índice de Contato Direto com Clientes, o Índice de Rotatividade e o Índice Hierárquico:

\begin{tabular}{|c|c|}
\hline Canadá & Brasil \\
\hline$\frac{78,3 \%+70,1 \%+56,9 \%+60,8 \%+28,5 \%}{5}=\mathbf{5 8 , 9 \%}$ & $\frac{75,0 \%+66,7 \%+59,9 \%+45,9 \%+57,3 \%}{5}=\mathbf{6 1 , 0 \%}$ \\
\hline
\end{tabular}

Novamente houve resultados muito próximos entre os países pesquisados, com ligeira vantagem de 2,1\% para os respondentes do Brasil. Assim como nos dois primeiros aspectos do capital intelectual propostos, conclui-se também que, para o aspecto Relações de Trabalho \& Poder, as práticas de gestão do capital intelectual dos programadores estão contribuindo moderadamente para a excelência técnica e para a valorização do profissional programador. 


\subsection{4. Índice Geral Absoluto}

O Índice Geral Absoluto é calculado pela média ponderada de cada um dos três índices gerais calculados. A ponderação se baseia na quantidade de índices de capital intelectual que cada aspecto agrupa:

\begin{tabular}{|c|c|}
\hline Canadá & Brasil \\
\hline$\frac{4 \times 61,8 \%+4 \times 68,2 \%+5 \times 58,9 \%}{13}=\mathbf{6 2 , 7 \%}$ & $\frac{4 \times 58,0 \%+4 \times 68,1 \%+5 \times 61,0 \%}{13}=\mathbf{6 2 , 2 \%}$ \\
\hline
\end{tabular}

Apesar de haver consideráveis diferenças entre os desempenhos dos respondentes de Canadá e Brasil quando se compara cada um dos 13 índices individualmente, o cálculo dos índices gerais absolutos do capital intelectual dos programadores apontou um quase empate entre os países, com vantagem de apenas $0,5 \%$ para os respondentes canadenses, situando-se ambos os índices gerais entre o segundo e o terceiro quartis, isto é, entre $50 \%$ e $75 \%$.

A resposta global à pergunta-problema se baseia essencialmente nos resultados dos índices gerais, que como dito anteriormente variam entre zero e $100 \%$, valor este que indicaria uma gestão plena e perfeita do capital intelectual, contribuindo para a excelência técnica e para a valorização do profissional programador. Sendo assim, pelo fato de o índice geral absoluto da gestão do capital intelectual dos programadores para o Canadá ter sido de $62,7 \%$ e o do Brasil de 62,2\%, conclui-se que, em ambos os países pesquisados, as práticas de gestão do capital intelectual dos programadores estão contribuindo moderadamente para a excelência técnica e para a valorização do profissional programador. 


\section{CONSIDERAÇÕES FINAIS}

\subsection{Limitações do Estudo}

Basicamente as limitações do presente trabalho científico são a amostragem por conveniência e participação de apenas dois países. Como já exposto anteriormente, a amostragem foi feita através do método descrito nos itens 6.1.1 e 6.1.2, usando-se de serviços online de ambos os países. Utilizei de meus conhecimentos em programação de computadores para alcançar, através de mensagens de $e$-mail, todas as dezenas de milhares de instituições lá cadastradas.

Apesar da ampla e variada gama de instituições contactada, apenas uma pequena parte das pessoas se dispôs a colaborar com a pesquisa, e tal decisão de colaborar ou não é muito difusa para se determinar de forma satisfatória a significância da amostra. Apesar disso, o fato de a Internet ter a propriedade de neutralizar barreiras geográficas contribuiu imensamente para capilaridade e a internacionalização da pesquisa, constituindo assim um aspecto em prol da significância estatística da amostra coletada.

A participação de Brasil e Canadá na pesquisa foi um fator cientificamente enriquecedor pois possibilitou a comparação e a internacionalização, algo que seria impossível caso somente respondentes do Brasil participassem. Entretanto, os resultados seriam ainda mais ricos caso mais países participassem da investigação, como por exemplo a Índia, país mundialmente conhecido como grande provedor de desenvolvedores de software. 


\subsection{Sugestões para Estudos Futuros}

As sugestões para futuros estudos nas áreas de capital intelectual e de gestão do capital intelectual são um reflexo das limitações descritas acima. A inclusão de mais países e de mais áreas profissionais em um estudo semelhante seria imensamente enriquecedora, além, é claro, do aperfeiçoamento da metodologia de pesquisa como um todo, desde as perguntas formuladas ou mesmo as opções de respostas para cada uma, até mesmo a discussão mais avançada sobre os índices propostos a partir da bibliografia estudada.

Do lado da indústria de software, sugere-se maior atenção científica ao profissional programador de softwares, que é agente nuclear de toda essa fundamental atividade econômica, que certamente afeta de forma fundamental todas as instituições modernas, cada vez mais dependentes e utilizando cada vez mais intensamente a tecnologia da informação como principal ferramenta de controle de seus processos de produção. 


\section{APÊNDICES}

Apêndice 1 - Instrumento de coleta de dados em português 


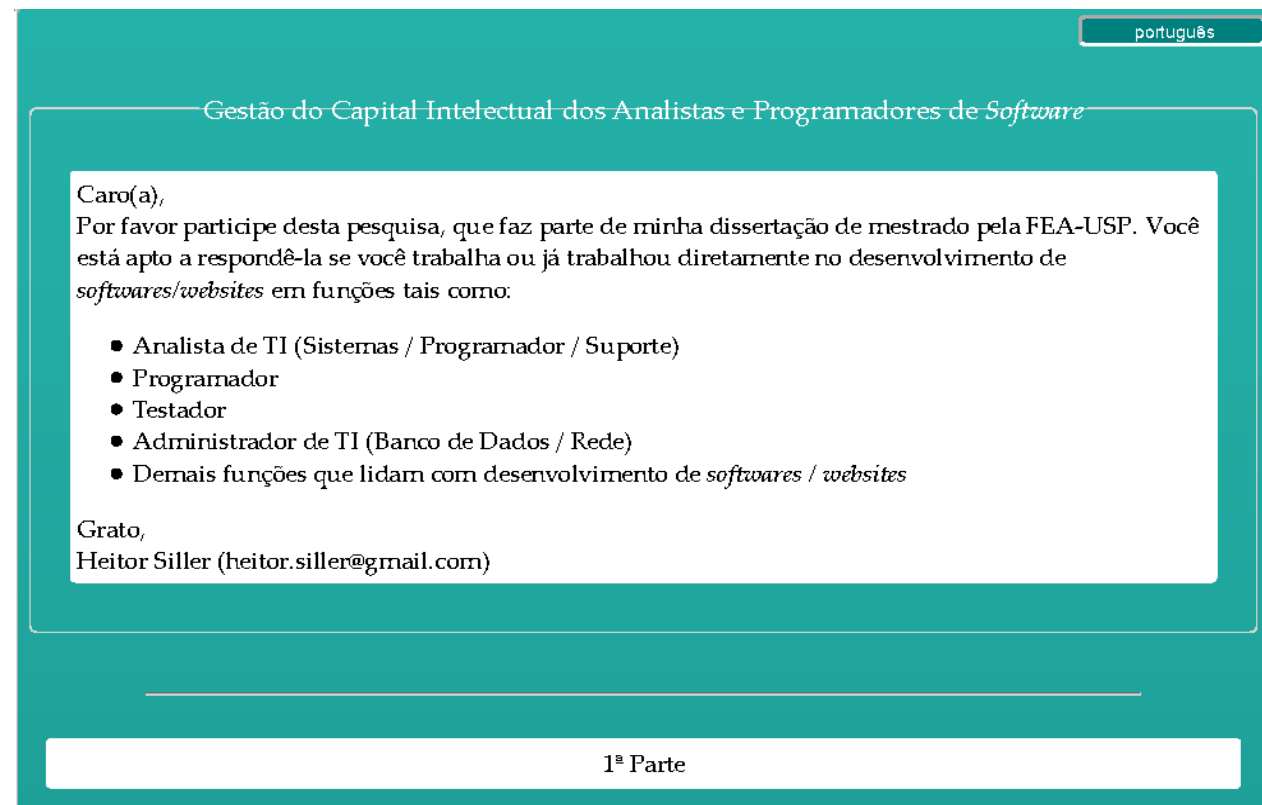

* 1 - Qual a sua escolaridade máxima?

- Ensino Fundamental (primário + ginásio) incompleto

- Ensino Fundarnental (primário + ginásio) completo

- Ensino Médio (colegial) incompleto

- Ensino Médio (colegial) completo

- Ensino Superior incompleto

- Ensino Superior completo

- MBA / Especialização incompleta

- MBA / Especialização completa

- Mestrado / Doutorado incompleto

- Mestrado / Doutorado completo

outro :

* 2 - En quantos idiomas você consegue se cornuricar satisfatoriarnente?

- Um

- Dois

- Três

- Quatro

- Cinco ou mais idiomas

*3 - Em relação ao seu último ou atual emprego:

\begin{tabular}{|c|c|c|c|}
\hline discordo & discordo & concordo & concordo \\
totalmente & parcialmente & parcialmente & totalmente \\
1 & 2 & 3 & 4 \\
\hline
\end{tabular}
A minha empresa me dá excelentes condições de treinamento/auto-aprendizado -1 para exercer minhtas funções.
Tenho pleno acesso às informações de que preciso para o desempenho de minhas 3.2 funções.
3.3 Os softwares que planejo ou desenvolvo ficarn fartarnente documentados.
${ }_{3.4}$ Estou plenamente satisfeito com as funços e atividades que exerço atualmente.
A ernoresa se oreocuna mnstanternente em me alocar em atividades nas ouais

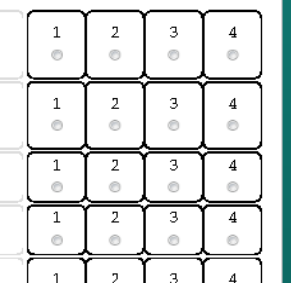


A empresa se preocupa constantemente en me alocar em atividades nas quais

3.5 tenho maior aptidão.

3.6 A minha empresa atual paga ou já pagou para eu estudar.

\begin{tabular}{|c|c|c|c|}
\hline 1 & 2 & 3 & 4 \\
\hline 0 & 0 & 0 & (2) \\
\hline 1 & 2 & 3 & 4 \\
\hline 0 & 0 & 0 & 0 \\
\hline
\end{tabular}

\section{2ミ Parte}

* 4 - Ainda em relação ao seu último ou atual emprego:

\begin{tabular}{|c|c|c|c|}
\hline $\begin{array}{c}\text { discordo } \\
\text { totalmente }\end{array}$ & $\begin{array}{c}\text { discordo } \\
\text { parcialmente }\end{array}$ & $\begin{array}{c}\text { concordo } \\
\text { parcialmente }\end{array}$ & $\begin{array}{c}\text { concordo } \\
\text { totalmente }\end{array}$ \\
1 & 2 & 3 & 4 \\
\hline
\end{tabular}

4.1 Estou plenamente satisfeito com o meu momento profissional.

4.2 Estou plenarnente satisfeito com minha remuneração atual.

4.3 Desejo muito mudar de empresa ou de profissão nos próximos 12 meses.

4.4 Procuro constantemente encontrar formas de melhorar o produto de meu trabalho.

4.5 Sempre desejei trabalhar na área em que atuo atualmente.

4.6 Costumo desenvolver softwares desvinculado do trabalho.

4.7 A relação que tenho com meus colegas de trabalho é excelente.

Participo com muita freqüência de confraternizações com meus colegas de 4.B trabalho.

\begin{tabular}{|c|c|c|c|}
\hline 1 & 2 & 3 & $\begin{array}{l}4 \\
0\end{array}$ \\
\hline 1 & 2 & 3 & 4 \\
\hline 0 & 0 & 0 & 0 \\
\hline 1 & 2 & 3 & 4 \\
\hline 0 & ○ & $\theta$ & 0 \\
\hline 1 & 2 & 3 & 4 \\
\hline 0 & 0 & 0 & 0 \\
\hline 1 & 2 & 3 & 4 \\
\hline 0 & 0 & 0 & 0 \\
\hline 1 & 2 & 3 & 4 \\
\hline 0 & O & 0 & 0 \\
\hline 1 & 2 & 3 & 4 \\
\hline 0 & 0 & 0 & 0 \\
\hline 1 & 2 & 3 & 4 \\
\hline 0 & 0 & 0 & 0 \\
\hline
\end{tabular}


$3^{\mathrm{a}}$ Parte

* 5 - Também em relação ao seu último ou atual emprego:

\begin{tabular}{|c|c|c|c|}
\hline $\begin{array}{c}\text { discordo } \\
\text { totalmente }\end{array}$ & $\begin{array}{c}\text { discordo } \\
\text { parcialmente }\end{array}$ & $\begin{array}{c}\text { concordo } \\
\text { parcialmente }\end{array}$ & $\begin{array}{c}\text { concordo } \\
\text { totalmente }\end{array}$ \\
1 & 2 & 3 & 4 \\
\hline
\end{tabular}

5.1 Terho amplo controle sobre as minhas funçōes no trabalho.

Sou constantemente consultado antes de decisões importantes acerca dos projetos 5.2 em que participo.

5.3 Comunico-me constantemente com os clientes dos projetos que participo.

5.4 Visito rotineiramente os clientes dos projetos nos quais participo.

*6-Quantos empregos você já teve como programador/analista de sistemas, contando com o atual?

Um

Dois

Três

Quatro

Cinco ou mais

*7 - Quantas vezes você já foi promovido, trabalhando como programador/analista de sistemas?

Nenhuma vez

Una vez

Duas vezes

Três vezes

Quatro ou mais vezes

* 8 - Qual é o seu rúvel técrico como programador/analista de sistemas?

Iniciante

Intermediário

- Avarçado

* 9 - Qual é o tipo de seu vínculo contratual de trabalho?

Estagiário

C.L.T.

Pessoa Juridica

Autônomo

Cooperado

Informal

outro :

* 10 - Qual foi a sua remuneração variável no ano passado? (participação nos lucros, bônus, gratificação, $14^{\circ}$ salário, etc)

Zero (não recebi remuneração variável)

Menos de 1 salário

Entre 1 e 2 salários

Entre 2 e 3 salários 
- Mais de 3 salários

* 11 - Em qual país você trabalha ou trabalhou como programador/analista de TI?

- Canadá

- Brasil

outro: 
* 12 - Qøal é a søa idade?

Menos de 18 anos

- Entre 18 e 21 anos

- Entre 22 e 30 anos

Entre 31 e 40 anos

- Entre 41 e 50 anos

- Entre 51 e 60 anos

Mais de 60 anos

* 13 - Qøal é o seø sexo?

Feminino

Masc® lino

* 14 - Qøal é o nome básico de seø atøal oø último cargo/fø nção?

- Analista de Sisternas

- Analista Progranador

- Analista de Søporte

- Programador

Testador

Adrninistrador de Banco de Dados

Administrador de Rede

- Coordenador

- Chefe de Eqøipe

Diretor

oø tro:

* 15 - Há qøanto tempo você trabalha profissionalmente como programador/analista de sistemas?

Menos de 1 ano

- Entre 1 e 2 anos

Entre 2 e 3 anos

Entre 3 e 4 anos

Entre 4 e 5 anos

- Entre 5 e 10 anos

Mais de 10 anos

* 16 -Qøal é o se® estado civil?

Solteiro(a)

- Casado(a)

Divorciado(a)

Viúvo(a)

União Estável

* 17 - Qøantos filhos(as) você têm?

Nenhø m

- Um

- Dois 


\section{Três \\ Quatro \\ - Cinco ou mais}

* 18 - Quais das linguagøns dø programação abaixo você domina?

$\square \mathrm{C} / \mathrm{C}^{++} / \mathrm{CH}$

$\square \mathrm{SQL}$

$\square$ Java

$\square \mathrm{PHP}$

$\square$ Visual Basic

$\square$ ASP

$\square$ JavaScript/Ajax

$\square$ HTML

$\square$ Ruby

- Cobol

$\square$ Dølphi/Pascal

$\square$ outro :

* 19 - Qual é a quantidadø dø programadorøs/analistas dø sistønas थn sua थnpresa atual/última?

- Somøntø um (øu møsmo)

Entrø 2 ๑5

Entrø 6 @ 10

Entrø 11 @ 20

Entrø 21 ๑50

Entrø 50 ๑100

Mais dø 100

* 20 - Qual é o tipo dø software produzido øn sua @nprøsa atual/última?

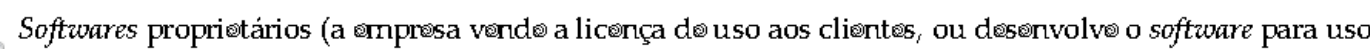
próprio)

- Softwares sob medida (a थmpresa vøndø o sørviço dø døsenvolvimento aos clientes)

- Ambos

21 - (opcional) Døixø søus comøntários. Sø døsøjar røcøbr uma cópia do trabalho final, quøira indicar søu o-mail.

ENVIAR 
Apêndice 2 - Instrumento de coleta de dados em inglês 
Dear respondent,

Please participate in this research, which is part of my dissertation from FEA-USP (Universidade de São Paulo - Brazil). You are able to answer it if you work or have worked directly in the development of software/websites in functions such as:

- IT Analyst (Systems / Programmer / Support)

- Programmer

- Tester

- IT Administrator (Database / Network)

- Other functions that deal with developing software / websites

Thanks,

Heitor Siller (heitor.siller@gmail.com)

1st Part

* 1 - What is your highest education?

Primary Education incomplete

Primary Education complete

High School Incomplete

High School complete

Graduate School Incomplete

Graduate School complete

MBA / Specialization Incomplete

- MBA / Specialization complete

Masters / Doctorate incomplete

Masters/Doctorate completed

other :

* 2 - How many languages can you communicate well?

One

c Two

c) Three

Four

Five or more languages

* 3 - Regarding your last or current job: 


\begin{tabular}{|c|c|c|c|}
\hline strongly disagree & partially disagree & partially agree & totally agree \\
1 & 2 & 3 & 4 \\
\hline
\end{tabular}

My company gives me excellent training/self-learning conditions to perform my ${ }^{3.1}$ functions.

3.2 My current company pays or has paid for me to study.

3.3 I widely document the softwares I develop

3.4 I am fully satisfied with the functions and activities that I perform today.

The company worries constantly on allocating me in activities in which I have 3.5 better skills.

3.6 I have full access to the information they need to perform my duties.

\begin{tabular}{|c|c|c|c|c|}
\hline 1 & 2 & 3 & 4 \\
\hline 0 & 6 & 6 & 6 \\
\hline 1 & 2 & 3 & 4 \\
\hline 0 & 0 & 0 & 0 \\
\hline 1 & 2 & 3 & 4 \\
\hline 0 & 0 & 0 & 0 \\
\hline 1 & 2 & 3 & 4 \\
\hline 0 & 0 & 0 & 0 \\
\hline 1 & 2 & 3 & 4 \\
\hline 0 & 0 & 0 & 0 \\
\hline 1 & 2 & 3 & 4 \\
\hline
\end{tabular}

2dn Part

* 4 - Also with regard to your last or current job:

\begin{tabular}{|c|c|c|c|}
\hline strongly disagree & partially disagree & partially agree & totally agree \\
1 & 2 & 3 & 4 \\
\hline
\end{tabular}

${ }_{4.1}$ I am fully satisfied with my professional moment.

$\$ .2$ I am fully satisfied with my current remuneration.

$₫ .3$ I very much desire to change my company or occupation in the next 12 months.

${ }_{4.4}$ I consistently find ways to improve my work's product.

4.5 I always wanted to work in the area where I work today.

4.6 I have the habit of developing software not related to the job.

4.7 The relationship I have with my fellow employees is excellent.

$\$ .8$ I participate frequently in social gatherings with my fellow employees.

\begin{tabular}{|c|c|c|c|}
\hline 1 & C & ${ }^{3}$ & $\begin{array}{l}4 \\
\text { C }\end{array}$ \\
\hline $\begin{array}{l}1 \\
0\end{array}$ & ${ }^{2}$ & ${ }^{3}$ & $\begin{array}{l}4 \\
\text { C }\end{array}$ \\
\hline 1 & ${ }^{2}$ & ${ }^{3}$ & ${ }^{4}$ \\
\hline 1 & ${ }^{2}$ & ${ }^{3}$ & $\stackrel{4}{C}$ \\
\hline$\frac{1}{0}$ & ${ }^{2}$ & $\frac{3}{5}$ & $\stackrel{4}{C}$ \\
\hline $\begin{array}{l}1 \\
0\end{array}$ & c & ${ }^{3}$ & ${ }^{4}$ \\
\hline 1 & ${ }^{2}$ & ${ }^{3}$ & $\stackrel{4}{6}$ \\
\hline$\frac{1}{6}$ & $\begin{array}{l}{ }^{2} \\
\mathrm{C}\end{array}$ & ${ }^{3}$ & ${ }^{4}$ \\
\hline
\end{tabular}


* 5 - Also in relation to your last or current job:

\begin{tabular}{|c|c|c|c|}
\hline strongly disagree & partially disagree & partially agree & totally agree \\
1 & 2 & 3 & 4 \\
\hline
\end{tabular}

5.1 I have full control over my duties at work.

I am constantly consulted before important decisions about the projects in which ${ }^{5.2}$ I participate.

I constantly communicate with the customers of the projects in which I 5.3 participate.

${ }_{5.4}$ I frequently visit the customers of the projects in which I participate.

\begin{tabular}{|c|c|c|c|}
\hline 1 & 2 & 3 & 4 \\
\hline & 6 & 6 & 6 \\
\hline 1 & 2 & 3 & 4 \\
\hline & 0 & 6 & 6 \\
\hline 1 & 2 & 3 & 4 \\
\hline 6 & 6 & 6 & 6 \\
\hline 1 & 2 & 3 & 4 \\
\hline
\end{tabular}

* 6 - How many jobs have you had as a programmer/systems analyst, including the current?

\begin{tabular}{|l|l|}
\hline One \\
\hline & Two \\
\hline & Three \\
\hline & Four \\
\hline & Five or more \\
\hline
\end{tabular}

* 7 - How many times have you been promoted, working as a programmer / systems analyst?

Not once

Once

Twice

Thrice

Four or more times

* 8 - What is your skill level as a programmer / systems analyst?

Beginner

Intermediate

Advanced

* 9 - What kind of employment contract do you have?

Trainee

$\checkmark$ Registered

Corporate 
Autonomous

Cooperative

Informal

other:

* 10 - What was your variable pay last year? (profit sharing, bonus, gratuity, 14 th salary, etc.)

Zero (I did not receive variable remuneration)

Less than a salary

Between 1 and 2 salaries

Between 2 and 3 salaries

$\checkmark$ More than 3 salaries

* 11 - In which country do you work or worked as an IT programmer / analyst?

Canada

Brazil

other: 
12 - What is your age?

Less than 18 years

Between 18 and 21 years

Between 22 and 30 years

Between 31 and 40 years

Between 41 and 50 years

Between 51 and 60 years

More than 60 years

* 13 - What is your gender?

Female

Male

* 14 - What is the base name of your current or last position/function?

Systems Analyst

Analyst Programmer

Support Analyst

Programmer

Tester

Database Administrator

Network Administrator

Coordinator

Team Leader

- Director

other :

${ }^{*} 15$ - How long have you worked professionally as a programmer / systems analyst?

Less than 1 year

Between 1 and 2 years

Between 2 and 3 years

Between 3 and 4 years

Between 4 and 5 years

Between 5 and 10 years

C More than 10 years

* 16 - What is your marital status? 
Single

Married

Divorced

$c$ Widower

Common-law

* 17 - How many children you have?

\begin{tabular}{|l|l|}
\hline & Zero \\
\hline & One \\
\hline Two \\
\hline & Three \\
\hline & Four \\
\hline & Five or more \\
\hline
\end{tabular}

${ }^{*} 18$ - Which of the following programming languages you have mastered?

$\Gamma \mathrm{C} / \mathrm{C}++\mathrm{CH}$

$\Gamma$ SQL

$\Gamma$ Java

$\ulcorner$ PHP

$\Gamma$ Visual Basic

$\ulcorner$ ASP

$\ulcorner$ JavaScript/Ajax

$\ulcorner$ HTML

$\ulcorner$ Ruby

$\ulcorner$ Cobol

$\ulcorner$ Delphi/Pascal

$\ulcorner$ other :Г

${ }^{*} 19$ - What is the amount of programmers/systems analysts in your company's current/last?

Only one (myself)

Between 2 and 5

Between 6 and 10

Between 11 and 20

Between 21 and 50

Between 50 and 100

More than 100

*20 - What kind of software is produced in your current/last company?

Proprietary software (the company sells to the clients the software's user license, or developes the software for its own use) 
$\checkmark$ Custom software (the company sells the service of software development to clients)

Both

21 - (optional) Leave your comments. If you wish to receive a copy of the final survey (in Portuguese), please provide your e-mail.

SUBMIT 
Apêndice 1 - Instrumento de coleta de dados em francês 


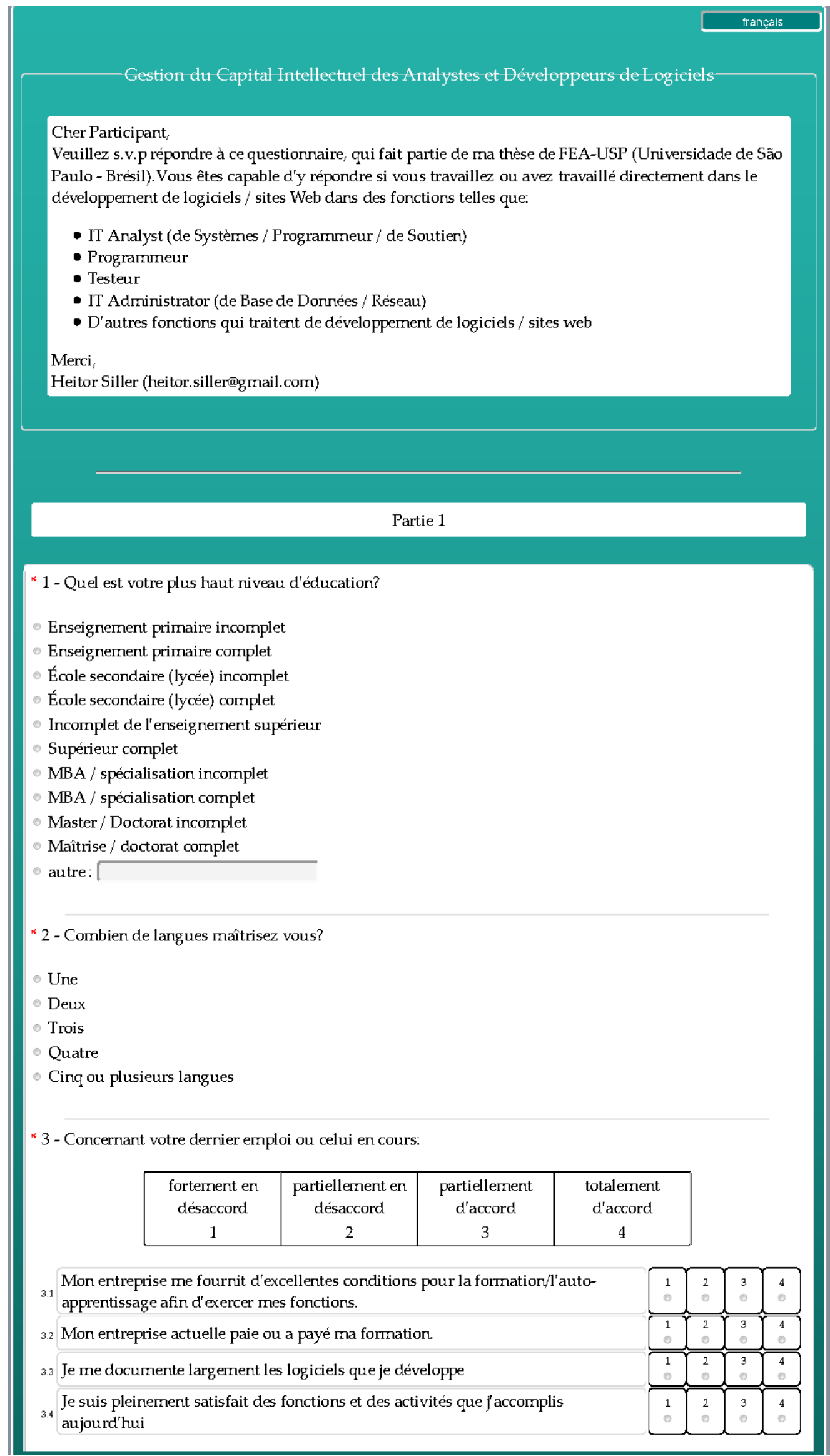


L'entreprise se préoccuppe constannent à m'orienter vers des activités pour

${ }^{3.5}$ lesquelles j'ai le plus d'aptitudes

J'ai un accès complet aux informations dont (ils ont) j'ai besoin pour exercer mes

${ }^{3.6}$ fonctions

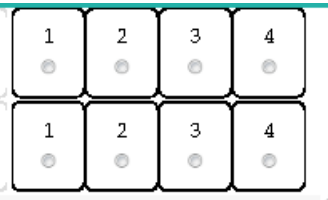

Partie 2

* 4 - Toujours à propos de votre dernier emploi ou celui en cours:

\begin{tabular}{|c|c|c|c|}
\hline $\begin{array}{c}\text { fortement en } \\
\text { désaccord }\end{array}$ & $\begin{array}{c}\text { partiellement en } \\
\text { désaccord }\end{array}$ & $\begin{array}{c}\text { partiellement } \\
\text { d'accord }\end{array}$ & $\begin{array}{c}\text { totalement } \\
\text { d'accord }\end{array}$ \\
1 & 2 & 3 & 4 \\
\hline
\end{tabular}

4.1 Je suis pleinement satisfait de ma situation professionnelle.

4.2 Je suis pleinement satisfait de ma rémunération actuelle.

J'ai très envie de changer de compagnie ou de profession au cours des 12 prochains

4.3 mois.

4.4 Je trouve toujours des façons d'améliorer le produit de mon travail

Vous avez toujours voulu travailler dans le domaine où vous travaillez 4.5 aujourd'hui.

4.6 J' ai l'habitude de développer des logiciels non liés à mon emploi

4.7 La relation que j'ai avec mes collègues de travail est excellente.

Je participe fréquemment à des rassemblements sociaux avec mes collègues de

4.B travail.

\begin{tabular}{|c|c|c|c|}
\hline $\begin{array}{l}1 \\
0\end{array}$ & 2 & $\begin{array}{l}3 \\
0\end{array}$ & $\begin{array}{l}4 \\
0\end{array}$ \\
\hline 1 & 2 & 3 & 4 \\
\hline 0 & 0 & (2) & 0 \\
\hline 1 & 2 & 3 & 4 \\
\hline 0 & 0 & 0 & 0 \\
\hline 1 & 2 & 3 & 4 \\
\hline 0 & 0 & 0 & 0 \\
\hline 1 & 2 & 3 & 4 \\
\hline 0 & 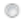 & 0 & 0 \\
\hline 1 & 2 & 3 & 4 \\
\hline 0 & 0 & 0 & 0 \\
\hline 1 & 2 & 3 & 4 \\
\hline 0 & 0 & 0 & 0 \\
\hline 1 & 2 & 3 & 4 \\
\hline 0 & 0 & 0 & 0 \\
\hline
\end{tabular}


Partie 3

* 5 - Toujours en rapport à votre derrier emploi ou celui en cours:

\begin{tabular}{|c|c|c|c|}
\hline $\begin{array}{c}\text { forternent en } \\
\text { désaccord }\end{array}$ & $\begin{array}{c}\text { partiellement en } \\
\text { désaccord }\end{array}$ & $\begin{array}{c}\text { partiellement } \\
\text { d'accord }\end{array}$ & $\begin{array}{c}\text { totalement } \\
\text { d'accord }\end{array}$ \\
1 & 2 & 3 & 4 \\
\hline
\end{tabular}

5.1 J'ai le plein contrôle sur mes tâches au travail

Je suis constanment consulté avant que des décisions importantes soient prises sur 5.2 les projets auxquels je participe.

5.3 Je communique constamment avec les clients des projets auxquels je participe.

5.4 Je visite régulièrement les clients des projets auxquels je participe.

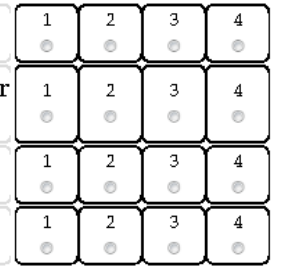

*6 - Combien d'emplois avez-vous eu en tant que progranmeur/analyste de systènes, incluant l'emploi actuel?

- Un

- Deux

- Trois

- Quatre

- Cinq ou plus

* 7 - Combien de fois avez-vous été promu, en travaillant en tant que programmeur / analyste de systèrnes?

- Aucune fois

- Une fois

- Deux fois

- Trois fois

- Quatre fois ou plus

* 8 - Quel est votre niveau de compétence en tant que programmeur / analyste de systèmes?

- Débutant

Intermédiaire

- Avancée

*9 - Quel genre de contrat de travail possédez vous?

- Stagiaire

- Enregistré

- Entreprise

- Autonome

- Coopérative

- Informelle

o autre:

* 10 - Quel était votre salaire variable l'an dernier? (intéressement, bonus, gratifications, 14èrne salaire, etc)

- Zéro (je r'ai pas reçu de rérnunération variable)

- Moirs d'un salaire

- Entre 1 et 2 des salaires

- Entre 2 et 3 des salaires 


\section{Plus de 3 salaires}

* 11 - Dans quel pays travaillez vous (ou avez travaillé) comme programmeur / analyste de TI?

- Canada

- Brésil

- autre: 
* 12 - Quel est votre âge?

- Moins de 18 ans

- Entre 18 et 21 ans

Entre 22 et 30 ans

- Entre 31 et 40 ans

Entre 41 et 50 ans

Entre 51 et 60 ans

Plus de 60 ans

$* 13$ - Quel est votre sexe?

- Fernme

Homme

* 14 - Quel est le nom de base de votre actuelle ou derrière position/fonction?

- Analyste de Systèrnes

- Analyste Prograrnmeur

- Analyste de Soutien

- Programmeur

- Testeur

- Adrninistrateur de Base de Données

- Administrateur Réseau

- Coordonnateur

- Chef d'équipe

- Directeur

$\circ$ autre:

* 15 - Combien de temps avez-vous travaillé en tant que progranneur /analyste de systèrnes?

- Moins d'1 an

- Entre 1 et 2 ans

- Entre 2 et 3 ans

Entre 3 et 4 ans

- Entre 4 et 5 ans

- Entre 5 et 10 ans

- Plus de 10 ans

* 16 - Quel est votre statut matrimonial?

- Celibataire

- Marié (a)

- Divorcé (a)

- Veuf(ve)

Conjoint de Fait

* 17 - Combien d'enfants avez-vous?

- Aucun

- Une

- Deux 

- Trois
- Quatre
- Cinq ou plus

* 18 - Lequel de ces langages de programmation suivants maîtrisez vous?
$\mathrm{C} / \mathrm{C}++/ \mathrm{CH}$
$\square \mathrm{SQL}$
$\square$ Java
$\square$ PHP
- Visual Basic
$\square$ ASP
- JavaScript/Ajax
๑ HTML
$\checkmark$ Ruby
$\square$ Cobol
$\square$ Delphi/Pascal
$\square$ autre:

* 19 - Combien de programmeurs/analystes de systèmes y a-t-il dans votre entreprise actuelle/dernière?

- Seulement un (moi)

- Entre 2 et 5

- Entre 6 et 10

- Entre 11 et 20

- Entre 21 et 50

- Entre 50 et 100

- Plus de 100

*20 - Quel genre de logiciel est produit dans votre entreprise actuelle/dernière?

Les logiciels propriétaires (l'entreprise vend la licence d'utilisation du logiciel aux clients, ou le développe pour son propre usage)

- Logiciels sur mesure (l'entreprise vend aux ses clients le service de développernent des logiciels)

- Les deux

21 - (facultatif) Laissez vos commentaires. Si vous souhaitez recevoir une copie de la thèse (en portugais), veuillez indiquer votre adresse e-mail.

\section{ENVOYER}




\section{REFERÊNCIAS BIBLIOGRÁFICAS}

ADAMS, J. S. Inequity in Social Exchanges in Berkowitz, L. Advances in Experimental Social Psychology, 1965

ALDERFER, C. P. An Empirical Test of a New Theory of Human Needs, in Organizational Behavior and Human Performance, 1969

ANTUNES, Ricardo e BRAGA, Ruy - Infoproletários: Degradação Real do Trabalho Virtual

ARNOLD, H. J. A Test of the Multiplicative Hypothesis of Expectancy-Valence Theories of Work Motivation, Academy if Management Journal. Abril de 1981

ARTHUR, Lowell Jay - Produtividade do programador: um guia para gerentes, analistas e programadores.

ATKINSON, J. W. e RAYNOR, J. O. Motivation and Achievement, 1974

BOHL, M Guia para programadores.

BOUNFOUR, Ahmed The Management of Intangibles. Routledge - 2003

BRASIL. Ministério da Ciência e Tecnologia. Secretaria de Política de Informática e Tecnologia Tecnologia da informação : Programa Brasileiro da Qualidade e Produtividade em Software Brasília : MCT, 2004

BROOKING, A. - Intellectual Capital - 1997

BROOKS, F. - No Silver Bullets - IEEE Computer - 1987

CASTELLS, Manuel A Sociedade em Rede - $11^{\text {a }}$ edição - 2008

CASTILLO, Juan José O Trabalho do conhecimento na sociedade da informação in 
CASTON, R. J. e BRAITO, R. A Specification Issue in Job Satisfaction Research, Sociological Perspectives, 1985

CHANLAT, Jean-François, coord $\mathbf{O}$ indivíduo na organização : dimensões esquecidas São Paulo : Atlas, 1996

CHWAB, D. P. e CUMMINGS, L. L. Theory of Performance and Satisfaction: A Review, Industrial Relations, 1970

CORDY, Michael Systems in Business - 1990

DE FARIA, J. H. - Gestão Participativa - 2009

DE MARCO, T. e LISTER, T. - Peopleware - 1999

DECI, E. L. Intrinsic Motivation, 1975

DECI, E. L., BETLY, G., KAHLE, J., ABRAMS, L. e PORAC, J. When Trying to Win: Competition and Intrinsic Motivation, Personality and Social Psychology Bulletin, 1981

DRUCKER, Peter F. - A Nova Era da Administração - 1992

DRUCKER, Peter F. - Sociedade Pós Capitalista - 4ª edição - 1995

EARley, P. C., WOJNaroski, P. e PREST, W. Task Planning and Energy Expended: Exploration of How Goals Influence Performance, Journal of Applied Psychology, fevereiro de 1987

EDERSHEIM, Elizabeth Haas A Essência de Peter Drucker - 2007

EDVINSSON, L. e MALONE, M. S. - Capital Intelectual. Makron Books - 1997

FLEURY, Maria Tereza e colaboradores. As Pessoas na Organização. São Paulo, Editora Gente, 2002.

FORD, N. - The Productive Programmer - 2008 
FRANCISCHINI, Paulino Indicadores de produtividade na indústria de software Niterói : UFF/TEP, 1998

GOODMAN, P. S. An Examination of Referents Used in the Evaluation of Pay, Organizational Behavior and Human Performance, outubro de 1974

HEHN, H. F. - Peopleware - 1999

HENEMAN III, H. G., SCHWAB, D. P. Evaluation of Research on Expectancy Theory Prediction of Employee Performance, Psychological Bulletin, julho de 1972 HERZBERG, F. MAUSNER, B. e SNYDERMAN, B. The Motivation to Work, 1959

HOARE, C. A. R. - Proceedings of the 2nd NATO Conference on Software Engineering - 1970

HOUSE, R. J. e WIGDOR, L. A. Herzberg's Dual-Factor Theory of Job Satisfaction and Motivations: A Review of The Evidence and Criticism, 1967

HUNT, A. e THOMAS, D - The Pragmatic Programmer - 2000

JORDAN, P. C. Effects of an Extrinsic Reward on Intrinsic Motivation: A Field Experiment, Academy of Management Journal, 1986

KOMAKI, J. L. COOMBS, T., SCHEPMAN, S. Motivational Implications of Reinforcement Theory in Steers, R. M., Porter, L. W., Bigley, G. Motivation and Work Behavior, 1996

LAMMERS, Susan M. Programmers at work: interviews with 19 programmers who shaped the computer industry / Susan Lammers.

LANDY, Frank J. e BECKER, Wendy S. Motivation Theory Reconsidered, in Cummings, L. L. e Staw, B. M. "Research in Organitional Behavior”, vol. 9, 1987

LOCKE, E. A. Latham vs. Komaki: A Tale of Two Paradigms, Journal of Applied Psychology, fevereiro de 1980 
LOCKE, E. A. Toward a Theory of Task Motivation and Incentives, Organizational Behavior and Human Performance, maio de 1968

MASLOW, A. Motivation and Personality, 1954

MCGREGOR, D. The Human Side of Enterprise, 1960

MCLELLAND, D. C. POWER: The Inner Experience, 1975

MCLELLAND, D. C. The Achieving Society, 1961

MITCHELL, T. R. Expectancy Models of Job Satisfaction, Occupational Preference and Effort: A Theoretical, Methodological and Empirical Appraisal, Psychology Bulletin, novembro de 1974

NOGUEIRA, A. M. Competências em Relações de Trabalho e Sindicais in Competências - Conceitos, Métodos e Experiências - 2008

PARKER, D. F. e DYER, L. Expectancy Theory as a Within-Person Behavioral Choice Model: An Empirical Test of Some Conceptual and Methodological Refinements, Organizational Behavior and Human Performance, outubro de 1976

PORTER, L. W. e LAWLER III, E. E. Managerial Attitudes and Performance, 1968

PRITCHARD, R. D. CAMPBELL, K. M. e CAMPBELL, D. J. Effects of Extrinsic Financial Rewards on Intrinsic Motivation, Journal of Applied Psichology, 1977

REINHARTH, L. e WAHBA, M. A. Expectancy Theory as a Predictor of Work Motivation, Effort Expenditure, and Job Performance, Academy of Management Journal, setembro de 1975

RIBEIRO, R M S. Vivencia del trabajador y la organizacion del trabajo en un ambiente de alta tecnologia In: Revista Interamericana de Psicologia, v.13, n.2 , p.13744, 1994

RICH, C. e WATERS, R. C. - The Programmer's Apprentice - 1990 
ROBBINS, Stephen P. Comportamento Organizacional. São Paulo, Pearson Prentice Hall - $11^{\mathrm{a}}$. edição -2005.

ROCHA, Ricardo Luis de Azevedo da Gerenciando a produção de software : uma experiência São Paulo, 1994

RONEN, S. Equity Perception in Multiple Comparisons: A Field Study, Human Relations, abril de 1986

RUHL, Janet The Programmer's Survival Guide - 1989

SANTOS, Sergio Luiz dos Fatores de suporte ao aumento da produtividade da tecnologia da informação Ponta Grossa, 2005

SCHOLL, R. W., COOPER, E. A., MCKENNA, J. F. Referent Selection in Determining Equity Perception: Differential Effects on Behavioral and Attitudinal Outcomes, Personnal Psychology, 1987

SCHROF, J. M. Tarnished Trophies, U.S. News \& World Report, 1993

SOFTEX Software e Serviços de TI - A Indústria Brasileira em Perspectiva - 2009

STAHL, M. J. Managerial and Technical Motivation: Assessing Needs for Achievement, Power and Affiliation, 1986

STAIR, Ralph M. e REYNOLDS, George W. - Princípios de Sistemas de Informação - $6^{\text {a }}$ edição - 2009

STEWART, T. A. Capital Intelectual. Campus $-8^{\text {a }}$ edição -1998

STEWART, T. A. The Wealth of Knowledge. Currency - 2001

SUMMERS, R. J. e CRONSHAW, S. F. A Study of McGregor's Theory X, Theory Y and the influence of Theory X, Theory Y Assumptions on Causal Attributions for Instances of Worker Poor Performance, in McShane, S. L. Organizational Behavior, 1988 
SUMMERS, T. P., DENISI, A. S. In Search Of Adams' Other: Reexamination of Referents Used In The Evaluation of Pay, Human Relations, Junho De 1990

SVEIBY, K. E. - The New Organizational Wealth. San Francisco - 1997

TEECE, D. J. - Managing Intellectual Capital. Oxford - 2000

UNPAN - United Nations Public Administration Network - disponível em www.unpan.org - acesso em 10/06/2011

VAN ERDE, W. e THIERRY, H. Vroom Expectancy Models and Work-Related Criteria: A Meta-Analysis, Journal of Applied Psychology, outubro de 1996

VROOM, V. H. Work and Motivation, 1964

WEINBERG, Gerald M. - The Psychology of Computer Programming - 1971

YOURDON, E. N. - Administrando o Ciclo de Vida do Sistema - 1989

YOURDON, E. N. - Classics in Software Enginnering - 1979

YOURDON, Edward - Declínio e queda dos analistas e dos programadores. - 1995

YOURDON, Edward - Ressurreição e ascensão dos analistas e dos programadores. 1997

ZAVATTARO, Hely Aparecida - A qualidade de vida no trabalho de profissionais da área de informática. 